UNIVERSIDADE DE SÃO PAULO

FACULDADE DE FILOSOFIA, LETRAS E CIÊNCIAS HUMANAS

DEPARTAMENTO DE LINGUÍSTICA

PROGRAMA DE PÓS-GRADUAÇÃO EM SEMIÓTICA E LINGUÍSTICA GERAL

LUCAS CAVALINI BARBOZA

\title{
Aspectos da glotalização na língua Dâw: um estudo de fonética experimental
}



UNIVERSIDADE DE SÃO PAULO

FACULDADE DE FILOSOFIA, LETRAS E CIÊNCIAS HUMANAS

DEPARTAMENTO DE LINGUÍSTICA

PROGRAMA DE PÓS-GRADUAÇÃO EM SEMIÓTICA E LINGUÍSTICA GERAL

LUCAS CAVALINI BARBOZA

\section{Aspectos da glotalização na língua Dâw: um estudo de fonética experimental}

Dissertação de mestrado apresentada ao Programa de Pós-Graduação em Semiótica e Linguística Geral da Faculdade de Filosofia, Letras e Ciências Humanas da Universidade de São Paulo, para a obtenção do título de Mestre em Letras.

Área de concentração: Semiótica e Linguística Geral

Orientadora: Prof ${ }^{a}$. Dr ${ }^{\text {a }}$. Luciana Raccanello Storto

São Paulo 
Autorizo a reprodução e divulgação total ou parcial deste trabalho, por qualquer meio convencional ou eletrônico, para fins de estudo e pesquisa, desde que citada a fonte.

Catalogação na Publicação

Serviço de Biblioteca e Documentação

Faculdade de Filosofia, Letras e Ciências Humanas da Universidade de São Paulo

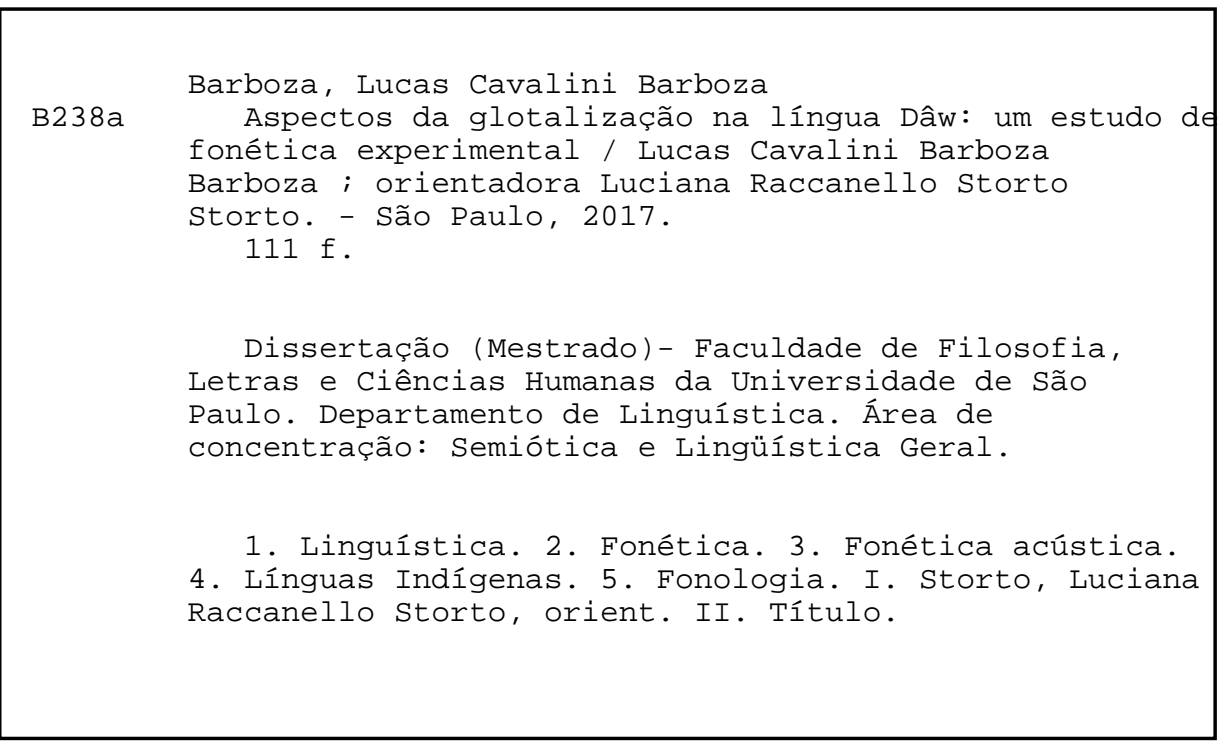


Lucas Cavalini Barboza

\section{Aspectos da glotalização na língua Dâw: um estudo de fonética experimental}

Dissertação de mestrado apresentada ao Programa de Pós-Graduação em Semiótica e Linguística Geral da Faculdade de Filosofia, Letras e Ciências Humanas da Universidade de São Paulo, para a obtenção do título de Mestre em Letras.

Área de concentração: Semiótica e Linguística Geral

Aprovado em: São Paulo,

Prof $^{\text {a }}$. Dr ${ }^{\text {a }}$. Luciana Raccanello Storto

Orientadora

Prof $^{\mathrm{a}}$. Dra . Beatriz Raposo de Medeiros

Titular

Prof $^{\mathrm{a}}$. Dra . Eleonora Cavalcante Albano

Titular

Prof $^{\mathrm{a}}$. Dra . Gessiane Lobato Picanço

Titular

Prof. ${ }^{\text {a }}$ Dr. ${ }^{\text {a }}$ Maria Filomena Spatti Sândalo

Suplente

Prof. Dr. Paulo Chagas de Sousa

Suplente

Prof. Dr. Plínio Almeida Barbosa

Suplente 

Ao povo Dâw.

Aos meus pais, Anselmo e Rosana.

À minha companheira amada, Lívia. 



\section{Agradecimentos}

Agradeço à Fundação de Amparo à Pesquisa do Estado de São Paulo (FAPESP) ${ }^{1}$ e ao Conselho Nacional de Desenvolvimento Científico e Tecnológico $(\mathrm{CNPq})^{2}$ pela concessão das bolsas de mestrado e pelo financiamento da pesquisa, que foram imprescindíveis para o desenvolvimento e a conclusão deste trabalho. À Universidade de São Paulo (USP) e à Faculdade de Filosofia, Letras e Ciências Humanas (FFLCH), pela oportunidade em cursar a graduação em Letras (Português e Linguística), entre 2010 e 2014, e a pós-graduação em Semiótica e Linguística Geral, entre 2015 e 2017.

À minha orientadora, a Prof ${ }^{\mathrm{a}}$. Dr ${ }^{\mathrm{a}}$. Luciana Raccanello Storto, por me introduzir na pesquisa acadêmica, contribuir e prestar auxílio de várias maneiras ao longo de todo o trabalho. Ao Prof. Dr. Didier Demolin, que dispôs de seu tempo, conhecimento e experiência para me auxiliar no trabalho de análise fonética e me orientar nos rumos da pesquisa.

A todos os professores do Departamento de Linguística da FFLCH/USP que participaram de alguma maneira da minha formação linguística nas aulas e nos eventos acadêmicos. Aos funcionários do Departamento de Linguística, pela orientação nas questões burocráticas.

Ao povo Dâw, que me acolheu amigavelmente e me permitiu estudar a sua língua, e, especialmente, a todos os falantes da língua Dâw que tomaram parte solícita e atenciosamente nas sessões de gravação.

Aos meus pais, Anselmo e Rosana, à minha irmã, Dafne, e à minha avó, Anna, pelo apoio, pelo carinho e por minha formação como pessoa. À minha companheira amada Lívia, que sempre me ofereceu ajuda, amparo e me deu estímulo para concluir o trabalho.

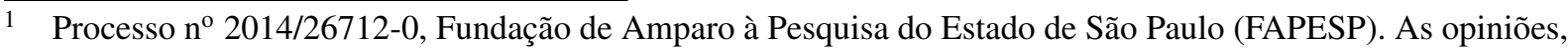
hipóteses e conclusões ou recomendações expressas neste material são de responsabilidade do autor e não necessariamente refletem a visão da FAPESP.

2 Processo $\mathrm{n}^{\mathrm{0}}$ 130159/2015-8. O presente trabalho foi realizado com apoio do CNPq, Conselho Nacional de Desenvolvimento Científico e Tecnológico - Brasil. 

Todos nós, brasileiros, somos carne da carne daqueles pretos e índios supliciados. Todos nós brasileiros somos, por igual, a mão possessa que os supliciou.

\section{(...)}

A mais terrivel de nossas heranças é esta de levar sempre conosco a cicatriz de torturador impressa na alma e pronta a explodir na brutalidade racista e classista. Ela é que incandesce, ainda hoje, em tanta autoridade brasileira predisposta a torturar, seviciar e machucar os pobres que lhes caem às mãos. Ela, porém, provocando crescente indignação nos dará forças, amanhã, para conter os possessos e criar aqui uma sociedade solidária.

(RIBEIRO, Darcy. O Povo Brasileiro: A formação e o sentido do Brasil. 2a ed. São Paulo: Companhia das Letras, 1995, p. 120.) 



\section{Resumo}

BARBOZA, L. C. Aspectos da glotalização na língua Dâw: um estudo de fonética experimental. Dissertação (Mestrado) - Universidade de São Paulo, São Paulo, 2017.

Esta dissertação analisa alguns aspectos fonéticos e fonológicos das consoantes glotalizadas da língua Dâw. Argumenta-se a favor da proposta de que, na língua Dâw, a glotalização é uma propriedade segmental e distintiva, conforme descrito por Martins (2004), restrita à classe das consoantes soantes. Observa-se mais de uma forma fonética nas consoantes glotalizadas, que incluem, sobretudo, fonação rangeada e voz áspera (ESLING; HARRIS, 2003). Quando comparadas às consoantes simples equivalentes, as consoantes glotalizadas são, em geral, mais curtas, têm forma de onda dos ciclos glotais mais irregular, H1-H2 menor e frequência fundamental mais alta (nos casos sem rangeado). Exceto pelos níveis de frequência fundamental, as propriedades acústicas dos segmentos vizinhos não são afetadas. A glotalização confina-se ou manifesta-se com maior intensidade nas partes das consoantes que se encontram mais distantes das vogais adjacentes, padrão que também foi notado em outras línguas do mundo (PLAUCHÉ et al., 1998). Verificou-se que o aumento de frequência fundamental causado pela glotalização não provoca restrições no sistema tonal da língua Dâw e que os níveis de frequência fundamental dos tons lexicais são priorizados. A confirmação fonética do processo de redução silábica descrito por Martins (2004) permite defender que a glotalização e a oclusiva glotal compartilham o mesmo traço ou se definem por gestos semelhantes, sobretudo porque a comparação das características de ambas e a avaliação das consoantes soantes vizinhas de oclusivas glotais reforçam a semelhança. Entretanto, não há dados suficientes para sustentar a proposta de Martins (2005) de que as consoantes glotalizadas da língua Dâw originaram-se simplesmente da incorporação de traços das oclusivas glotais pelas consoantes simples. Por fim, observou-se que as ocorrências das formas da glotalização se relacionam com a nasalidade dos segmentos e com o sexo e a faixa etária dos falantes. A relação entre nasalidade e forma da glotalização, assim como o padrão temporal das consoantes glotalizadas, talvez possam ser explicados por fatores aerodinâmicos ou perceptuais (GORDON; LADEFOGED, 2001). Entretanto, este estudo não pôde avançar na compreensão da motivação desses fatos. A relação entre sexo, faixa etária e forma da glotalização não indica mudança em curso e demanda uma pesquisa sociolinguística mais aprofundada.

Palavras-chave: línguas indígenas, Nadahup, Dâw, tipos de fonação, glotalização, fonação rangeada, voz áspera. 



\section{Abstract}

BARBOZA, L. C. Aspects of glottalization in Dâw: an experimental phonetics study. Thesis (MA) - Universidade de São Paulo, São Paulo, 2017.

This thesis analyses some phonetic and phonological aspects of the glottalized sonorants of Dâw language. It argues in favor of the proposal that characterizes glottalization in Dâw language as a contrastive and a segmental property restricted to the class of the sonorant consonants (MARTINS, 2004). It describes more than one phonetic form for the glottalized consonants, mainly including creaky voice and harsh voice (ESLING; HARRIS, 2003). In general, the glottalized consonants are shorter, their glottal cycles have a more irregular waveform, they have smaller $\mathrm{H} 1-\mathrm{H} 2$ and higher fundamental frequency (when creaky voice is absent) than the correspondent plain consonants. Except for the fundamental frequency levels, glottalization does not affect the acoustic properties of the neighbor segments. Glottalization is limited to or appears more noticeably in the parts of the consonants that are found at a greater distance from the neighbor vowels, a pattern that was also found in other languages (PLAUCHÉ et al., 1998). It was found that the increase in the fundamental frequency caused by glottalization does not restrict the tonal system in Dâw and the fundamental frequency levels of the lexical tones are prioritized. The phonetic confirmation of the process of syllable reduction described by Martins (2004) allows us to defend that glottalization and the glottal stop share the same feature or are defined by similar gestures, especially because the similarity is reinforced by the phonetic comparison between both phonemic entities and by the evaluation of the sonorant consonants in the neighborhood of the glottal stops. However, there is not sufficient information to sustain the proposal of Martins (2005) that the glottalized consonants in Dâw were originated merely from the incorporation of the glottal stop features by the plain consonants. Finally, this thesis notes that the occurrences of the glottalization types relate with the nasalization of the segments and the sex and the age group of the speakers. The relation between nasalization and glottalization type, as well as the glottalization timing, perhaps can be explained by aerodynamic and perceptual factors (GORDON; LADEFOGED, 2001). Nevertheless, this study was not able to deepen the understanding of the reasons for the aforementioned facts. The relation between sex, age group and glottalization type does not imply an ongoing change and demands further sociolinguistic research.

Keywords: indigenous languages, Nadahup, Dâw, phonation types, glottalization, creaky voice, harsh voice. 



\section{Lista de ilustrações}

Figura 1 - Três tipos de tensão aplicáveis às pregas vocais segundo Laver (1980) . . 40

Figura 2 - Tipos de fonação simples e compostos de acordo com Laver (1994) . . . . . 41

Figura 3 - Demarcação dos tipos de fonação em uma escala contínua de fechamento da glote de acordo com Gordon e Ladefoged (2001) . . . . . . . . . . . 43

Figura 4 - Oscilograma (A), espectrograma (B) e curva de frequência fundamental (C) da palavra $/ \mathrm{m} \hat{\tilde{\partial}} /$ pronunciada por $\mathrm{DL} \ldots \ldots . \ldots . \ldots 48$

Figura 5 - Oscilograma (A), espectrograma (B) e curva de frequência fundamental (C) da palavra $/ \mathrm{m}^{2} \hat{\tilde{\partial}} /$ pronunciada por $\mathrm{DL} \ldots \ldots \ldots \ldots$

Figura 6 - Oscilograma (A), espectrograma (B) e curva de frequência fundamental (C) da palavra /laj/ pronunciada por OC . . . . . . . . . . . . . 48

Figura 7 - Oscilograma (A), espectrograma (B) e curva de frequência fundamental (C) da palavra /lăj’/pronunciada por OC . . . . . . . . . . . . . 48

Figura 8 - Oscilograma (A) e curva de frequência fundamental (B) da palavra $/ w^{2} \check{\gamma}_{j}^{2} /$ pronunciada por $\mathrm{SL} \ldots \ldots \ldots$. . . . . . . . . . . 50

Figura 9 - Oscilograma (A), espectrograma (B) e curva de frequência fundamental (C) da palavra $/ \mathrm{j}^{2} \mathrm{rn} /$ pronunciada por PD . . . . . . . . . . . 50

Figura 10 - Oscilograma (A), espectrograma (B) e curva de frequência fundamental (C) da palavra $/$ Raw $/$ pronunciada por JR . . . . . . . . . . . . . 50

Figura 11 - Oscilograma (A), espectrograma (B) e curva de frequência fundamental (C) da palavra $/$ bã ${ }^{2} /$ pronunciada por $\mathrm{SL} \ldots \ldots$. . . . . . . . . . . 51

Figura 12 - Oscilograma (A) e curva de frequência fundamental (B) da palavra /lax/ pronunciada por DL . . . . . . . . . . . . . . 55

Figura 13 - Oscilograma (A) e curva de frequência fundamental (B) da palavra $/ 1^{2} \mathrm{ax} /$ pronunciada por DL . . . . . . . . . . . . . 55

Figura 14 - Espectro FFT da consoante /1/ da palavra /lax/, representada na figura 12 . . 56

Figura 15 - Espectro FFT da consoante $/ 1^{2} /$ da palavra $/ l^{2} \mathrm{ax} /$, representada na figura 13 . 56

Figura 16 - Oscilograma (A) e curva de frequência fundamental (B) da palavra /mỗ// pronunciada por JR . . . . . . . . . . . . . . 56

Figura 17 - Oscilograma (A) e curva de frequência fundamental (B) da palavra $/ \mathrm{m}^{2} \hat{\tilde{\partial}} /$ pronunciada por JR . . . . . . . . . . . . . . 56

Figura 18 - Oscilograma (A) e curva de frequência fundamental (B) da palavra $/ \mathrm{m}^{2} \hat{\tilde{\partial}} /$

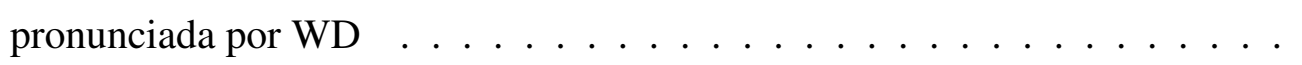

Figura 19 - Oscilograma (A) e curva de frequência fundamental (B) da palavra /wrj?/ pronunciada por $\mathrm{SL} \ldots \ldots \ldots \ldots$. . . . . . . . . . . 58

Figura 20 - Oscilograma (A) e curva de frequência fundamental (B) da palavra $/ w^{2} \check{\gamma}_{j}{ }^{2} /$ pronunciada por $\mathrm{SL} \ldots \ldots \ldots \ldots$. . . . . . . . . . . . . . . . 
Figura 21 - Comparação das médias de duração (em milissegundos) de consoantes simples e glotalizadas de grupos pareados, com marcação dos desvios-padrão .

Figura 22 - Comparação das médias de frequência fundamental (em Hz) de consoantes simples e glotalizadas de grupos pareados, com marcação dos desvios-padrão 63

Figura 23 - Comparação das médias de periodicidade (autocorrelação) de consoantes simples e glotalizadas de grupos pareados, com marcação dos desvios-padrão 64

Figura 24 - Comparação das médias de H1-H2 (em dB) de consoantes simples e glotalizadas de grupos pareados, com marcação dos desvios-padrão . . . . . . . .

Figura 25 - Oscilograma (A) e curva de frequência fundamental (B) da palavra $/ \mathrm{w}^{2} \check{\gamma}^{\mathrm{j}} \mathrm{l}$ pronunciada por VT . . . . . . . . . . . . . . . . .

Figura 26 - Demarcação das partes de $\left[1^{2}\right]$ e [a] em um oscilograma da palavra $/ 1^{2} \mathrm{ax} /$ pronunciada por DO . . . . . . . . . . . . .

Figura 27 - Demarcação das partes de [o] e [n²] em um oscilograma da palavra /lon? pronunciada por MT . . . . . . . . . . . . . . .

Figura 28 - Médias de frequência fundamental de três partes de mesma duração de consoantes simples, de consoantes glotalizadas com rangeado e das vogais adjacentes às consoantes de ambos os tipos . . . . . . . . . . . . .

Figura 29 - Médias de frequência fundamental de três partes de mesma duração de consoantes simples, de consoantes glotalizadas sem rangeado e das vogais adjacentes às consoantes de ambos os tipos . . . . . . . . . . . . . .

Figura 30 - Médias de periodicidade de três partes de mesma duração de consoantes simples, de consoantes glotalizadas com rangeado e das vogais adjacentes às consoantes de ambos os tipos . . . . . . . . . . . . . . . . . . .

Figura 31 - Médias de periodicidade de três partes de mesma duração de consoantes simples, de consoantes glotalizadas sem rangeado e das vogais adjacentes às consoantes de ambos os tipos . . . . . . . . . . . . . . .

Figura 32 - Médias de H1-H2 de três partes de mesma duração de consoantes simples, de consoantes glotalizadas com rangeado e das vogais adjacentes às consoantes de ambos os tipos . . . . . . . . . . . . . . . .

Figura 33 - Médias de H1-H2 três partes de mesma duração de consoantes simples, de consoantes glotalizadas sem rangeado e das vogais adjacentes às consoantes de ambos os tipos . . . . . . . . . . . . . . . .

Figura 34 - Oscilograma (acima) e curva de frequência fundamental (abaixo) da palavra /wâm/ . . . . . . . . . . . . . . . . . .

Figura 35 - Oscilograma (acima) e curva de frequência fundamental (abaixo) da palavra

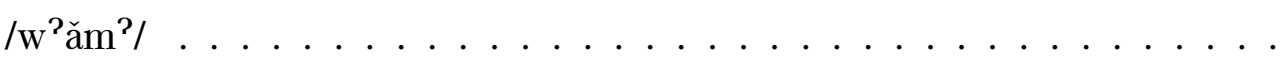

Figura 36 - Oscilograma (acima) e curva de frequência fundamental (abaixo) da frase $/ \mathrm{ngg} \mathrm{brh} / \ldots \ldots \ldots \ldots \ldots \ldots \ldots$ 
Figura 37 - Oscilograma (acima) e curva de frequência fundamental (abaixo) da frase

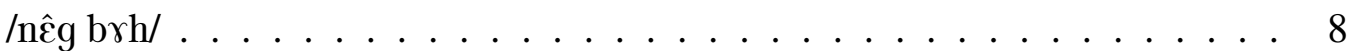

Figura 38 - Oscilograma (acima) e curva de frequência fundamental (abaixo) da palavra $/ \mathrm{m} \tilde{\tilde{\partial}} / \ldots \ldots \ldots \ldots \ldots$

Figura 39 - Oscilograma (acima) e curva de frequência fundamental (abaixo) da frase $/ \mathrm{Ra}-\mathrm{w}^{2} \mathrm{\gamma j}^{2} \mathrm{~m}^{2} \tilde{\varepsilon} \mathrm{r} \mathrm{m} \tilde{\tilde{J}} /$

Figura 40 - Oscilograma (acima) e curva de frequência fundamental (abaixo) da palavra /lǎj?

Figura 41 - Oscilograma (acima) e curva de frequência fundamental (abaixo) da frase $/$ १ãh lăj . . . . . . . . . . . . . . . . . . . . . . . . . .

Figura 42 - Oscilograma com curva de intensidade acústica sobreposta (acima) e curva de frequência fundamental (abaixo) da palavra /o.'jªh/ . . . . . . . . . .

Figura 43 - Oscilograma com curva de intensidade acústica sobreposta (acima) e curva de frequência fundamental (abaixo) da frase /tih $\mathrm{e} \tilde{\mathrm{a}} / \ldots$. . . . . . . . . . . . 85

Figura 44 - Oscilograma com curva de intensidade acústica sobreposta (acima) e curva de frequência fundamental (abaixo) da palavra /nũh brd/

Figura 45 - Oscilograma com curva de intensidade acústica sobreposta (acima) e curva de frequência fundamental (abaixo) da palavra /wǒh bôrd tih nũh/ . . . . . .

Figura 46 - Oscilograma (acima) e curva de frequência fundamental (abaixo) da palavra $/ \mathrm{w}^{2} \mathrm{en} /$ pronunciada por VT . . . . . . . . . . . . . . .

Figura 47 - Oscilograma (acima) e curva de frequência fundamental (abaixo) da palavra $/ \mathrm{w}^{2} \hat{\gamma} /$ pronunciada por ES

Figura 48 - Oscilograma (acima) e curva de frequência fundamental (abaixo) da palavra $/ \mathrm{w}^{2} \check{\gamma}_{\mathrm{j}} \mathrm{P} /$ pronunciada por SL

Figura 49 - Oscilograma (acima) e curva de frequência fundamental (abaixo) da palavra $/ \mathrm{w}^{2} \hat{\mathrm{j}}^{\mathrm{j}} /$ pronunciada por MT .

Figura 50 - Oscilograma (acima) e curva de frequência fundamental (abaixo) da palavra $/ \mathrm{dej}^{2} /$ pronunciada por WD . . . . . . . . . . . . . . . . .

Figura 51 - Oscilograma (acima) e curva de frequência fundamental (abaixo) da palavra $/ \mathrm{w}^{2} \check{\gamma}_{\mathrm{j}}^{\mathrm{T}} /$ pronunciada por MT

Figura 52 - Oscilograma (acima) e espectrograma (abaixo) da palavra /tih/ pronunciada por ES . . . . . . . . . . . . . . . . . . .

Figura 53 - Oscilograma (acima) e espectrograma (abaixo) da palavra /tihễ $f /$ pronunciada por ES

Figura 54 - Oscilograma (acima) e espectrograma (abaixo) da palavra /Rãm/ pronunciada por ES

Figura 55 - Oscilograma (acima) e espectrograma (abaixo) da palavra $/ \mathrm{m}^{2} \hat{\tilde{\varepsilon}}^{\mathrm{J}} /$ pronunciada por ES 
Figura 56 - Oscilograma (acima) e espectrograma (abaixo) da palavra /tihǘj ${ }^{2} /$ pronunciada por ES . . . . . . . . . . . . . . . . . 91

Figura 57 - Oscilograma (acima) e espectrograma (abaixo) da palavra $/ \mathrm{m}^{2} \tilde{\tilde{u}} j^{2} /$ pronunciada por ES . . . . . . . . . . . . . . . . . . . . . 99

Figura 58 - Oscilograma (A), espectrograma (B) e curva de frequência fundamental (C) da palavra /Rãm/ pronunciada por PD . . . . . . . . . . . . . . . . 92

Figura 59 - Oscilograma (A), espectrograma (B) e curva de frequência fundamental (C) da palavra /Rãm/ pronunciada por NZ . . . . . . . . . . . . . . . . . . 92

Figura 60 - Oscilograma (A), espectrograma (B) e curva de frequência fundamental (C) da palavra $/$ ãm/ pronunciada por MT . . . . . . . . . . . . . . 93

Figura 61 - Oscilograma (acima) e espectrograma (abaixo) da frase $/ \mathrm{m}^{2} \tilde{\varepsilon} \mathrm{\imath}$ mõ $/$ pronunciada por VT . . . . . . . . . . . . . . . . . . . . . 93

Figura 62 - Oscilograma (acima) e espectrograma (abaixo) da palavra /mỗ/ pronunciada por DL . . . . . . . . . . . . . . . . . . . . . . . 94

Figura 63 - Oscilograma (acima) e espectrograma (abaixo) da palavra $/ \mathrm{m}^{2} \hat{\tilde{\tilde{o}}} /$ pronunciada por DL . . . . . . . . . . . . . . . . . . . . . . . . . . . . . 94

Figura 64 - Oscilograma (acima) e espectrograma (abaixo) da frase $/ \mathrm{m}^{2} \tilde{\varepsilon} \mathrm{P} \mathrm{m}^{2} \hat{\tilde{\partial}} /$ pronunciada por WD . . . . . . . . . . . . . . . . . . . . 94 


\section{Lista de tabelas}

Tabela 1 - Inventário dos segmentos consonantais da língua Dâw de acordo com Martins (2004) . . . . . . . . . . . . . . . . . 2 29

Tabela 2 - Inventário dos segmentos vocálicos da língua Dâw de acordo com Martins (2004) . . . . . . . . . . . . . . . . . . . . 29

Tabela 3 - Lista de palavras e frases preparada para o trabalho de campo de 2015 . . 34

Tabela 4 - Informações sobre os participantes da coleta de dados de 2015 . . . . . . . 37

Tabela 5 - Pares mínimos e análogos coligidos por Martins (2004) . . . . . . . . . . 49

Tabela 6 - Informações sobre as palavras presentes no corpus do estudo quantitativo sobre as propriedades acústicas da glotalização . . . . . . . . . . . . . . 59

Tabela 7 - Diferenças estatísticas, resultados de testes t e tamanhos de efeito $d$ de Cohen para quatro propriedades acústicas de consoantes simples e glotalizadas de

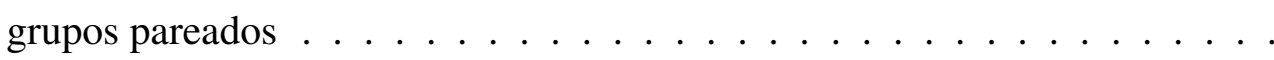

Tabela 8 - Diferenças estatísticas, resultados de testes t e tamanhos de efeito $d d e$ Cohen para três propriedades acústicas de três partes de mesma duração de consoantes simples e glotalizadas de grupos pareados . . . . . . . . . . 75

Tabela 9 - Diferenças estatísticas, resultados de testes t e tamanhos de efeito $d$ de Cohen para três propriedades acústicas de três partes de mesma duração de vogais adjacentes a consoantes simples e glotalizadas de grupos pareados . . . . . 78

Tabela 10 - Pares mínimos e análogos de palavras atonais e tonais com os tons descendente e ascendente, segundo Martins $(2004,84-85)$. . . . . . . . . . .

Tabela 11 - Distribuição das consoantes glotalizadas nas categorias de nasalidade e forma da glotalização . . . . . . . . . . . . . . . . . . . . . . . . 9 98

Tabela 12 - Distribuição das formas da glotalização nas gravações dos participantes da coleta de dados de 2015 . . . . . . . . . . . . . . . . . . . . .

Tabela 13 - Distribuição das consoantes glotalizadas nas categorias de faixa etária e forma da glotalização . . . . . . . . . . . . . . . . . . 100

Tabela 14 - Distribuição das consoantes glotalizadas nas categorias de sexo e forma da glotalização . . . . . . . . . . . . . . . . . . 100 



\title{
Lista de abreviaturas e siglas
}

\author{
1SG primeira pessoa do singular \\ 2SG segunda pessoa do singular \\ AFET caso afetado \\ FFT Fast Fourrier Transform \\ FOC foco \\ GEN caso genitivo \\ H1-H2 diferença entre a amplitude do primeiro e do segundo harmônico de um \\ espectro \\ PB Português brasileiro
}





\section{Lista de símbolos}

$\mathrm{C}$

qualquer consoante relevante no contexto (admite índices subscritos para evitar ambiguidade)

S

qualquer consoante da classe das soantes relevante no contexto (admite índices subscritos para evitar ambiguidade)

$\mathrm{S}^{2} \quad$ qualquer consoante glotalizada da classe das soantes relevante no contexto (admite índices subscritos para evitar ambiguidade)

qualquer vogal relevante no contexto (admite índices subscritos para evitar ambiguidade)

$\mathrm{O}$

qualquer consoante da classe das oclusivas relevante no contexto (admite índices subscritos para evitar ambiguidade)

fronteira de sílaba

indica que a forma não é permitida ou atestada na língua

Todos os símbolos empregados nas transcrições fonéticas e fonológicas deste trabalho encontram-se no Alfabeto Fonético Internacional, exceto o símbolo de oclusiva glotal sobrescrita, que é aqui adotado para designar a glotalização (ver seção 2.2). 



\section{Sumário}

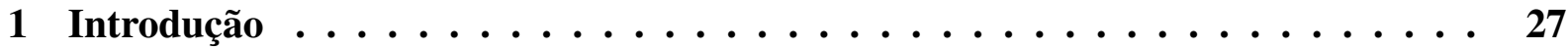

1.1 A língua Dâw, os seus falantes e a sua família linguística . . . . . . . . . . . 28

1.1.1 A língua Dâw na literatura acadêmica . . . . . . . . . . . . . . . . 29

1.1.2 A família linguística Nadahup . . . . . . . . . . . . . . . . 31

1.2 Descrição dos trabalhos de campo . . . . . . . . . . . . . . . . . . 33

1.2 .1 Materiais . . . . . . . . . . . . . . . . . 33

1.2 .2 Equipamentos . . . . . . . . . . . . . . . . . 37

1.2 .3 Participantes . . . . . . . . . . . . . . . . . 37

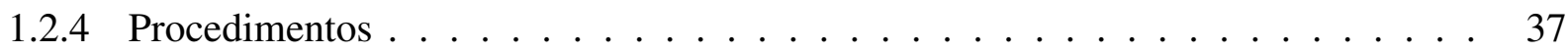

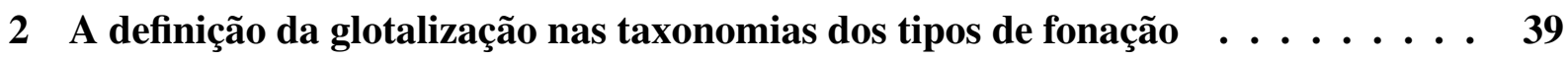

2.1 Três sistemas de classificação dos tipos de fonação . . . . . . . . . . . . . . . . 39

2.2 Os significados dos termos "glotalização" e "laringalização" . . . . . . . . . . . . . 45

3 O papel da glotalização no sistema fonológico . . . . . . . . . . . . . . . . 47

4 Algumas propriedades fonéticas da glotalização $\ldots \ldots \ldots \ldots \ldots$

4.1 Descrição do corpus . . . . . . . . . . . . . . . . . . . . 58

4.2 Metodologia . . . . . . . . . . . . . . . . . . . . . 59

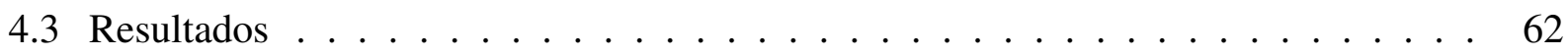

4.4 Discussão . . . . . . . . . . . . . . . . . . . . . . . 66

5 As propriedades acústicas da glotalização no domínio do tempo . . . . . . . . . 69

5.1 Metodologia . . . . . . . . . . . . . . . . . . 70

5.2 Resultados . . . . . . . . . . . . . . . . . . . . 72

5.3 Discussão . . . . . . . . . . . . . . . . . . . . . . . . 77

6 Interações entre a glotalização e o sistema tonal . . . . . . . . . . . . . . . 81

6.1 O sistema tonal e acentual da língua Dâw . . . . . . . . . . . . . . . 81

6.2 A coexistência de tom e glotalização . . . . . . . . . . . . . . . . 86

7 O processo de redução silábica e o surgimento das consoantes glotalizadas . . . . 89

7.1 O processo de redução silábica . . . . . . . . . . . . . . . . . 89

7.2 A oclusiva glotal, as consoantes soantes e a glotalização . . . . . . . . . . . . 92

7.3 O surgimento da glotalização . . . . . . . . . . . . . . . . . . . . . . . . . . . . . . . . . . . . .

8 A distribuição das formas da glotalização . . . . . . . . . . . . . . . . 97

8.1 As formas fonéticas da glotalização e a nasalidade . . . . . . . . . . . . . . . . 97

8.2 As formas fonéticas da glotalização e fatores não-linguísticos . . . . . . . . . . . . 99

Considerações finais . . . . . . . . . . . . . . . . 101

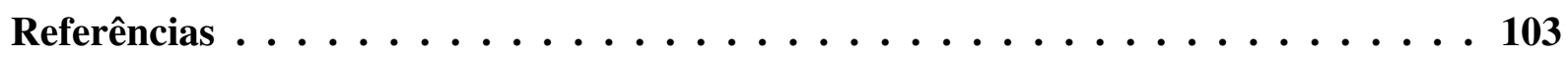


Apêndices

APÊNDICE A Apresentação da pesquisa à comunidade Dâw . . . . . . . . . . 109 


\section{1}

\section{Introdução}

Este trabalho examina alguns aspectos fonológicos e, principalmente, fonéticos das consoantes glotalizadas da língua Dâw. Pretende-se, em primeiro lugar, oferecer uma análise detalhada das características fonéticas desses segmentos, a fim de subsidiar a tarefa de identificação e distinção das consoantes glotalizadas ${ }^{1}$ - necessária a qualquer estudo de natureza fonológica de contribuir com o quadro de pesquisa das articulações laríngeas e dos tipo de fonação e de dirimir confusões na descrição, na situação tipológica e genética da glotalização. A pesquisa também lida com questões mais complexas que estão atreladas ao sistema fonológico ou às propriedades fonéticas dos segmentos da língua Dâw, mas que também são relevantes para outras línguas e para o estudo geral das articulações laríngeas e dos tipos de fonação, como o padrão temporal da glotalização e a relação entre a glotalização e as oclusivas glotais. Além do interesse linguístico, salienta-se a importância dos estudos sobre as línguas indígenas para a sua valorização e, espera-se, para a sua preservação.

As seções seguintes deste capítulo apresentam informações a respeito dos falantes e da região em que a língua Dâw é falada (seção 1.1), mencionam e resumem trabalhos acadêmicos que descrevem e analisam a língua (subseção 1.1.1), tratam, de maneira sumária, da família linguística da língua Dâw (Nadahup), da descrição da glotalização nas línguas aparentadas (subseção 1.1.2) e relatam os trabalhos de campo destinados à formação do corpus desta pesquisa. O capítulo 2 resume e discute três propostas de classificação das articulações laríngeas e dos tipos de fonação (seção 2.1), trata dos significados dos termos "laringalização" e "glotalização" e define explicitamente a acepção de "glotalização" adotada nesta pesquisa (seção 2.2). O capítulo 3 aborda o papel fonológico da glotalização; mais especificamente, o seu caráter distintivo, a sua distribuição entre as classes de fonemas e a sua natureza fonológica como traço ou gesto. No capítulo 4, analisam-se quantitativamente algumas propriedades acústicas das consoantes glotalizadas através de quatro medidas acústicas já exploradas na literatura: duração, $\mathrm{H} 1-\mathrm{H} 2^{2}$, níveis de frequência fundamental e periodicidade. No capítulo seguinte (capítulo 5), realizam-se as mesmas medições feitas no estudo do capítulo 4, mas, desta vez, as consoantes glotalizadas

1 Em alguns casos, sobretudo quando não há rangeamento (ver capítulo 4), a glotalização não é prontamente percebida com a audição e até mesmo com o exame de oscilogramas e espectrogramas; um estudo fonético mais detalhado faz-se necessário.

2 Medida espectral que consiste na subtração da amplitude do primeiro harmônico pela amplitude do segmento harmônico. Ver capítulo 4. 
e as vogais adjacentes são divididas em partes sucessivas e de mesma duração, com o objetivo de verificar se a glotalização se confina a regiões específicas dos segmentos e de compreender como ela afeta os segmentos vizinhos. O capítulo 6 avalia a interação entre a glotalização e o sistema tonal, uma vez que ambos provocam alterações nos níveis de frequência fundamental. $\mathrm{O}$ capítulo 7 aborda o surgimento de consoantes glotalizadas no processo de redução silábica de alguns pronomes da língua Dâw e compara as características fonéticas das oclusivas glotais e da glotalização. O último capítulo (capítulo 8) estuda a influência de um fator linguístico - a nasalidade - e de dois fatores não-linguísticos - sexo e faixa etária - na distribuição das formas da glotalização.

\subsection{A língua Dâw, os seus falantes e a sua família linguística}

A língua Dâw é uma língua brasileira falada por 134 pessoas, segundo censo realizado pelo povo Dâw em 2014 (ANDRADE, 2014, p. 1). O número exíguo de pessoas da etnia e de falantes da língua Dâw deve-se, mais recentemente, ao período em que trabalharam na extração da piaçava. Os homens brancos envolvidos no comércio do produto exploravam intensamente a mão de obra e cometiam atos brutais de violência contra os Dâw (MARTINS, 2004, p. 4). Os Dâw caracterizavam-se, tradicionalmente, como um povo nômade que habitava o interior das florestas e garantia a subsistência com a prática da caça e da coleta (MARTINS, 2004, p. 2-4). Atualmente, o povo Dâw reside em uma comunidade denominada Waruá, próximo ao município de São Gabriel da Cachoeira (Amazonas), na região do Médio Rio Negro. Nos últimos anos, as condições de vida melhoraram significativamente e a mortalidade reduziu, resultando no aumento do número de pessoas da etnia Dâw, que mantêm a sua cultura e a sua língua vivas.

O etnônimo "Dâw" é o termo que o povo Dâw utiliza para se referir a si próprio e à sua língua. Trata-se de uma palavra bastante comum na língua Dâw e significa, literalmente, "pessoa" e "povo" (ASSIS, 2007; MARTINS, 2004). Os falantes da língua Dâw geralmente dominam também outras línguas, em especial, o português brasileiro e, entre os falantes mais idosos, o Nheengatu, que é um veículo de comunicação intertribal. Aikhenvald (2012) situa a língua Dâw na periferia de uma área linguística demarcada pela bacia do rio Vaupés. Nesta região, notável pela imensa diversidade linguística, encontram-se três famílias linguísticas: Aruak, Tukano Oriental e Nadahup (AIKHENVALD, 2012, p. 75), que é a família linguística da língua Dâw (ver subseção 1.1.2). As línguas da família Nadahup não participam da exogamia linguística encontrada nas tribos Aruak e Tukano (STENZEL, 2005, p. 1). Há algumas características fonéticas e fonológicas semelhantes entre as línguas Tukano e Nadahup, como tom, nasalidade e glotalização. As línguas Tukano Oriental faladas na região do Vaupés do Brasil e da Colômbia ${ }^{3}$ também apresentam uma forma de glotalização ${ }^{4}$. Stenzel (2007) defende que a glotalização é uma propriedade suprassegmental dos morfemas de raiz, algo distinto do que ocorre na língua Dâw, em que a glotalização se define no nível segmental (ver capítulo 3).

3 Wanano, Piratapuyo, Tukano, Desano e Siriano (STENZEL, 2007, p. 332).

4 Orjuela (2014) analisa a glotalização em três línguas Tukano de um ponto de vista fonético. 


\subsubsection{A língua Dâw na literatura acadêmica}

O trabalho mais extenso e abrangente sobre a língua Dâw foi escrito por Martins (2004). Em sua tese de doutorado, Martins (2004) abordou vários aspectos da língua Dâw, da fonologia à sintaxe. A autora estabeleceu um inventário fonológico constituído de vinte e cinco consoantes ${ }^{5}$ e quinze vogais, que constam nas tabelas 1 e 2, na ordem respectiva. Martins (2004) classifica as consoantes da língua Dâw em dois grupos: não-soantes e soantes (MARTINS, 2004, p. 16). As não-soantes equivalem às consoantes da classe das obstruintes, ou seja, são oclusivas e fricativas. Por sua vez, as soantes compreendem, na língua Dâw, consoantes nasais, aproximantes e aproximantes laterais. A divisão das consoantes fundamenta-se, dentre outras coisas, na existência da glotalização como propriedade distintiva (MARTINS, 2004, p. 16). No nível suprassegmental, a língua Dâw apresenta outras características destacáveis. As palavras são, em geral, monomorfêmicas e monossilábicas, ou seja, há frequentemente isomorfismo de sílaba, morfema e palavra (MARTINS, 2004, p. 69). O padrão silábico mais comum para as formas livres é o CVC (ocorre também CV:) e para os poucos sufixos encontrados é o VC (MARTINS, 2004, p. 68-76). A autora descreve também o sistema tonal da língua, formado por dois tons distintivos - ascendente e descendente -, que produzem alongamento da vogal, e tom zero (atonal) (MARTINS, 2004, p. 78).

\begin{tabular}{|c|c|c|c|c|c|c|}
\hline & Bilabial & Alveolar & Pós-alveolar & Palatal & Velar & Glotal \\
\hline Oclusivas & $\mathrm{p}$ & $\mathrm{t}$ & & $\mathrm{c}$ & $\mathrm{k}$ & $?$ \\
\hline & b & $\mathrm{d}$ & & $\mathrm{f}$ & $\mathrm{g}$ & \\
\hline Fricativas & & & $\int$ & & $\mathrm{x}$ & $\mathrm{h}$ \\
\hline Nasais & $\begin{array}{c}\mathrm{m} \\
\mathrm{m}^{?}\end{array}$ & $\begin{array}{c}\mathrm{n} \\
\mathrm{n}^{2}\end{array}$ & & $\begin{array}{c}\mathrm{n} \\
\mathrm{n}^{2}\end{array}$ & $\mathrm{y}$ & \\
\hline Aproximantes laterais & & $\begin{array}{c}1 \\
1^{?}\end{array}$ & & & & \\
\hline Aproximantes & & & & $\begin{array}{l}j \\
j^{?}\end{array}$ & $\begin{array}{c}\mathrm{w} \\
\mathrm{w}^{?}\end{array}$ & \\
\hline
\end{tabular}

Tabela 2 - Inventário dos segmentos vocálicos da língua Dâw de acordo com Martins (2004)

$\mathrm{i} \tilde{\mathrm{i}}$ uथ $\tilde{u} u \tilde{u}$

$\mathrm{e}$ ro $\varepsilon \tilde{\varepsilon} \quad$ o $\tilde{\jmath}$ a ã

5 No capítulo 3, demonstra-se a existência de uma consoante não relatada por Martins (2004): a consoante nasal, velar e glotalizada, representada pelo símbolo $/ \mathrm{y}^{\%} \%$ 
Martins (2004) divide as consoantes soantes da língua Dâw em duas séries, uma de consoantes simples e a outra de consoantes glotalizadas (MARTINS, 2004, p. 16). De acordo com a tabela 1, há consoantes equivalentes nas duas séries, exceto pela nasal velar, que se apresenta apenas como consoante simples $(\mathrm{y})^{6}$. Para corroborar a tese de que a glotalização possui valor fonológico, Martins (2004) fornece doze pares mínimos e análogos ${ }^{7}$, um para cada consoante soante em cada posição silábica possível: ataque e coda silábica (MARTINS, 2004, p. 20-22). A lista de palavras, mostrada na tabela 5, é convincente e foi corroborada com a análise fonética desenvolvida em um trabalho do autor da presente pesquisa ${ }^{8}$. Martins (2004) afirma que não há obstruintes glotalizadas, contudo, relata que, em posição de ataque silábico, as oclusivas /c/ e /k/ são ejetivas ${ }^{9}$, ou seja, produzidas com mecanismo de ar glotálico e egressivo (LADEFOGED; MADDIESON, 1996, p.78-81).

Martins (2004, p. 16) considera a glotalização como uma articulação adicional: "As consoantes sonorantes podem ser glotalizadas, isto é, podem ter uma articulação glotálica adicional". A autora menciona que a glotalização de consoantes soantes é "referida como laringalização" na literatura linguística (MARTINS, 2004, p. 43) e postula que as consoantes glotalizadas são produzidas com "o acréscimo de uma oclusiva glotal" (MARTINS, 2004, p. 42), manifestada foneticamente como laringalização (MARTINS, 2004, p. 42). Encontra-se realmente o uso da palavra "glotalização", na literatura linguística, para denotar, dentre outras coisas, um tipo de fonação não-modal: a fonação rangeada. Conforme a autora discute, a fonação rangeada, denominada por ela creaky voice e "laringalização", envolve maior tensão adutora nas pregas vocais, com grande aproximação das cartilagens aritenoides em estado pré-fonatório (LAVER, 1980, p. 123). Entretanto, na língua Dâw, a fonação rangeada não é geralmente precedida ou seguida por oclusão glotal completa, como Martins (2004) afirma ${ }^{10}$. O capítulo 2 debruça-se com mais detalhes sobre as questões terminológicas.

Além do trabalho de Martins (2004), existem estudos acadêmicos sobre temas mais específicos da língua Dâw. Nos últimos anos, publicaram-se três dissertações que tratam da fonologia, da morfologia e da sintaxe da língua Dâw. Andrade (2014) examina a nasalidade na língua Dâw e analisa com perspectiva fonética - por meio de dados acústicos e aerodinâmicos - e distribucional as consoantes com contorno oro-nasal que ocorrem em posição de coda silábica: $\left[{ }^{\mathrm{b}} \mathrm{m}\right],\left[{ }^{\mathrm{d}} \mathrm{n}\right],\left[{ }^{\mathrm{j}} \mathrm{n}\right]$ e $\left[{ }^{\mathrm{g}} \mathrm{n}\right]$. No trabalho de Costa (2014), estuda-se a estrutura argumental e as classes

6 Conferir a nota 5.

7 A autora denomina "pares mínimos" os pares de palavras que ela apresenta, mas é mais apropriado considerar

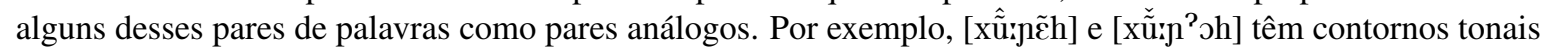
diferentes na primeira sílaba e vogais distintas na última. Note-se que tom e qualidade vocálica não são previsíveis ou alofônicos em ambas as palavras.

8 Pesquisa de Iniciação Científica (PIBIC) “Glotalização em Dâw” realizada nos anos de 2013 e 2014 sob orientação da Prof ${ }^{\mathrm{a}}$. Dr ${ }^{\mathrm{a}}$. Luciana Raccanello Storto e financiada pelo Conselho Nacional de Desenvolvimento Científico e Tecnológico (CNPq).

9 Não foram registradas oclusivas ejetivas em nenhuma das palavras gravadas desde o início da pesquisa de iniciação científica aludida na nota 8 até o final da presente pesquisa. Como foi gravado um volume considerável de palavras que deveriam conter as alegadas oclusivas ejetivas, conclui-se que não existem oclusivas ejetivas na língua Dâw, pelo menos na pronúncia atual.

10 Há alguns casos em que há realmente oclusão glotal completa, como se apontou no capítulo 4. 
verbais da língua Dâw por meio de vários testes linguísticos. Ainda no domínio da morfologia e da sintaxe, Carvalho (2016) avalia alguns morfemas interpretados por Martins (2004) como marcadores de aspecto e verifica que muitos deles desempenham outras funções.

\subsubsection{A família linguística Nadahup}

Epps (2005) defende que as línguas Dâw, Hup, Yuhup e Nadëb têm vinculação genética, sendo Nadëb a língua mais afastada do grupo (EPPS, 2005, p. 2-7). Martins (2005), por outro lado, relaciona um conjunto mais amplo de línguas, comumente denominadas Maku, em dois ramos: Oriental, que compreende Kakua, Nukak e Puinave, e Ocidental, composto por Dâw, Hup, Yuhup e Nadëb. Segundo Epps e Bolaños (Em preparação), não há evidências suficientes para defender a relação de parentesco entre, de um lado, as línguas Kakua, Nukak e Puinave e, de outro, as línguas Dâw, Hup, Yuhup e Nadëb. É importante mencionar que, em sua proposta de reconstrução, Martins (2005) trata apenas do que ele denomina Proto-Maku Oriental, de tal modo que as línguas Kakua, Nukak e Puinave não são avaliadas.

$\mathrm{Na}$ literatura acadêmica, muitos autores utilizam o termo "Maku" para referir-se à família linguística que contempla as línguas Dâw, Hup, Yuhup e Nadëb. Epps (2005) argumenta que a palavra "Maku" pode designar vários grupos étnicos e linguísticos desvinculados e trata-se provavelmente de um vocábulo Aruak com valor depreciativo (EPPS, 2005, p. 8); significaria, literalmente, "sem língua" (ASSIS, 2007, p. 32). Na falta de uma autodenominação, Epps (2005) propõe o termo "Nadahup", que reúne partes dos nomes das quatro línguas mencionadas (EPPS, 2005, p. 8). Em razão da clareza e, principalmente, da ausência de conotação pejorativa da palavra "Nadahup", o presente trabalho adota-o exclusivamente e apoia a prática sugerida por Epps (2005).

Martins (2005) propõe a reconstrução de vários aspectos fonológicos de Proto-Nadahup, denominada por ele Proto-Maku Oriental. O trabalho de Martins (2005) baseia-se em um conjunto de 591 cognatos hipotéticos, coletados pelo próprio autor, das quatro línguas Nadahup. Apesar de relativamente volumoso, muitas palavras do corpus são provavelmente empréstimos (EPPS; BOLAÑOS, Em preparação). Além disso, o estudo sofre com a falta de consistência metodológica, não leva em conta a importância das relações de contato linguístico na região em que as línguas são faladas (EPPS; BOLAÑOS, Em preparação) e não examina a possibilidade de subagrupamentos na evolução da família Nadahup. Não há outros estudos amplos voltados à reconstrução da protolíngua nem mesmo trabalhos que tratam exclusivamente de algum tema específico no desenvolvimento histórico das línguas Nadahup.

Os parágrafos seguintes desta seção apresentam um resumo das descrições da glotalização nas línguas Hup, Yuhup e Nadëb, a fim de que se possa compará-las com o que o presente trabalho descreve e examina na língua Dâw.

De acordo com Martins (2005) e Epps (2005), o inventário fonêmico da língua Hup compreende consoantes glotalizadas da classe das oclusivas e das soantes. A distinção de vozeamento, presente nas oclusivas simples, neutraliza-se nas consoantes glotalizadas. As oclusivas velar e 
palatal glotalizadas são, sob um ponto de vista fonético, desvozeadas e podem soar, em alguns casos, levemente ejetivas (EPPS, 2005, p. 56). As oclusivas bilabial e alveolar glotalizadas apresentam vozeamento segundo a descrição dos dois autores, porém somente Martins (2005) as reconhece como oclusivas implosivas. Em posição final de morfemas orais, as oclusivas glotalizadas manifestam-se como "oclusivas não-explodidas" (EPPS, 2005; MARTINS, 2005) e, por este motivo, não há distinção entre as oclusivas desvozeadas e as oclusivas glotalizadas neste contexto (EPPS, 2005, p. 56). Epps (2005) observa que a diferença entre as oclusivas desvozeadas e as oclusivas glotalizadas em posição final de morfema lexical emerge quando há sufixação (EPPS, 2005, p. 59-63). Ainda segundo a autora, os segmentos glotalizados caracterizam-se principalmente pela ocorrência de fonação rangeada no início da vogal seguinte (EPPS, 2005, p. 56). Martins (2005), por sua vez, afirma somente que a fonação rangeada pode ocorrer em vogais adjacentes a consoantes glotalizadas (MARTINS, 2005, p. 121).

As únicas consoantes da classe das soantes encontradas no inventário fonêmico da língua Hup são as aproximantes lábio-velar (w) e palatal (j), que podem ser simples ou glotalizadas (EPPS, 2005; MARTINS, 2005). As consoantes nasais, que também pertencem à classe das soantes, são alofones de oclusivas vozeadas homorgânicas. Martins (2005) defende que a língua Hup possui, dentre os seus fonemas, vogais nasais e que as oclusivas vozeadas precedentes e seguintes assimilam o seu traço de nasalidade (MARTINS, 2005, p. 121). Para Epps (2005), existem morfemas orais e nasais na língua Hup, ou seja, a nasalidade é uma propriedade suprassegmental (EPPS, 2005, p. 72-73). Nos morfemas nasais, todos os segmentos adquirem nasalização, exceto as oclusivas desvozeadas (EPPS, 2005, p. 73). Em contexto nasal, as oclusivas vozeadas e glotalizadas tornam-se consoantes nasais e glotalizadas com o mesmo ponto de articulação e não há neutralização da distinção entre oclusivas desvozeadas e oclusivas glotalizadas em posição final de morfema, ainda que seja difícil de distingui-las em alguns casos (EPPS, 2005, p. 59). Epps (2005) descreve, em termos fonéticos, as aproximantes glotalizadas em posição de final de morfema como sequências de uma aproximante simples e uma oclusiva glotal (EPPS, 2005, p. 64-65).

Lopes e Parker (1999) argumentam que a glotalização é um autossegmento flutuante associado às vogais, transcritas como [르르, na língua Yuhup. As vogais glotalizadas são longas e dividem-se em duas partes: a primeira, mais curta, apresenta fonação rangeada total e a segunda, mais longa, exibe fonação rangeada apenas em sua parte inicial (LOPES, 1995, p. 91). A segunda parte possui duração média semelhante à de uma vogal simples. Em alguns casos, ocorre interrupção do fluxo de ar entre as duas partes, como se houvesse uma oclusiva glotal entre elas (LOPES, 1995, p. 18). Para Epps (2005), não há certeza se a glotalização na língua Yuhup pode ser interpretada da mesma maneira que em Hup, ou seja, como um atributo das consoantes (EPPS, 2005, p. 69-69). Martins (2005), por sua vez, descreve como sendo basicamente idênticos a glotalização, a nasalidade e o sistema tonal em Hup e em Yuhup, salvo que em Yuhup não há restrição de tom de acordo com o vozeamento da consoante em coda silábica (MARTINS, 2005, p. 100). 
Em contraste com o que se encontra nas outras línguas Nadahup, existem vogais breves e longas no inventário fonológico da língua Nadëb. A glotalização aplica-se somente aos segmentos vocálicos, mais especificamente, às vogais longas (BARBOSA, 2005; MARTINS, 2005). Portanto, distinguem-se fonologicamente as vogais longas e glotalizadas, as vogais longas e simples e as vogais curtas (e simples). Segundo Barbosa (2005) e Martins (2005), as vogais glotalizadas da língua Nadëb caracterizam-se pela presença de fonação rangeada em sua parte final.

\subsection{Descrição dos trabalhos de campo}

Todas as gravações que formam os corpora de análise desta pesquisa foram realizadas no município de São Gabriel da Cachoeira ou no próprio local de residência dos falantes da língua Dâw pelo autor deste trabalho, por sua orientadora ou por outros pesquisadores envolvidos no trabalho de campo. Os dados obtidos durante a pesquisa de iniciação científica ${ }^{11}$ que precedeu este trabalho contribuíram, de alguma maneira, para moldar os temas e a metodologia de trabalho aqui adotadas. As gravações feitas na última etapa da pesquisa de iniciação científica, em 2014, além disso, adicionaram-se aos corpora deste trabalho. Wallace de Andrade, então aluno de mestrado sob a orientação da Prof ${ }^{\mathrm{a}}$. Dr ${ }^{\mathrm{a}}$. Luciana Raccanello Storto, e o Prof. Dr. Didier Demolin coordenaram as sessões de gravação de 2014.

Entre os dias 4 e 10 de julho de 2015, o autor deste trabalho esteve no município de São Gabriel da Cachoeira, no estado do Amazonas, sob supervisão de sua orientadora, Prof ${ }^{\mathrm{a}}$. Dr ${ }^{\mathrm{a}}$. Luciana Raccanello Storto, e em companhia de outro orientando, Maurício Carvalho. No primeiro dia de viagem, visitaram Auxiliadora Fernandes da Silva, que é capitã e representante do povo Dâw, para organizar as sessões com os participantes. Em seguida, foram à aldeia, por meio do barco que os Dâw utilizam para transporte próprio ${ }^{12}$, e lá reuniram-se, em um espaço reservado a encontros, com alguns membros da comunidade, especialmente com aqueles que pretendiam participar das pesquisas nos dias subsequentes ou em outro momento. A Prof ${ }^{\mathrm{a}}$. Dra . Luciana Raccanello Storto expôs aos presentes os planos de trabalho e assuntos relacionados. Maurício Carvalho e o autor desta pesquisa apresentaram, de maneira sucinta, os seus projetos de pesquisa, utilizando materiais previamente elaborados, que ficaram em posse dos Dâw. O apêndice A reproduz o documento referente a esta pesquisa que foi remetido à comunidade. As seções de gravação começaram no primeiro dia e se estenderam até o dia anterior à partida, 9 de julho de 2015.

\subsubsection{Materiais}

Para a realização das sessões de gravação feitas em 2014, o autor desta pesquisa reuniu o conjunto de pares mínimos e análogos apresentados por Martins (2004) (ver tabela 5). O

11 Conferir a nota 8.

12 Como a aldeia se encontra muito próximo à cidade, a ida à aldeia leva aproximadamente 10 minutos. 
material de gravação do trabalho de campo de 2015 incluía 46 palavras e frases da língua Dâw que continham segmentos específicos em contextos apropriados para as análises. Além disso, selecionaram-se também 26 palavras e frases alternativas - igualmente adequadas para os estudos que se pretendiam realizar - para substituição, caso os participantes das gravações afirmassem desconhecer as palavras ou frases inicialmente solicitadas.

Durante a produção do material de gravação de 2015, consultou-se o trabalho de Martins (2004) e a base de dados lexicais do projeto Documentation of Dâw - a Nadahup language of Brazil, coordenado pela Prof ${ }^{\mathrm{a}}$. Dr ${ }^{\mathrm{a}}$. Luciana Raccanello Storto e pela Prof $^{\mathrm{a}} \mathrm{Dr}^{\mathrm{a}}$. Patience Epps. Incluiu-se no material a tradução para o PB de todas as palavras e frases e um código de identificação baseado nos segmentos e/ou nos contextos relevantes. O código de identificação foi utilizado para produzir uma ficha para cada participante. A fim de evitar qualquer influência causada por repetição sucessiva de uma mesma palavra/frase ou de palavras/frases suscetíveis a algum tipo de associação, criou-se para, cada participante, uma ficha com os códigos de identificação dispostos aleatoriamente. Constavam nas fichas três ocorrências para cada palavra/frase da lista aludida anteriormente, exceto para os itens 1A, 1B, 2A e 2B, que contaram cada um com seis ocorrências. A lista de palavras/frases pode ser conferida na tabela 3.

Tabela 3 - Lista de palavras e frases preparada para o trabalho de campo de 2015

\begin{tabular}{|c|c|c|c|}
\hline Código & Segmento/Contexto & Transcrição & Tradução (PB) \\
\hline $1 \mathrm{~A}$ & $\mathrm{~N}$ & $\mathrm{~m} \hat{\tilde{\partial}}$ & Inambu, poça \\
\hline 1B & $\mathrm{N}^{2}$ & $\mathrm{~m}^{2 \hat{\tilde{\nu}}}$ & Irara, lontra \\
\hline $2 \mathrm{~A}$ & $\mathrm{~S}$ & wâm & Macaco cutiporó \\
\hline- & - & wôj & Abelha, rato \\
\hline 2B & $S^{?}$ & $w^{2} a ̆ m ?$ & Embaúba \\
\hline- & - & $w^{2} \hat{o j}{ }^{?}$ & Voz do guariba \\
\hline $3 \mathrm{~A}$ & $\$ S^{?}$ & $\mathrm{w}^{2} \mathrm{an}$ & Cará do mato \\
\hline $3 \mathrm{~B}$ & $\$ S^{?}$ & $\mathrm{w}^{2} \mathrm{en}$ & Sucuri \\
\hline $3 \mathrm{C}$ & $\$ S^{?}$ & $j^{2} \gamma n$ & $\begin{array}{l}\text { Balançar o corpo como la- } \\
\text { garta }\end{array}$ \\
\hline $3 \mathrm{D}$ & $\$ S^{?}$ & $w^{2} \varepsilon j$ & Mucura (gambá ou tipi) \\
\hline $3 \mathrm{E}$ & $\$ S^{2}$ & $\mathrm{n}^{2} \tilde{a} \mathrm{~m}$ & Ficar com medo de bicho \\
\hline $3 \mathrm{~F}$ & $\$ S^{?}$ & $\mathrm{j}^{\mathrm{j}} \hat{\tilde{\varepsilon}} \mathrm{W}$ & Devagar \\
\hline $4 \mathrm{~A}$ & $S^{2} \$$ & $\operatorname{lon}^{2}$ & Recolher linha de pesca \\
\hline $4 \mathrm{~B}$ & $S^{2} \$$ & lǎj? & Pescar, anzol \\
\hline $4 \mathrm{C}$ & $S^{2} \$$ & $w r j^{?}$ & Ver \\
\hline $4 \mathrm{D}$ & $S^{2} \$$ & $\mathrm{j} \varepsilon j^{?}$ & Balançar segurando no galho \\
\hline $5 \mathrm{~A}$ & $\$ S^{2} V^{2} \$$ & $w^{2} a ̆ m ?$ & Embaúba \\
\hline $5 \mathrm{~B}$ & $\$ S^{2} V^{2} \$$ & $w^{2} \hat{j} j^{?}$ & Voz do guariba \\
\hline $6 \mathrm{~A}$ & $\$ S^{2} \mathrm{~V}^{2} S^{2} \$$ & $\mathrm{w}^{2} \check{\gamma} \mathrm{j}^{2}$ & Falar, palavra \\
\hline
\end{tabular}


Tabela 3 - Continuação da página anterior

\begin{tabular}{|c|c|c|c|}
\hline Código & Segmento/Contexto & Transcrição & Tradução (PB) \\
\hline $7 \mathrm{~A}$ & $\hat{\mathrm{V}}$ & $\mathrm{w}^{2} \hat{\gamma}$ & Abelha \\
\hline $7 \mathrm{~B}$ & $\check{\mathrm{V}}$ & lǎj? & Pescar, anzol \\
\hline $8 \mathrm{~A}$ & $\mathrm{~V}$ & $\mathrm{w}^{2} \mathrm{en}$ & Sucuri \\
\hline $8 B$ & $\mathrm{~V}$ & dej$^{?}$ & Torto \\
\hline- & - & $\operatorname{coj}^{2}$ & Louva-deus \\
\hline- & - & $b_{j j}{ }^{2}$ & Arrotar \\
\hline $9 \mathrm{~A}$ & S? & jẽm?eh & Rezar \\
\hline- & - & Pãh com Pêj & Eu vou tomar banho \\
\hline- & - & 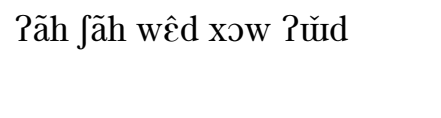 & $\begin{array}{l}\text { Eu acho que vou comer só pi- } \\
\text { menta }\end{array}$ \\
\hline $10 \mathrm{~A}$ & iS & mẽ 1 mỗ & Uma poça, um inambu \\
\hline- & - & wa? nã & O gavião voa \\
\hline- & - & nũ? wrt & Outro dia \\
\hline- & - & nõ̃Pjỗh & Medicar (dar remédio) \\
\hline $11 \mathrm{~A}$ & $S^{2} ?$ & $w^{2} \gamma j^{2} P a$ & Gaguejar \\
\hline- & - & $w^{2} \gamma_{j}^{2} P \hat{\gamma} j$ dǒ? & Responder \\
\hline $12 \mathrm{~A}$ & $\mathrm{PS}^{?}$ & $\mathrm{~m} \tilde{\varepsilon} 2 \mathrm{~m} 2 \hat{\tilde{\tilde{J}}}$ & Uma lontra, uma irara \\
\hline- & - & $\mathrm{m} \tilde{\varepsilon} ? \mathrm{w}^{2} \mathrm{an}$ & Um cará-do-mato \\
\hline $13 \mathrm{~A}$ & $\mathrm{SS}^{2}$ & Pãm ñãm & Você é perigoso \\
\hline $14 \mathrm{~A}$ & $S^{2} S$ & xôl? jum & A criança grande está viva \\
\hline- & - & xôl? lan & A criança grande fez coivara \\
\hline- & - & $\mathrm{w}^{2} \tilde{\mathrm{i}} \mathrm{n}^{2} \mathrm{j} \gamma \mathrm{w}$ & Cansar \\
\hline- & - & $x u b w^{2} \gamma j^{2}$ măm? & Dialogar \\
\hline $15 \mathrm{~A}$ & $S^{2} S^{?}$ & $x \hat{l^{2}}{ }^{2} \mathrm{n}^{2} a ̃ m$ & A criança grande é perigosa \\
\hline- & - & $w^{2} \check{\gamma} j^{2} j^{2} a ̌ h$ & Enganar \\
\hline $16 \mathrm{~A}$ & ?? & wřP ?ãm & Você escutou? \\
\hline- & - & nẵ? Pãh tûw & Este é o seu caminho \\
\hline- & - & tih ?ẫ pǔd jed bõhõ ju? ?uj & $\begin{array}{l}\text { Ela dorme muito, porque o } \\
\text { fogo está quente }\end{array}$ \\
\hline $17 \mathrm{~A}$ & $\mathrm{PO}$ & wr?křt & Pisar \\
\hline- & - & do?cah & Pintar de preto \\
\hline- & - & to? cugg pǔd ha? & $\begin{array}{l}\text { Minha barriga está doendo } \\
\text { muito }\end{array}$ \\
\hline $18 \mathrm{~A}$ & $\mathrm{O} ?$ & Juk PǎP & Vasilha (lata) de farinha \\
\hline- & - & mřc ?ว்̃t & O curupira chora \\
\hline 19A & $\mathrm{OO}$ & tekcah & Barrear (encher de barro) \\
\hline- & - & mřc ka ăm & O curupira morre \\
\hline $20 \mathrm{~A}$ & $\mathrm{~S}^{2} \mathrm{O}$ & běl ${ }^{2} \mathrm{krw}$ & Pedaço de vela \\
\hline
\end{tabular}


Tabela 3 - Continuação da página anterior

\begin{tabular}{|c|c|c|c|}
\hline Código & Segmento/Contexto & Transcrição & Tradução (PB) \\
\hline- & - & $\int e{ }^{2}{ }^{2}$ cuk & O pirarucu pula \\
\hline- & - & 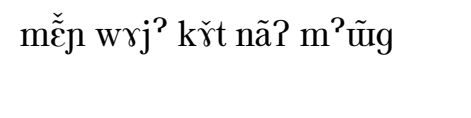 & $\begin{array}{l}\text { Fique aqui vigiando no meu } \\
\text { lugar }\end{array}$ \\
\hline $21 \mathrm{~A}$ & $\mathrm{OS}^{?}$ & făk m ${ }^{2} \tilde{u}^{?}$ & Subir com você \\
\hline- & - & $\begin{array}{l}\text { tih hõk wº̂o dřh mrn băk } \\
\text { nüxx wr? }\end{array}$ & $\begin{array}{l}\text { Ele cortou o cacho de inajá } \\
\text { para cair em cima do curupira }\end{array}$ \\
\hline $22 \mathrm{~A}$ & SO & tumcẵ? & Piscar \\
\hline $23 \mathrm{~A}$ & OS & tuk m $\check{\tilde{i} \int}$ & Quero um jabuti \\
\hline- & - & Jǔk ja? & Jogar no fogo \\
\hline $24 \mathrm{~A}$ & Redução silábica & ?ãm & Você \\
\hline $24 \mathrm{~B}$ & Redução silábica & tih & Ele \\
\hline $24 \mathrm{C}$ & Redução silábica & $m^{2} \hat{\tilde{\varepsilon}} J$ & Seu \\
\hline $24 \mathrm{D}$ & Redução silábica & $\operatorname{tih} \hat{\tilde{\varepsilon}} J$ & Dele \\
\hline $24 \mathrm{E}$ & Redução silábica & 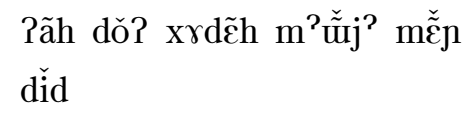 & Eu não vou levar você comigo \\
\hline- & - & 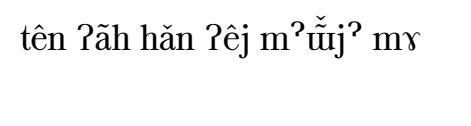 & $\begin{array}{l}\text { Agora eu vou mostrar para } \\
\text { você o cará da caatinga }\end{array}$ \\
\hline $24 \mathrm{G}$ & Redução silábica & 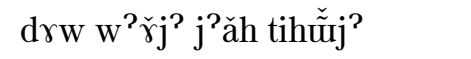 & Enganaram-no \\
\hline $25 \mathrm{~A}$ & $\$ \mathrm{k}$ & kăl? & Arara \\
\hline $25 \mathrm{~B}$ & $\$ \mathrm{k}$ & kob & Descascar \\
\hline $25 \mathrm{C}$ & $\$ c$ & cugẽ̃h & Não dói \\
\hline $25 \mathrm{D}$ & $\$ c$ & cid & Lavar \\
\hline
\end{tabular}

As palavras e frases que se encontram no material de gravação mostrado na tabela 3 foram selecionadas para a realização de nove análises diferentes, dividas em cinco tipos: análises fundamentais, análises complementares, análises de fatores não-linguísticos, análise qualitativa e estudo da redução silábica. As análises fundamentais, tratadas no capítulo 4 e no capítulo 5 , incluem (i) a comparação das consoantes simples e glotalizadas, (ii) dos diferentes tipos de glotalização e (iii) estudos sobre o alcance da glotalização em segmentos adjacentes e como as propriedades fonéticas da glotalização se manifestam no eixo temporal. As análises complementares, que podem ser conferidas na seção 8.1 e no capítulo 6, têm o propósito de verificar se algum fator linguístico favorece ou interage com uma das formas da glotalização. Os fatores considerados são (iv) a nasalidade e (v) os tons lexicais. As análises de fatores não-linguísticos assemelham-se às análises complementares, mas os fatores considerados são (vi) faixa etária e (vii) sexo, ambos examinados na seção 8.2. A análise qualitativa, realizada na seção 7.2, compreende (viii) a avaliação das oclusivas glotais em contraste com as propriedades da glotalização. Por fim, (ix) o estudo da redução silábica, feito na seção 7.1, tem o propósito de avaliar em 
termos fonéticos este processo descrito por Martins (2004).

\subsubsection{Equipamentos}

Nas sessões de gravação, utilizou-se um gravador Zoom H4nSP em conjunto com o microfone unidirecional, mono e balanceado Shure WH20XLR. O gravador interpretou o canal 2 do microfone como um canal estéreo, portanto, com o software Praat, o sinal deste canal foi invertido (multiplicação por -1) e, em seguida, combinado com o sinal do canal 1, de tal maneira que se obtiveram arquivos de áudio mono com cancelamento de ruído.

\subsubsection{Participantes}

Na coleta de dados de 2014, participaram 5 falantes nativos da língua Dâw e de português brasileiro, sendo uma do sexo feminino ( $\mathrm{DL}^{13}$ ) e quatro do sexo masculino (JR, OC, MT e WD). Três dos cinco participantes - DL, MT e WD - foram novamente requisitados para a coleta de dados seguinte, conforme se verifica na tabela 4. Nas sessões de gravação realizadas em 2015, participaram 11 falantes nativos da língua Dâw e de PB. Encontravam-se entre os participantes seis pessoas do sexo feminino e cinco pessoas do sexo masculino; três com idade abaixo dos 20 anos, seis com idade entre 20 e 50 anos e dois com idade acima dos 50 anos, havendo pelo menos um representante de ambos os sexos em cada faixa etária. A tabela 4 resume as informações sobre os participantes da coleta de dados de 2015.

\begin{tabular}{|c|c|c|}
\hline Identificação & Idade & Sexo \\
\hline TT & abaixo dos 20 & feminino \\
\hline ES & entre 20 e 50 & feminino \\
\hline $\mathrm{NZ}$ & entre 20 e 50 & feminino \\
\hline SL & entre 20 e 50 & feminino \\
\hline SV & entre 20 e 50 & feminino \\
\hline DL & acima dos 50 & feminino \\
\hline $\mathrm{JN}$ & abaixo dos 20 & masculino \\
\hline VT & abaixo dos 20 & masculino \\
\hline MT & entre 20 e 50 & masculino \\
\hline $\mathrm{PD}$ & entre 20 e 50 & masculino \\
\hline WD & acima dos 50 & masculino \\
\hline
\end{tabular}

\subsubsection{Procedimentos}

As sessões de gravação realizadas em 2015 ocorreram em um local silencioso. No primeiro dia (5 de julho), participaram TT e SV; no segundo dia (6 de julho), JN e MT; no terceiro dia (7 de julho), DL, SL e ES; no quarto dia (8 de julho), VT, PD e NZ; e, no último dia (9

\footnotetext{
13 Neste trabalho, os falantes da língua Dâw são sempre referidos por um código de duas letras.
} 
de julho), WD, JN e MT, estando presentes os dois últimos para gravações complementares. Nas sessões de gravação, a haste e a fita do microfone unidirecional foram colocadas na parte posterior da cabeça e atrás das orelhas e o microfone foi posicionado $25 \mathrm{~mm}$ à direita da boca dos participantes, conforme especificado no manual do aparelho. O autor deste trabalho deixou o gravador próximo a si mesmo para operá-lo quando fosse necessário e para verificar se não havia nenhum problema com a gravação. Explicou-se aos participantes que eles deveriam pronunciar a palavra/frase em Dâw correspondente à que fosse enunciada (tradução para o PB). Utilizou-se conjuntamente a lista de palavras/frases e a ficha do participante, seguindo a ordem dos códigos de identificação desta e consultando aquela para obter a palavra correspondente. Quando o participante alegava desconhecer a palavra/frase ou apresentava uma palavra/frase diferente da esperada, pronunciava-se a forma em Dâw que constava na lista e perguntava-se se ele a conhecia. Em caso positivo, o participante era instruído a pronunciá-la. Em alguns casos, os participantes corrigiram a tradução para o PB, o que era incorporado nas sessões seguintes. Se o falante afirmava ainda desconhecer a forma apresentada, passava-se à palavra/frase alternativa ou ao código seguinte. Terminada a ficha, caso o participante não houvesse pronunciado nenhuma das palavras/frases alternativas, solicitava-se que o fizesse, a fim de aumentar o volume do corpus. 


\section{2}

\section{A definição da glotalização nas taxonomias dos tipos de fonação}

As articulações produzidas com estruturas laríngeas e os modos de fonação constituem um tópico ainda pouco compreendido em todos os ramos da fonética (NÍ; GOBL, 1999), sobretudo se for comparado ao estudo das articulações supralaríngeas, que consolidou descrições e modelos mais amplos e precisos (EDMONDSON; ESLING, 2006). Entretanto, existem propostas teóricas abrangentes e um corpo de informações razoável sobre as propriedades acústicas e articulatórias dos sons de fala que possuem articulações laríngeas específicas e tipos de fonação não-modal. Neste capítulo, são resenhadas três abordagens do tema (ver seção 2.1) e discutidos os termos "glotalização" e "laringalização", mencionando as suas várias acepções e a definição empregada nesta pesquisa (ver seção 2.2). Embora muitos trabalhos possam ser mencionados, a discussão da seção 2.1 atém-se às formulações teóricas encabeçadas por Peter Ladefoged, John Laver e John Esling, porque aplicam-se a dados de natureza linguística - especialmente os trabalhos de Peter Ladefoged e John Esling -, tratam de diferentes aspectos do assunto e têm um alcance considerável na área.

\subsection{Três sistemas de classificação dos tipos de fonação}

Apesar de não se restringir ao campo linguístico, a abordagem de John Laver parece ser muito apropriada para a descrição de vários sons que ocorrem nas línguas do mundo. $\mathrm{Na}$ fundamentação do seu sistema classificatório, o autor identifica três tipos de tensão aplicados sobre as pregas vocais: tensão longitudinal, tensão adutora e compressão medial (LAVER, 1980, p. 108-109). A tensão longitudinal relaciona-se com a ação dos músculos tireoaritenoideo interno e cricotireoideo, que comprimem e alongam as pregas vocais, respectivamente. A tensão adutora e a compressão medial participam da adução das pregas vocais em áreas distintas. A tensão adutora provém da ação dos músculos interaritenoideos e causa o fechamento da glote cartilaginosa. A compressão medial obstrui a glote ligamentar por meio da contração dos músculos cricoaritenoideos laterais, com o auxílio do músculo tireoaritenoideo externo. A figura 1 mostra em quais lugares essas forças são exercidas e o seu sentido. $\mathrm{O}$ autor classifica todos os modos de fonação de acordo com os três tipos de tensão aplicados às pregas vocais. 
Figura 1 - Três tipos de tensão aplicáveis às pregas vocais segundo Laver (1980)

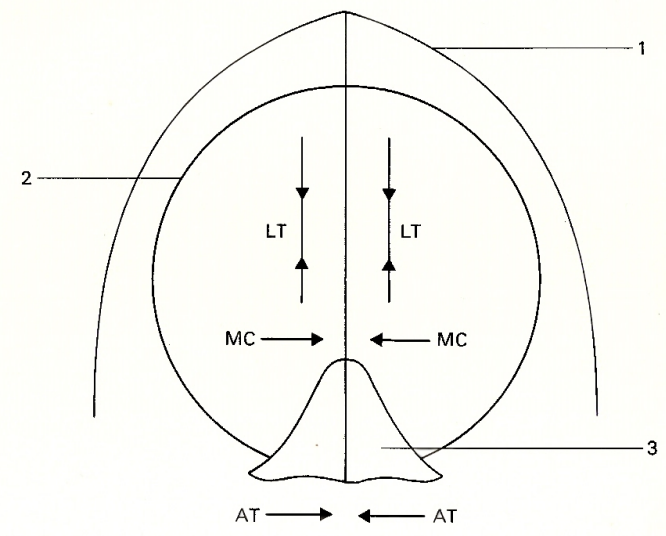

Figura extraída de Laver (1980)

Legenda:

1 - Cartilagem tireoide, 2 - Glote, 3 - Cartilagens aritenoides, LT - Tensão longitudinal, MC - Compressão medial, AT - Tensão adutora

Laver (1980) define modos de fonação simples e compostos com a distribuição hierárquica do diagrama da figura 2. Em primeiro lugar, Laver (1994) descreve a condição de não-fonação ou fonação nula, que consiste na ausência de energia acústica no nível glotal e inclui dois estados possíveis: fechamento completo e constante da glote (oclusão glotal) ou abertura constante da glote sem fluxo de ar turbulento (LAVER, 1994, p. 187-189). O estado de abertura glotal constante sem fluxo de ar turbulento classifica-se como desvozeamento, categoria da qual participa ainda a soprosidade (ou fonação soprosa). Laver (1980) considera a soprosidade, cujo efeito acústico consiste em um leve ruído de fricção, como uma modificação aplicável à fonação, em vez de um tipo de fonação próprio (LAVER, 1994, p. 112 e 132). A fonação soprosa é produzida com as pregas vocais amplamente abduzidas (tensão adutora e compressão medial baixas) e com um volume de fluxo de ar pulmonar alto e turbulento (LAVER, 1980; LAVER, 1994). A fonação sussurrada soa de maneira semelhante à fonação soprosa, mas o ruído de fricção é muito mais intenso (LAVER, 1994, p. 190). As pregas vocais desenvolvem maior adução na fonação sussurrada do que na fonação soprosa (compressão medial alta e tensão adutora baixa) e a glote reduz-se a uma pequena área triangular na região posterior da laringe. Ao contrário da soprosidade, a fonação sussurrada pode ocorrer sozinha, portanto Laver (1980) a define como um tipo de fonação simples (LAVER, 1994, p. 112).

A voz modal, expressão cunhada por Harry Hollien (LAVER, 1980, p. 95), é o modo neutro de vibração das pregas vocais, que se utiliza como o termo de comparação e diferenciação para todos os outros (LAVER, 1980, p. 94-95). Laver (1980) sintetiza a definição da voz modal como o modo de fonação em que a vibração das pregas vocais verdadeiras é periódica, eficiente e sem fricção audível, produto de tensão adutora e compressão medial moderadas (LAVER, 1980, 
Figura 2 - Tipos de fonação simples e compostos de acordo com Laver (1994)

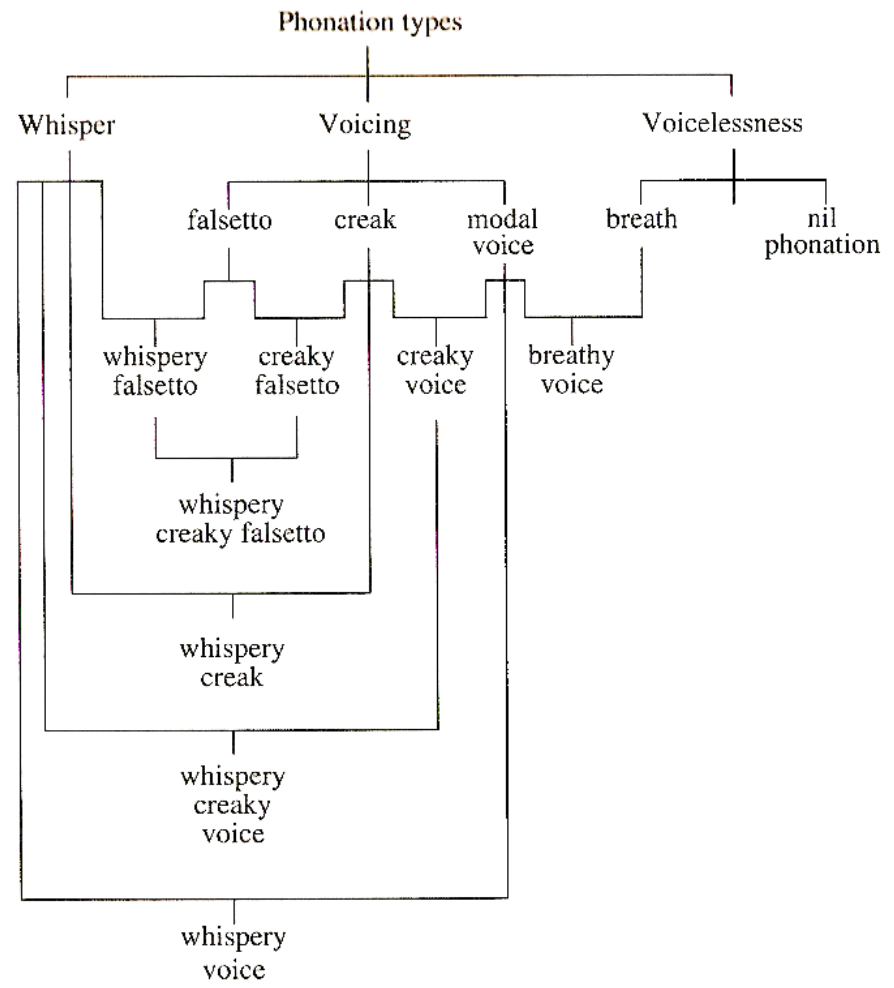

Figura extraída de Laver (1994)

Traduções dos termos utilizadas neste trabalho:

whisper - fonação sussurrada, whispery voice - voz sussurrada, voicing vozeamento, falsetto - fonação em falsete, creak - fonação rangeada, modal voice - voz modal, creaky voice - voz rangeada, breath - soprosidade, breathy voice - voz soprosa, voicelessness - desvozeamento, nil phonation - fonação nula

p. 94 e 111). Os outros dois tipos de fonação simples e vozeados são o falsete e o rangeado. A fonação em falsete define-se por tensão longitudinal, tensão adutora e compressão medial altas. A característica mais importante do falsete é a subida da faixa de frequência fundamental, que, para um indivíduo do sexo masculino, salta em média de 94 a 287 Hz para 275 a 634 Hz (HOLLIEN; MICHEL, 1968 apud LAVER, 1980, p. 602). Ao contrário da fonação em falsete, a fonação rangeada, também denominada vocal fry e glottal fry (LAVER, 1980, p. 122), caracteriza-se por uma faixa de frequência fundamental baixa, com média de 34,6 Hz (LAVER, 1980, p. 122). Quando se produz a fonação rangeada, o controle da frequência fundamental parece ser feito não por ajustes musculares (tensão longitudinal), mas por alterações na pressão do ar subglotal (LAVER, 1980, p. 123-124). Os períodos fundamentais, correspondentes a um ciclo glotal, têm geralmente durações muito irregulares (LAVER, 1994, p. 195). A fonação rangeada é produzida com tensão adutora e compressão medial muito altas, mas tensão longitudinal baixa. As pregas ventriculares parecem ainda participar da fonação rangeada: pressionadas às pregas vocais, as 
pregas ventriculares formam com aquelas uma massa espessa de vibração (HOLLIEN et al., 1966 apud LAVER, 1980, p. 247) e a sua ação pode causar o amortecimento do movimento das pregas vocais (LAVER, 1980, p. 124-125). Em termos auditórios, a fonação rangeada é definida como uma série rápida de batidas, semelhantes às de um bastão correndo por um trilho (CATFORD, 1964 apud LAVER, 1980, p. 32). Este tipo de fonação inclui, além disso, uma subcategoria em que os pulsos glotais são dicróticos (LAVER, 1980, p. 124-125).

Laver (1980) não considera a aspereza, assim como a soprosidade, como um tipo de fonação próprio, mas como uma modificação de tipos de fonação (LAVER, 1980, p. 126-132). Laver (1994) compreende a aspereza como um grau de tensão aumentado de toda a estrutura laríngea, em relação ao grau de tensão comum à fonação modal. Entre os tipos de tensão definidos anteriormente, a tensão adutora e a compressão medial ocupam um lugar proeminente na produção da aspereza: ambas são observadas em grau extremo (LAVER, 1980, p. 130). Semelhante à fonação rangeada, a voz áspera caracteriza-se acusticamente por valores de jitter $^{1}$ altos (LAVER, 1980, p. 127-128) e, na dimensão fisiológica, pelo envolvimento das pregas ventriculares, ao menos nos casos mais severos (LAVER, 1980, p. 130). Por outro lado, a voz áspera não é realizada, em geral, com frequências fundamentais baixas (LAVER, 1980, p. 122). Do ponto de vista da impressão auditória gerada, a aspereza adiciona uma qualidade rascante, rugosa e metálica à voz (LAVER, 1980; LAVER, 1994). A voz áspera também se define por alto nível de ruído espectral, irregularidade na forma de onda e shimmer ${ }^{2}$ aumentado (LAVER, 1980, p. 127).

Dentre os tipos de fonação compostos definidos nos trabalhos de Laver, interessa a esta pesquisa apenas a voz rangeada, que consiste na combinação da fonação rangeada com a voz modal. Laver (1980, p. 139) menciona a variabilidade intersubjetiva da voz rangeada e observa que o mecanismo fisiológico exato ainda precisa ser explorado. $\mathrm{O}$ autor levanta a possibilidade de que a distinção auditória de dois componentes, um modal e o outro rangeado, possa ser um artefato e que a qualidade de som denominada voz rangeada possa ser simplesmente um subtipo da fonação rangeada, em vez de um tipo de fonação composto (LAVER, 1994, p. 195).

Peter Ladefoged oferece uma taxonomia dos modos de fonação um pouco distinta, porém compatível em termos gerais com a de John Laver. A abordagem de Peter Ladefoged concentrase apenas nos tipos de fonação que têm relevância linguística, portanto, modos de fonação como a fonação em falsete não são considerados. No lugar dos três tipos de tensão considerados por Laver (1980), Gordon e Ladefoged (2001) localizam os tipos de fonação em uma escala contínua de adução das pregas vocais (ou fechamento da glote), o que subsume a tensão adutora e a compressão medial. Como se observa na figura 3, a extremidade esquerda (maior abertura glotal) da escala é marcada pela abertura constante da glote e a extremidade direita (menor abertura glotal) pela oclusão glotal. Cabe lembrar que estes são os estados glotais que John Laver compreende sob o termo "fonação nula". Equidistante de ambas as extremidades, ou seja, situada no meio da escala, encontra-se a voz modal, que Ladefoged e Maddieson (1996)

Medida da variação da duração dos ciclos glotais.

2 Medida da variação da amplitude da forma de onda dos ciclos glotais. 
e Gordon e Ladefoged (2001) descrevem de maneira semelhante a Laver (1980) e empregam também como termo de comparação para os outros tipos de fonação. Imediatamente ao lado da extremidade esquerda, encontra-se assinalada a voz soprosa, que, segundo correspondência estabelecida por Laver (1980, p. 139), equivale à voz sussurrada na terminologia deste. Em posição simétrica, situa-se a voz rangeada, que pode ser entendida como a fonação rangeada no sistema descritivo de Laver (1980). Ladefoged e Maddieson (1996) distinguem ainda graus intermediários entre a voz modal e a voz soprosa - a voz frouxa (slack voice) - e entre a voz modal e a voz rangeada - a voz rígida (stiff voice).

Figura 3 - Demarcação dos tipos de fonação em uma escala contínua de fechamento da glote de acordo com Gordon e Ladefoged (2001)

Phonation type $\begin{array}{llll}\text { Most open } & \text { Voiceless } & \text { Breathy } & \text { Modal closed } \\ \text { Greaky } & \text { Glottal closure }\end{array}$

Figura extraída de Gordon e Ladefoged (2001, p. 384)

Traduções dos termos utilizadas neste trabalho:

voicelessness - desvozeamento, breathy - voz soprosa, modal - voz modal, creaky - fonação rangeada, glottal closure - fechamento completo da glote

Gordon e Ladefoged (2001) mencionam segmentos produzidos com níveis de tensão variados, denominados relaxados (lax) e tensos (tense). Esta descrição é compatível com a escala de tensão geral da fonação proposta por Laver (1994), que compreende níveis baixos (relaxados) e altos (tensos), sendo a soprosidade e a aspereza graus maiores de relaxamento e tensão, respectivamente (LAVER, 1994, p. 418-420). A tensão longitudinal, um dos parâmetros levados em conta na proposta de Laver (1980), não encontra equivalência em Ladefoged e Maddieson (1996) e Gordon e Ladefoged (2001). Nos trabalhos mencionados de John Laver, a tensão longitudinal é importante sobretudo para distinguir a fonação em falsete, que, como dito, não é discutida nos estudos de Peter Ladefoged. Supõe-se que a escolha de Peter Ladefoged reflete a sua preocupação, já comentada, em focalizar o uso linguístico dos tipos de fonação, deixando em segundo plano ou mesmo desconsiderando tipos de fonação empregados apenas nos níveis paralinguístico e extralinguístico. Entretanto, Gordon e Ladefoged (2001) não desconsideram a frequência fundamental na caracterização de cada tipo de fonação discutido, pelo contrário. Gordon e Ladefoged (2001) relacionam várias propriedades acústicas recorrentes nos modos de fonação que discutem. Os trabalhos de Ladefoged e Maddieson (1996) e Gordon e Ladefoged (2001) são importantes não apenas por causa da proposta de classificação dos tipos fonatórios, mas também pela discussão dos sons observados em muitas línguas do mundo e por oferecer meios práticos (fonéticos) de identificação desses sons de fala.

Os trabalhos de John Esling e seus coautores sobressaem-se pela descrição detalhada, feita a partir de exames de imagem, da produção das articulações laríngeas. A descrição precisa da ação das estruturas laríngeas na articulação de alguns sons de fala sustenta a proposição de que a 
laringe é um articulador complexo (EDMONDSON; ESLING, 2006, p. 157-159). Em contraste com as abordagens de Peter Ladefoged e John Laver, voltadas, basicamente, à glote e às estruturas relacionadas, Edmondson e Esling (2006) analisam o denominado "articulador laríngeo" em seis mecanismos ou válvulas. A válvula 1 corresponde ao nível da glote e compreende a atividade das pregas vocais, que podem ser aduzidas, abduzidas (movimentos latero-mediais) e alongadas (movimento antero-posterior) (EDMONDSON; ESLING, 2006, p. 160-161). O processo constritivo da válvula 2 sucede-se quando as pregas vocais já se encontram aduzidas (válvula 1). As pregas ventriculares pressionam as pregas vocais, amortecendo a sua vibração e reforçando o fechamento da glote (EDMONDSON; ESLING, 2006, p. 161-162). A válvula 3 desempenha a constrição ariepigloto-epiglotal. As cartilagens aritenoides e as pregas associadas as pregas ariepiglóticas - realizam um fechamento esfinctérico sobre o plano glotal, inserindo-se nas margens da epiglote. As estruturas responsáveis pela ação da válvula 3 encontram-se acima do plano glotal/ventricular. A direção da constrição ariepigloto-epiglotal forma um ângulo reto com a direção do fechamento das válvulas 1 e 2 . A glote pode manter-se aberta durante a ação da válvula 3, o que resulta em sons desvozeados (EDMONDSON; ESLING, 2006, p. 162).

As válvulas 4, 5 e 6 parecem desempenhar um papel menor na produção dos sons de fala estudados nesta pesquisa. A válvula 4 produz retração da língua e da epiglote, que também se abaixa, em direção às paredes da cavidade faríngea. A válvula 5 controla o movimento vertical da laringe, especialmente a subida da laringe, embora também lhe possa ser atribuído o abaixamento. A válvula 6 realiza a constrição das paredes da cavidade faríngea, estreitando-a (EDMONDSON; ESLING, 2006, p. 159). Em resumo, a válvula 1 é responsável principalmente pelo vozeamento. As válvulas 2 e 3, sobretudo a última, afetam fortemente a qualidade da fonação. Por fim, as válvulas 4, 5 e 6 modificam a cavidade de ressonância faríngea (EDMONDSON; ESLING, 2006, p. 162).

Edmondson e Esling (2006) classificam a laringalização como um registro ou modo de fonação que compreende a fonação rangeada e a voz áspera (EDMONDSON; ESLING, 2006, p. 169-171). Na produção da fonação rangeada, as pregas vogais (válvula 1) tornam-se frouxas, o que provoca maior ondulação durante as vibrações, e há constrição intensa das pregas ariepiglóticas (válvula 3) (EDMONDSON; ESLING, 2006, p. 169). A voz áspera produzida com frequência fundamental alta ${ }^{3}$ caracteriza-se pela forte constrição das válvulas 1 e 2, com pouca ação das pregas ariepiglóticas (válvula 3). É importante ressaltar que o alongamento das pregas vocais se opõe ao mecanismo de fechamento do esfíncter ariepiglótico (EDMONDSON; ESLING, 2006, p. 169). A ação da válvula 2, ausente na fonação rangeada e presente na voz áspera, também ocorre durante a articulação da oclusiva glotal, como um meio de comprimir as pregas vocais e amortecer a sua vibração (EDMONDSON; ESLING, 2006; ESLING; HARRIS, 2003). Ainda segundo os autores, a voz áspera é produzida com retração da língua (válvula 4), elevação da laringe (válvula 5) e, geralmente, estreitamento da cavidade faríngea (válvula 6)

3 Segundo Edmondson e Esling (2006), a voz áspera possui variedades com frequência fundamental baixa, média e alta, que se diferenciam perceptual e articulatoriamente. 
(EDMONDSON; ESLING, 2006, p. 172). Edmondson e Esling (2006, p. 171) avaliam que a fonação rangeada e a voz áspera têm muitos traços em comum, o que levou alguns linguistas a considerá-las como um único modo de fonação. A relação entre a fonação rangeada e a voz áspera também pode ser observada no domínio diacrônico, como nas línguas da família Tibeto-Birmanesa: enquanto a língua Birmanesa apresenta fonação rangeada, palavras cognatas da língua Yi exibem voz áspera (EDMONDSON; ESLING, 2006, p. 171).

Além da quantidade e da natureza dos níveis de articulação e de ação possíveis, as três propostas apresentam algumas diferenças. Por exemplo, Peter Ladefoged e John Esling não definem, como John Laver, modos de fonação simples e compostos. John Laver defende que as pregas ventriculares desempenham um papel importante na fonação rangeada, enquanto John Esling não assinala a constrição da válvula 2 neste tipo de fonação. As definições de aspereza e voz áspera para os dois autores também parecem ser diferentes. Na seção 4.4, comparou-se a capacidade das três propostas teóricas discorridas em oferecer subsídios adequados e suficientes para a análise e a descrição das consoantes glotalizadas da língua Dâw.

\subsection{Os significados dos termos "glotalização" e "laringalização"}

$\mathrm{Na}$ literatura linguística, existe grande variação terminológica com respeito às configurações ou articulações laríngeas que envolvem constrição intensa. Os termos "laringalização" e "glotalização", bem como os seus derivados adjetivais, são particularmente problemáticos.

O termo "glotalização" designa fenômenos fonéticos muito variados, como o uso de mecanismo de ar glotálico - empregado na produção de consoantes ejetivas e implosivas -, a fonação rangeada e unidades fonêmicas constituídas de uma oclusiva glotal e um segmento oral ou nasal. No trabalho de Martins (2004), por exemplo, é possível encontrar a palavra "glotalização" com as três acepções mencionadas. O termo "laringalização" também é empregado com mais de um sentido nos trabalhos que tratam do tema. Ladefoged e Maddieson (1996) usam os termos "voz rangeada" e "laringalização" como sinônimos. Blankenship (1997), por sua vez, define a voz rangeada como um subtipo da laringalização. Para Blankenship (1997), a laringalização é um tipo de fonação em que as pregas vocais são mantidas rígidas e a vibração é parcialmente inibida, enquanto a voz rangeada caracteriza-se especificamente por pulsos dicróticos e impressão auditória de rangeado. Esling, Fraser e Harris (2005) relacionam as diferentes denotações da palavra "glotalização" encontradas na literatura: em suma, os linguistas têm empregado o termo "glotalização" para se referir a segmentos produzidos com fonação rangeada parcial ou total e/ou acompanhados imediatamente de uma oclusiva glotal, formando uma única unidade fonêmica (ESLING; FRASER; HARRIS, 2005, p. 389).

Laver (1994) define a laringalização como uma articulação secundária que consiste em uma tendência articulatória a produzir maior constrição glotal (LAVER, 1994, p. 330). Desta maneira, a laringalização não se restringe apenas à fonação rangeada, mas também abrange outros eventos fonéticos em que uma articulação oral (primeira articulação) é acompanhada por uma constrição 
glotal aumentada (segunda articulação). Por exemplo, de acordo com a definição de Laver (1994, p. 330), um som de fala observado por Roach (1979 apud LAVER, 1994) que envolve adução das pregas vocais, ventriculares e ariepiglóticas, além de elevação da laringe, pode ser identificado como laringalizado. A definição de "laringalização" de Edmondson e Esling (2006), mencionada na seção anterior deste capítulo, assemelha-se à de Laver (1994, p. 330), mas apresenta maior exatidão.

A fim de manter a tradição descritiva das línguas Nadahup, este trabalho emprega o termo "glotalização" com o sentido dado ao termo "laringalização" por Edmondson e Esling (2006) Aproximando as transcrições aqui utilizadas às de Martins (2004), adota-se o símbolo de oclusiva glotal sobrescrita $\left(\mathrm{S}^{2}\right)$ para transcrever a glotalização na língua Dâw. Cabe ressaltar, no entanto, que a oclusiva glotal sobrescrita é colocada sempre após o segmento associado e que o posicionamento do símbolo não tem relação com a sequência dos eventos articulatórios, ao contrário do uso sugerido em Martins (2004).

4 Na seção 4.4, demonstra-se que a definição de Edmondson e Esling (2006) é adequada para designar a glotalização na língua Dâw. 


\section{3}

\section{O papel da glotalização no sistema fonológico}

O inventário de fonemas consonantais da língua Dâw é formado por consoantes vozeadas e desvozeadas que têm pontos e modos de articulação variados. Ao contrário do que ocorre em algumas línguas, como o português brasileiro, há fonemas consonantais da língua Dâw que não se definem apenas pela ausência ou presença de vozeamento, por ponto e por modo de articulação. As palavras /mỗ / e $/ \mathrm{m}^{2} \hat{\tilde{\partial}} /$, que significam em português, respectivamente, "inambu" e "irara", têm a mesma vogal e o mesmo tom de contorno (descendente). A diferença limita-se à consoante presente no ataque silábico. Embora ambas as palavras tenham uma consoante nasal (modo de articulação) e bilabial (ponto de articulação), há um conjunto de características que permite distingui-las e considerá-las como fonemas diferentes. Quando se compara a figura 4 com a figura 5, notam-se algumas diferenças acústicas nas consoantes mencionadas, especialmente o nível de irregularidade relativamente mais alto na forma de onda dos ciclos glotais da consoante $/ \mathrm{m} \%$, visível no oscilograma (A) da figura 5. Não se trata, contudo, de uma propriedade restrita a um fonema apenas. Outros pares de palavras demonstram a existência desta possibilidade de distinção em outras consoantes vozeadas. Por exemplo, as palavras /laj/ ("formiga”) e /lă:j”/ ("anzol") têm a mesma consoante inicial (1), a mesma vogal e tons diferentes. Como mostram as figuras 6 e 7, há algumas características acústicas visivelmente distintas nas consoantes $/ \mathrm{j} / \mathrm{e} / \mathrm{j}$ /, como, novamente, o nível mais alto de irregularidade na forma de onda dos ciclos glotais da parte final da consoante $/ \mathrm{j} \%$. Os casos apresentados demonstram que há duas classes de consoantes na língua Dâw que não se diferenciam por vozeamento, ponto ou modo de articulação, mas por outras características acústicas. As consoantes de uma das classes, denominada "simples" e exemplificada por $/ \mathrm{m} / \mathrm{e} / \mathrm{j} /$, assemelham-se às consoantes encontradas em línguas como o português brasileiro: são vozeadas e têm modo de fonação modal. As consoantes da outra classe, denominada "glotalizada" e exemplificada por $/ \mathrm{m}^{2} / \mathrm{e} / \mathrm{j}$ /, são também vozeadas, mas possuem tipos de fonação não-modal. As diferenças articulatórias e acústicas das consoantes simples e glotalizadas são tratadas de maneira mais detalhada nos capítulos 2 e 4 .

Martins (2004) coligiu 12 pares mínimos e análogos de consoantes simples e glotalizadas com o mesmo ponto e o mesmo modo de articulação (MARTINS, 2004, p. 20-22). O autor do presente trabalho regravou as palavras com 13 falantes nativos da língua Dâw (ver seção 1.2), 
Figura 4 - Oscilograma (A), espectrograma (B) e curva de frequência fundamental (C) da palavra /mỗ/ pronunciada por DL
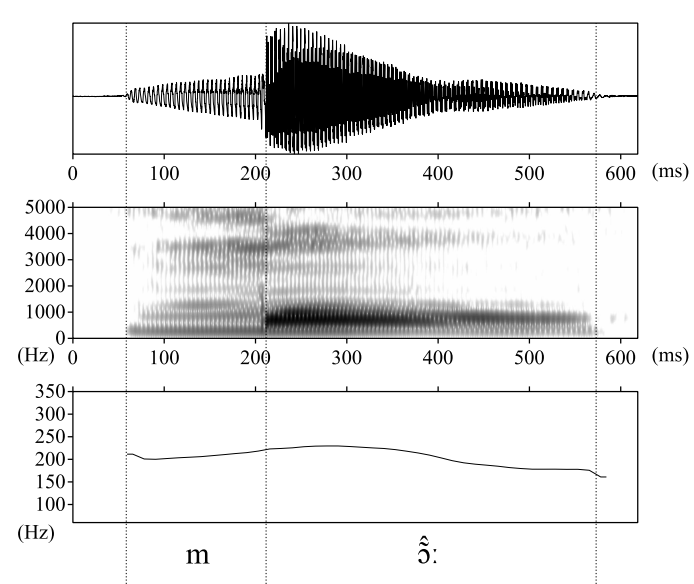

Figura 6 - Oscilograma (A), espectrograma (B) e curva de frequência fundamental $(C)$ da palavra /laj/ pronunciada por OC

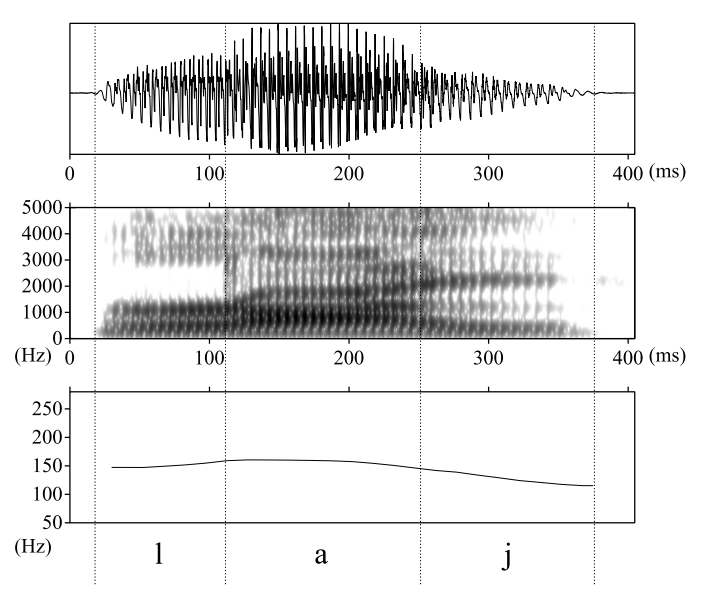

(B)

(A)

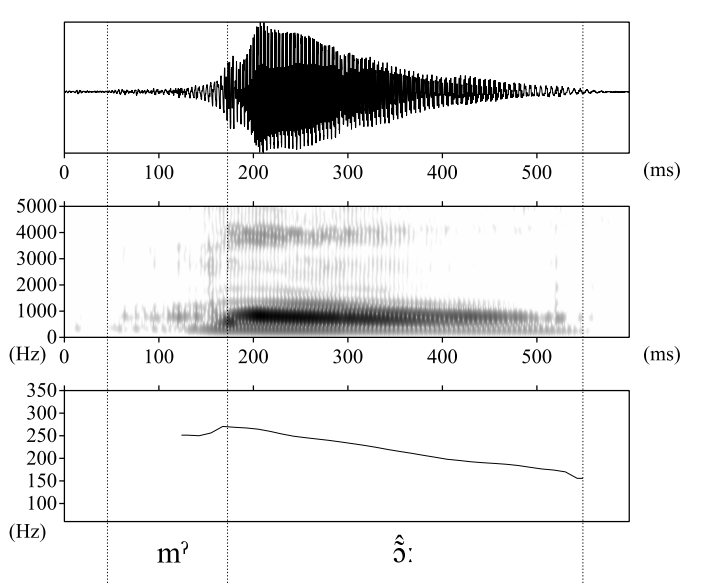

(A)

Figura 5 - Oscilograma (A), espectrograma (B) e curva de frequência fundamental $(C)$ da palavra $/ \mathrm{m}^{2} \hat{\tilde{\partial}} /$ pronunciada por DL

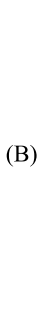

Figura 7 - Oscilograma (A), espectrograma (B) e curva de frequência fundamental $(C)$ da palavra $/$ lăj?/ pronunciada por OC

(A)

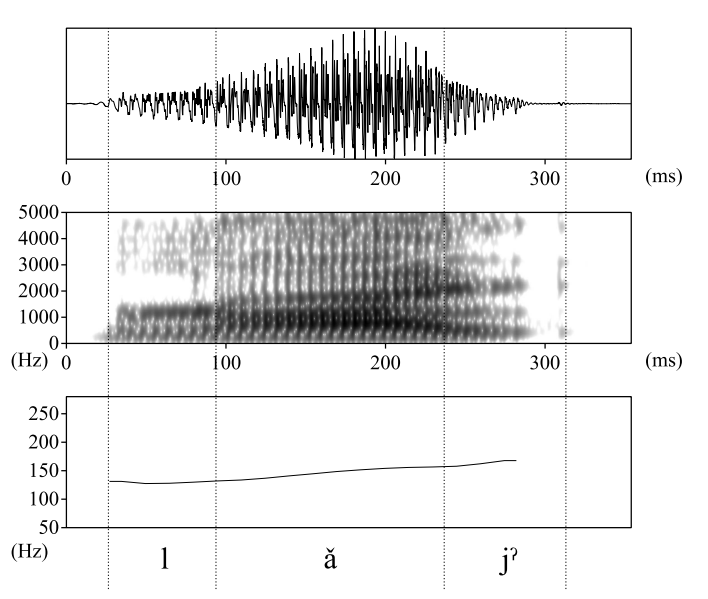

(A)

avaliou-as por meio da audição e analisou-as acusticamente. A despeito de algumas diferenças segmentais e tonais, obtiveram-se 9 pares mínimos e análogos, mostrados em cor preta na tabela $5^{1}$. O caráter fonêmico das consoantes glotalizadas é reforçado ainda pela variedade de contextos. Conforme descrito na subseção 1.1.1, a maioria das palavras da língua Dâw é monossilábica e tem estrutura silábica CVC. Desta maneira, as consoantes limitam-se, em quase todos os casos, a duas posições dentro da palavra e da sílaba: início de palavra/sílaba e fim de palavra/sílaba. A figura 8 representa o oscilograma (A) e a curva de frequência fundamental (B) da palavra $/ \mathrm{w}^{2} \mathrm{j}^{\mathrm{j}} /$, que possui duas consoantes glotalizadas: $/ \mathrm{w}^{2} / \mathrm{e} / \mathrm{j}^{2} /$. As mesmas consoantes podem ser vistas em posições diferentes, ou seja, $/ \mathrm{j}$ / em ataque silábico/início de palavra e $/ w^{2} /$ em coda silábica/fim de palavra nas palavras /j ${ }^{2}$ rn/ ("balançar o corpo como lagarta"),

1 Os pares de palavras com letras na cor vermelha não puderam ser gravados em campo ou foram pronunciados de maneira muito distinta da descrita por Martins (2004). 
mostrada na figura 9, e / $\mathrm{Paw}^{2} /$ (“mastigar"), mostrada na figura 10. As palavras presentes na tabela 5 também demonstram que as consoantes glotalizadas podem ocupar qualquer uma das duas posições.

Tabela 5 - Pares mínimos e análogos coligidos por Martins (2004)

\begin{tabular}{|c|c|c|c|c|}
\hline & \multicolumn{2}{|c|}{ Consoantes simples } & \multicolumn{2}{|c|}{ Consoantes glotalizadas } \\
\hline & Transcrição & Tradução (PB) & Transcrição & Tradução (PB) \\
\hline 1. & mỗ & inambu & $\mathrm{m}^{2} \tilde{\tilde{\tilde{J}}}$ & irara \\
\hline 2. & wâm & macaco cutiporó & w?ăm? & embaúba \\
\hline 3. & nẽk & açaí & tum $n^{2} \tilde{\varepsilon} \mathrm{k}$ & vesgo \\
\hline 4. & lon & sapo & $\operatorname{lon}^{2}$ & $\begin{array}{l}\text { enrolar linha de } \\
\text { pesca }\end{array}$ \\
\hline 5. & $\operatorname{lax}$ & cair & $1^{2} \mathrm{ax}$ & latir \\
\hline 6. & jah & fruta & $\mathrm{oj}^{?} \mathrm{ah}$ & mentir \\
\hline 7. & laj & formiga & $1 a j^{?}$ & pescar ou anzol \\
\hline 8. & wôj & abelha ou rato & $w^{2} \hat{\partial} j^{?}$ & voz do guariba \\
\hline 9. & law & cadáver & Paw $^{2}$ & mastigar \\
\hline 10. & xû̃..nz̃h & $\begin{array}{l}\text { não chuviscou em } \\
\text { casa }\end{array}$ & xũ̃..jp ${ }^{2} \mathrm{hh}$ & confira (imperativo) \\
\hline 11. & jẫ̄n & $\begin{array}{l}\text { andar envergado car- } \\
\text { regando frutas }\end{array}$ & jãn ${ }^{?}$ & $\begin{array}{l}\text { socar para caber mais } \\
\text { farinha }\end{array}$ \\
\hline 12. & xel & isqueiro & $x \check{i} l^{?}$ & sal \\
\hline
\end{tabular}

Notas:

Os pares de palavras em vermelho não puderam ser gravados em campo ou não são pares mínimos/análogos, pelo menos de acordo com a pronúncia atualmente usada pelos falantes

A transcrição das palavras apresentadas na tabela foram feitas pelo autor deste trabalho e divergem um pouco da de Martins (2004)

Como há palavras que têm consoantes glotalizadas em ataque silábico/início de palavra, coda silábica/fim de palavra ou em ambas as posições, supõe-se que a glotalização esteja associada a um segmento e não a entidades fonológicas maiores, como a sílaba. A palavra / $\mathrm{wrj}^{?}$ / (ver figura 19), que significa, em português, "ver", pode ser comparada à palavra $/ \mathrm{w}^{2} \check{\gamma}_{\mathrm{j}} \mathrm{T} /$, que significa, em português, "palavra" ou "falar"2. As duas palavras têm consoantes glotalizadas, porém apenas a segunda tem uma consoante glotalizada no ataque silábico. Embora as duas palavras tenham tons distintos, sabe-se que as consoantes $/ \mathrm{w} / \mathrm{e} / \mathrm{w}^{2} /$ são tratadas como consoantes diferentes porque os falantes não pronunciam $/ \mathrm{w}^{2} \mathrm{\gamma j}^{2} / \mathrm{com}$ o significado de "ver" ou $/ \mathrm{w}_{\mathrm{r} j}^{\mathrm{j}}$ / com o significado de "palavra". A análise acústica das alterações nas propriedades das consoantes glotalizadas e das vogais adjacentes no domínio do tempo, feita em detalhes no capítulo 5, demonstra que a glotalização se concentra com maior intensidade em uma parte das consoantes e que apenas algumas propriedades acústicas das vogais adjacentes são afetadas, como a frequência fundamental. Desta maneira, há evidências fonológicas e fonéticas para sustentar a tese de que a glotalização é uma propriedade segmental na língua Dâw.

\footnotetext{
2 A comparação fonética das duas palavras pode ser conferida no capítulo 4.
} 
Figura 8 - Oscilograma (A) e curva de frequência fundamental (B) da palavra $/ w^{2} \check{\gamma} \check{j}^{2} /$ pronunciada por SL

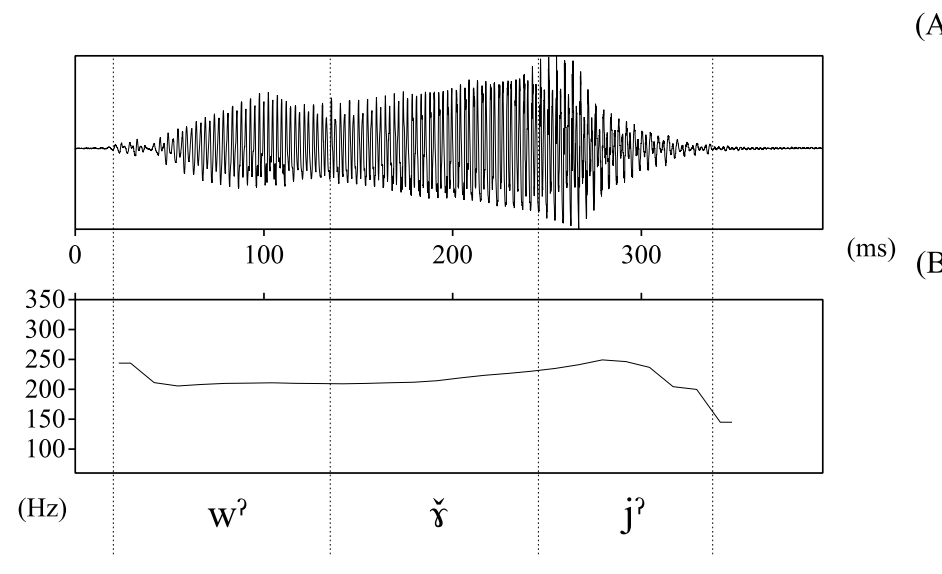

(A)

Quando se observam atentamente as palavras da tabela 5, percebe-se que todas as consoantes glotalizadas são segmentos vozeados, o que não causa muita surpresa, porque, como se discute nos capítulos 2 e 4, a glotalização, tal como definida na língua Dâw, pressupõe a fonação. No inventário das consoantes da língua Dâw (ver subseção 1.1.1), existem oclusivas vozeadas, mas, como mostram os exemplos da tabela 5, não há oclusivas glotalizadas ${ }^{3}$. Na língua Dâw, há somente fricativas desvozeadas e, por conseguinte, não há fricativas glotalizadas. Deste modo, a glotalização restringe-se às consoantes que pertencem à classe das soantes: as aproximantes palatal (j) e lábio-velar (w), a aproximante lateral alveolar (l) e as consoantes nasais bilabial (m), alveolar (n), palatal (n) e velar (y).

Figura 9 - Oscilograma (A), espectrograma (B) e curva de frequência fundamental $(C)$ da palavra $/ \mathrm{j}^{2} \mathrm{rn} /$ pronunciada por $\mathrm{PD}$
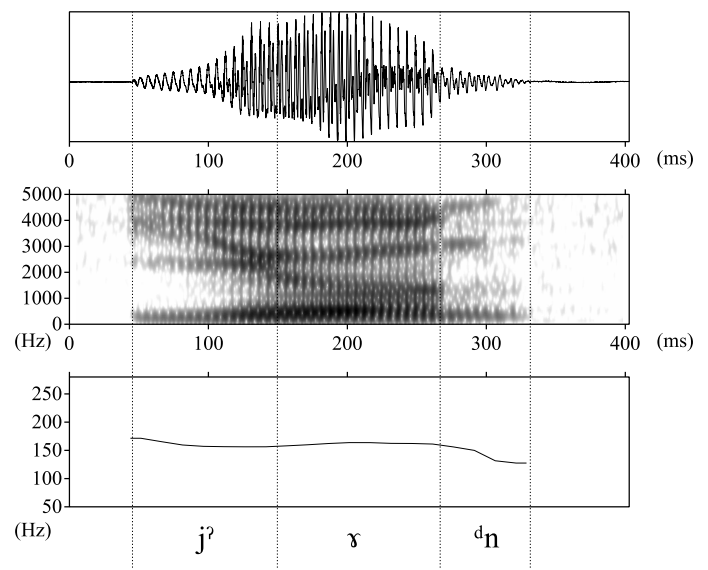

(A)
Figura 10 - Oscilograma (A), espectrograma (B) e curva de frequência fundamental $(\mathrm{C})$ da palavra $/$ ?aw $\%$ pronunciada por JR

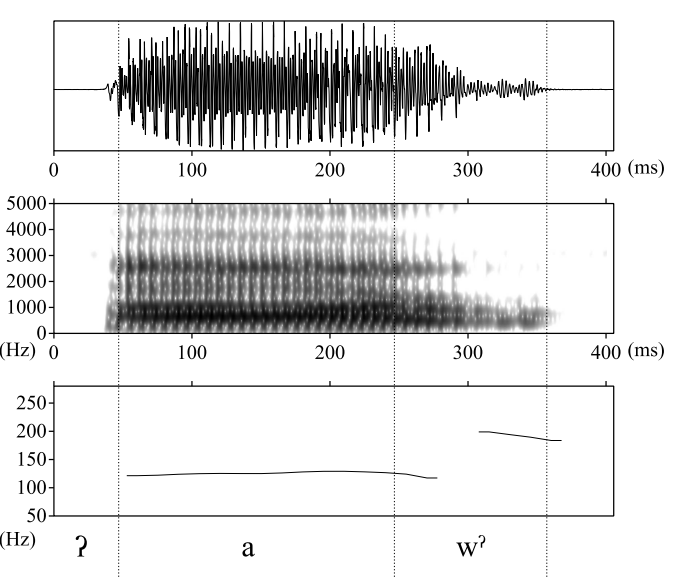

(A)

Na tabela 5, podem ser conferidos exemplos de consoantes glotalizadas com todos os modos e pontos de articulação relacionados no parágrafo anterior, exceto a nasal velar. Martins (2004)

3 Segundo Epps (2005), a língua Hup, outro membro da família Nadahup apresenta oclusivas glotalizadas (ver subseção 1.1.2). 
Figura 11 - Oscilograma (A), espectrograma (B) e curva de frequência fundamental (C) da palavra /bãy\%/ pronunciada por SL

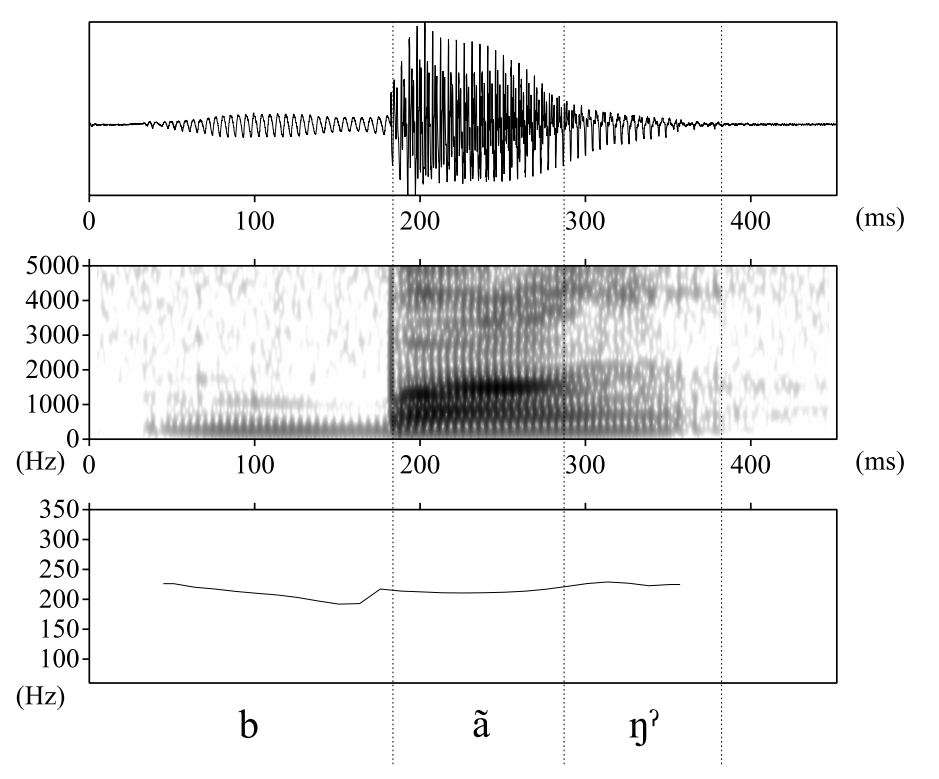

(A)

não menciona a nasal velar glotalizada no seu quadro de fonemas consonantais e nos exemplos de pares mínimos e análogos. No trabalho de campo realizado em 2015 para coleta de corpus para a presente pesquisa (ver seção 1.2), foi encontrada uma palavra que continha uma nasal velar glotalizada: /bãy\%, que significa "banco", em português. Trata-se, provavelmente, de uma palavra originária do português brasileiro, o que a torna ainda mais interessante, porque não há glotalização na língua portuguesa. Solicitou-se a vários falantes nativos da língua Dâw que pronunciassem a palavra e em todos casos constatou-se a presença da glotalização na consoante nasal velar. A figura 11 mostra o oscilograma (A), o espectrograma (B) e a curva de frequência fundamental (C) da palavra /bã $\%$. Observam-se redução na intensidade acústica e maior irregularidade na duração e na forma de onda dos ciclos glotais da parte final da consoante $/ \mathrm{y} \%$, assim como elevação da frequência fundamental no final da vogal /a/ e ao longo da consoante glotalizada, o que, como será visto nos capítulos 4 e 5, são características das consoantes glotalizadas com fonação rangeada.

A existência de nasais velares glotalizadas permite formular as seguintes proposições a respeito das restrições da glotalização na língua Dâw:

1. Todas as consoantes glotalizadas da língua Dâw pertencem à classe das soantes;

2. Na língua Dâw, existem consoantes glotalizadas com todos os modos e pontos de articulação possíveis para as consoantes da língua Dâw que pertencem à classe das soantes.

Este trabalho não pretende aprofundar-se em questões teóricas da fonologia, porém, cabe fazer uma breve discussão a respeito da natureza fonológica das consoantes glotalizadas da língua Dâw. As consoantes glotalizadas teriam, de acordo com a maioria das teorias fonológicas baseadas em traços, o traço [+constricted glottis] (HALL, 2007, p. 316-318), que é compartilhado 
com a oclusiva glotal e com as consoantes ejetivas e implosivas. O traço relaciona-se, em termos articulatórios, com a adução das cartilagens aritenoides, que faz as pregas vocais se pressionarem umas às outras e altera a sua vibração (HALLE; STEVES, 1971).

Moisik e Esling (2011) propõem um novo conjunto de traços para lidar com vários tipos de segmentos e articulações em que participam as estruturas laríngeas e aos quais comumente se atribuem traços como [ \pm constricted glottis], [ATR] etc. Os traços propostos pelos autores mencionados relacionam-se com diversos aspectos da articulação laríngea: ponto (glotal ou epilaríngeo), fonação (sem fonação, glotal, epilaríngea ou, ainda, glotal/epilaríngea) e altura da laringe (neutra, elevada ou abaixada). Além disso, reaproveitam-se os traços [ \pm stiff] e $[ \pm$ spread glottis] e introduz-se o traço [ \pm constricted epylaringeal tube] - abreviado como $[ \pm$ cet] - que substitui o tradicional [ \pm constricted glottis]. A substituição de [ \pm constricted glottis] por [ \pm cet] não se trata de uma mera mudança terminológica, porque o traço [ \pm cet] abrange a constrição de todas as válvulas do articulador laríngeo (ver capítulo 2) e agrupa um conjunto de segmentos e articulações laríngeas muito mais amplo. Por exemplo, o traço [+cet] pode se aplicar, dentre outros, a segmentos com voz áspera, tensa e rangeada e a segmentos faringalizados. Todavia, como a língua Dâw não possui consoantes faríngeas, vogais denominadas ATR ou segmentos com fonação epilaríngea, as diferenças entre os traços [ \pm constricted glottis] e [ \pm cet] não são muito relevantes para o seu sistema fonológico, se considerado isoladamente, pelo menos.

A redução silábica, descrita no capítulo 7 , consiste em uma evidência a favor de que a glotalização e as oclusivas glotais compartilham o mesmo traço. Quando um pronome com formato $\mathrm{PV}_{1} \mathrm{~S}$ é acrescido de alguns sufixos $\mathrm{V}_{2} \mathrm{C}_{1}$ específicos, a forma $\mathrm{PV}_{1} \mathrm{SV}_{2} \mathrm{C}_{1}$ pode ser reduzida para $S^{2} V_{2} C_{1}$. Se a glotalização e a oclusiva glotal tivessem traços distintos, não haveria motivo para surgir uma consoante glotalizada na forma reduzida, sobretudo porque isso ocorre somente nos casos em que uma oclusiva glotal ocupa o ataque silábico do pronome. Por outro lado, se o mesmo traço é compartilhado pela glotalização e pela oclusiva glotal, o surgimento da glotalização na consoante soante simples pode ser explicado pelo espalhamento ou pela assimilação do traço [+constricted glottis] ou [+cet] da oclusiva glotal pela consoante soante simples. Não foram observados outros processos fonológicos que pudessem justificar ou contradizer a hipótese de que a glotalização e a oclusiva glotal são definidas pelo mesmo traço, porém as semelhanças fonéticas entre a glotalização e a oclusiva glotal verificadas na seção 7.2 reforçam a hipótese.

A glotalização também pode ser debatida com outras perspectivas teóricas, como a Fonologia Articulatória (BROWMAN; GOLDSTEIN, 1992) e teorias baseadas em restrições articulatórias e perceptuais (KINGSTON, 1985; STERIADE, 1997; SILVERMAN, 1997). No capítulo 5, menciona-se, por exemplo, como a manifestação das propriedades acústicas da glotalização no domínio do tempo podem, a princípio, ser explicadas por esses quadros teóricos. De um ponto de vista fonológico, em vez de explicar o surgimento de consoantes glotalizadas na redução silábica por meio de espalhamento ou assimilação de traços, é possível compreendê-lo como o resultado da coexistência simultânea dos gestos laríngeos que definem a oclusiva glotal e 
dos gestos supralaríngeos das consoantes soantes em uma forma anterior à forma reduzida: PSVC (ver capítulo 7). Como não se conhecem na língua Dâw outros processos fonológicos que envolvem a oclusiva glotal e a glotalização, não há como argumentar a favor de uma abordagem ou outra. 



\section{4}

\section{Algumas propriedades fonéticas da glotalização}

Com fundamento na literatura existente sobre o tema, discutida no capítulo 2, e na avaliação das consoantes glotalizadas da língua Dâw, elaborou-se um estudo quantitativo para determinar se as diferenças observadas em algumas características acústicas das consoantes simples e glotalizadas são realmente significativas de um ponto de vista estatístico. Os resultados do estudo acrescentam informações novas e mais confiáveis à descrição fonética da glotalização na língua Dâw e podem contribuir, de alguma maneira, para tarefa semelhante em outras línguas, aparentadas ou de outras famílias linguísticas, que também têm segmentos glotalizados. Embora se limite à dimensão acústica, os resultados do estudo podem, ainda, ser discutidos à luz dos trabalhos que tratam da produção da glotalização, como será feito na seção 4.4.

Figura 12 - Oscilograma (A) e curva de frequência fundamental (B) da palavra /lax/ pronunciada por DL

(A)
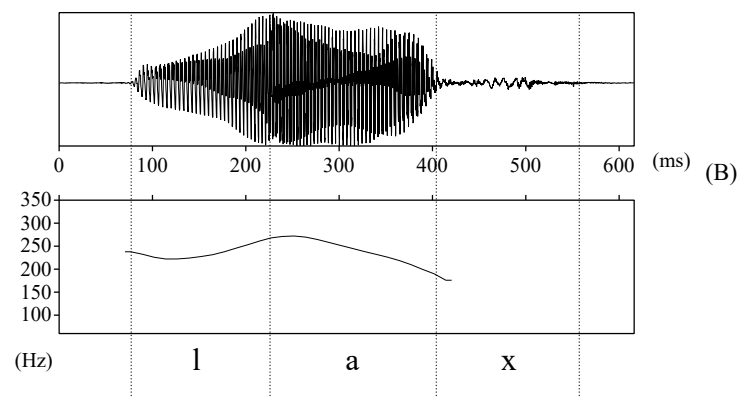

Figura 13 - Oscilograma (A) e curva de frequência fundamental (B) da palavra / $1^{2} \mathrm{ax} /$ pronunciada por DL

No capítulo 3, a glotalização foi descrita como uma propriedade distintiva aplicável a qualquer consoante da classe das soantes. Desta maneira, a comparação fonética entre consoantes simples e glotalizadas equivalentes, ou seja, que possuem o mesmo ponto e modo de articulação, deveria revelar as características fonéticas da glotalização. Ao fazê-lo, nota-se que os resultados das comparações impõem dificuldades à generalização. Comparem-se as figuras 12 e 13, que ilustram, respectivamente, as palavras /lax/ (“cair") e /1ªx/ ("latir"). Há diferenças muito claras nos oscilogramas (A) de ambas as palavras, algumas delas reforçadas pelos diagramas da curva de frequência fundamental (B). Contrastando apenas os intervalos que limitam as consoantes 
/1/ e $/ 1 \%$, vê-se que a regularidade na duração e na amplitude máxima dos ciclos glotais de /1/ não se repete em $/ 1^{?} /$, ao contrário: do início até próximo ao fim da consoante $/ \mathrm{I}^{?} /$, a duração e a amplitude máxima dos ciclos glotais são claramente irregulares. Como o cálculo da frequência fundamental depende de níveis altos de autocorrelação (ver seção 4.2), a curva de frequência fundamental (B) de /1/ é continua, enquanto / ${ }^{2}$ / não apresenta valores de frequência fundamental em quase toda a sua extensão. É possível observar também diferenças nas amplitudes relativas do primeiro e do segundo harmônico (H1 e H2, respectivamente) nos espectros FFT de ambas as consoantes. No espectro da consoante /1/ (ver figura 14), a amplitude de H1 é superior à de H2, de modo que $\mathrm{H} 1-\mathrm{H} 2$ resulta em 4, $7 \mathrm{~dB}$. A relação inversa é encontrada no espectro da consoante $/ 1^{2} /($ ver figura 15), em que a amplitude de $\mathrm{H} 1$ é inferior à de $\mathrm{H} 2$, sendo $\mathrm{H} 1-\mathrm{H} 2$ equivalente a $-4,6 \mathrm{~dB}$.

Figura 14 - Espectro FFT da consoante /1/ da palavra /lax/, representada na figura 12

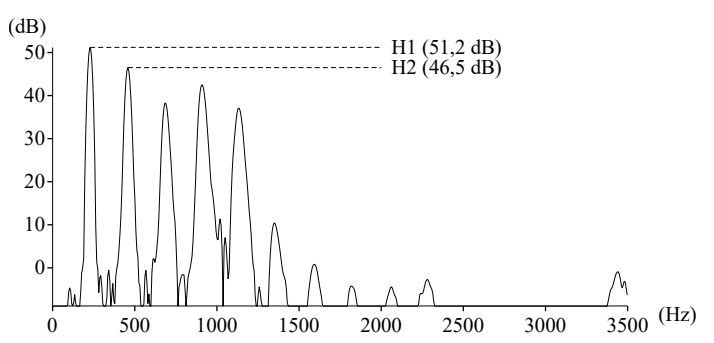

Figura 15 - Espectro FFT da consoante $/ 1^{2} /$ da palavra $/ 1^{2} \mathrm{ax} /$, representada na figura 13

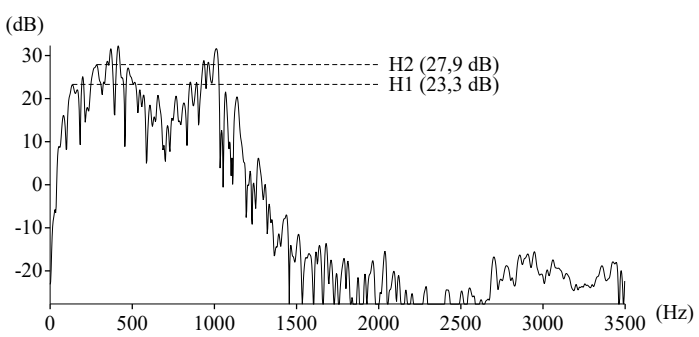

As diferenças acústicas de $/ 1 /$ e $/ 1^{2} /$ indicam que a consoante simples foi produzida com voz modal e que a consoante glotalizada apresenta fonação rangeada, podendo ser transcrita como [1], dadas as características de ambos os tipos de fonação discorridas no capítulo 2 e na seção 4.4. Considerando apenas este exemplo, a glotalização poderia ser definida simplesmente como fonação rangeada.

Figura 16 - Oscilograma (A) e curva de frequência fundamental (B) da palavra /mỗ̃/ pronunciada por JR

(A)

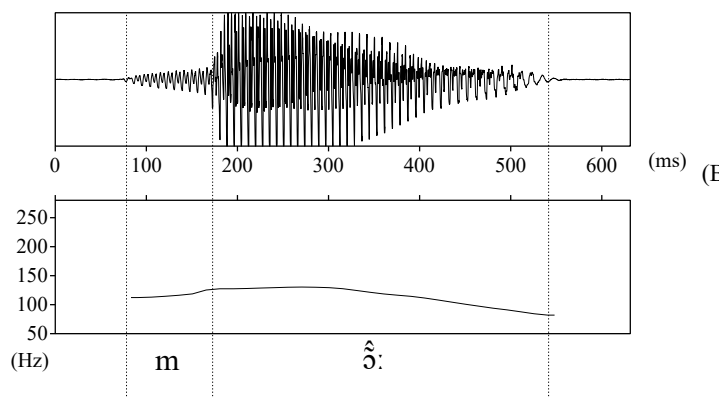

Figura 17 - Oscilograma (A) e curva de frequência fundamental (B) da palavra $/ \mathrm{m}^{2}$ วิ $/$ pronunciada por JR

(A)

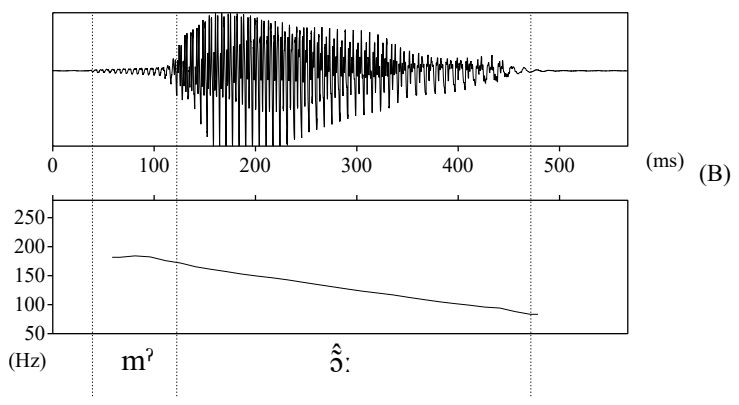

Ao comparar as figuras 16 e 17, notam-se também diferenças nas consoantes $/ \mathrm{m} / \mathrm{e} / \mathrm{m} \%$, contudo, não se tratam das mesmas diferenças observadas anteriormente. Os ciclos glotais da consoante $/ \mathrm{m}^{2}$ / não são muito mais irregulares - em duração, amplitude e forma de onda - do 
que os ciclos glotais da consoante $/ \mathrm{m} /$. Nos diagramas de frequência fundamental (B), ambas as consoantes apresentam valores ao longo de toda a sua duração, o que aponta para níveis relativamente altos de autocorrelação entre trechos sucessivos da forma de onda. Por outro lado, os níveis de frequência fundamental são bastante distintos: a frequência fundamental de $/ \mathrm{m}^{2} /$ é muito superior à de $/ \mathrm{m} /$, especialmente na parte inicial das consoantes.

Destacam-se características fonéticas diferentes nas consoantes glotalizadas $/ \mathrm{l}^{2} / \mathrm{e} / \mathrm{m}^{2} / \mathrm{dos}$ exemplos ilustrados. A audição atenta das palavras permite distinguir duas qualidades sonoras para a glotalização. Na consoante $/ 1 \%$, o som de rangeado pode ser facilmente identificado e, como descreve Catford (1964 apud LAVER, 1980, p. 32), lembra uma série rápida de batidas semelhantes às de um bastão correndo por um trilho. Na consoante $/ \mathrm{m}^{2} /$, não se ouve o som de rangeado, mas nota-se a voz áspera da descrição de Esling e Harris (2003, p. 1052), que soa como se um vozeamento com frequência fundamental alta fosse produzido de maneira forçada durante uma oclusão glotal.

\section{Figura 18 - Oscilograma (A) e curva de frequência funda- mental (B) da palavra $/ \mathrm{m}^{2} \hat{\tilde{\partial}} /$ pronunciada por WD}

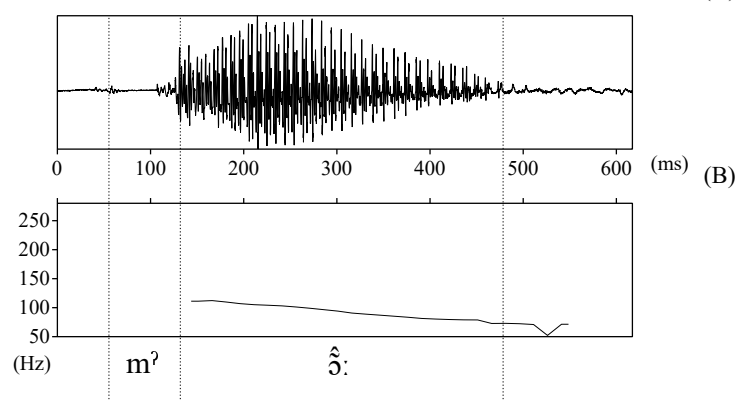

As consoantes comparadas no parágrafo anterior são exemplos típicos de duas formas da glotalização na língua Dâw - fonação rangeada e voz áspera -, mas há casos menos claros, cuja descrição não permite enquadrá-los com certeza em nenhuma das duas formas. Por exemplo, a consoante $/ \mathrm{m}^{2} /$ da palavra representada na figura 18 apresenta não apenas fonação rangeada, mas interrupção durante $43 \mathrm{~ms}$, indicando oclusão glotal completa durante esse intervalo de tempo. Por sua vez, a consoante $/ \mathrm{w}^{2} /$ da palavra mostrada na figura 20 possui pequena irregularidade no seu início, que não parece ser suficiente para caracterizar a fonação rangeada, e nível frequência fundamental que pouco se distingue do nível encontrado na consoante equivalente simples /w/ da palavra ilustrada na figura 19, consideradas as diferenças de tom em ambas as palavras. A consoante $/ \mathrm{m}^{2} /$ da figura 18 não pode ser descrita simplesmente como um segmento com fonação rangeada, porque há algo diferente que também a caracteriza, e a consoante $/ \mathrm{w}^{2} /$ da figura 20 não possui algumas propriedades da fonação rangeada - qualidade sonora e nível muito baixo de periodicidade - e da voz áspera - aumento de frequência fundamental.

A descrição detalhada das características acústicas de casos individuais de consoantes glotalizadas pode ser valiosa em um estudo que pretende desvendar os pormenores da produção desses sons ou mesmo em uma taxonomia dos tipos de fonação e de articulações laríngeas, mas, para as 
Figura 19 - Oscilograma (A) e curva de frequência fundamental (B) da palavra / $\mathrm{wrj}^{\mathrm{j}} /$ pronunciada por SL

(A)

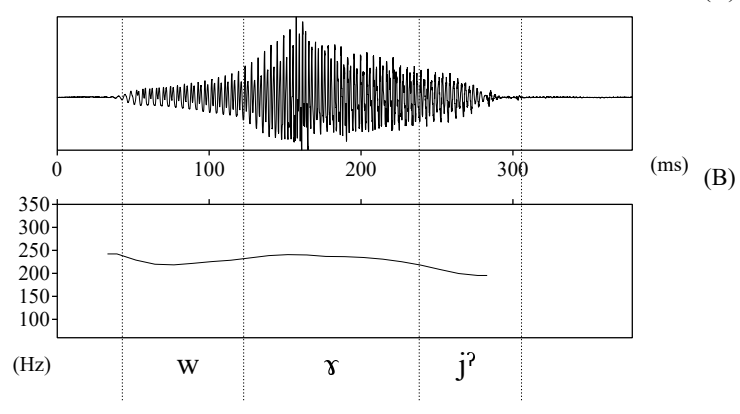

Figura 20 - Oscilograma (A) e curva de frequência fundamental (B) da palavra / $\mathrm{w}^{2} \check{\gamma} \mathrm{j} ? /$ pronunciada por SL

(A)

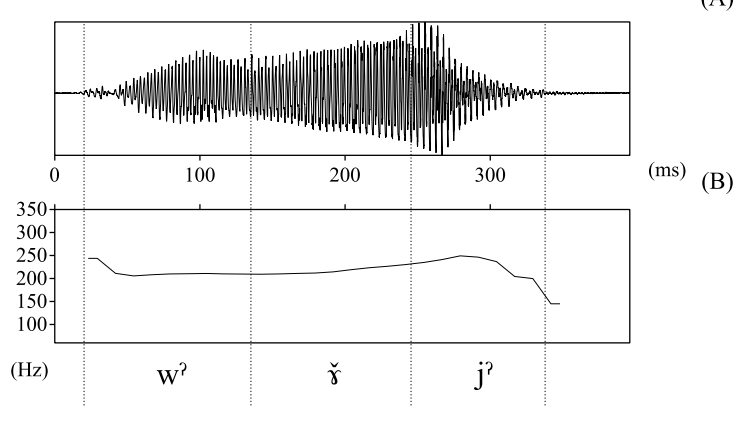

limitações de um estudo quantitativo feito com uma quantidade não muito grande de dados, a profusão de classes ou grupos pode prejudicá-lo, em vez de beneficiá-lo. Por outro lado, afirmouse que as consoantes glotalizadas com fonação rangeada e voz áspera têm algumas características claramente distintas: as suas propriedades principais não são as mesmas e as duas formas podem ser diferenciadas pela audição atenta sem muito esforço. Além disso, a propriedade mais importante das consoantes com fonação rangeada, o baixo nível de regularidade na forma de onda, interfere diretamente na aferição da propriedade mais relevante (frequência fundamental), a princípio, para as consoantes com voz áspera. Se todas as consoantes glotalizadas fossem incluídas em um mesmo grupo, sem fazer distinção das suas formas, os resultados do estudo quantitativo poderiam obscurecer características importantes, que não são equivalentes para as diferentes formas da glotalização. Como a divisão das consoantes glotalizadas entre fonação rangeada e voz áspera não é capaz de contemplar todos os casos, parece ser mais apropriado classificar as consoantes glotalizadas entre aquelas que apresentam rangeado e aquelas que não o apresentam, porque o critério de classificação é bem definido e porque isolam-se as consoantes com menor nível de periodicidade.

No restante deste capítulo, apresentam-se informações sobre o corpus do estudo (ver seção 4.1), as escolhas metodológicas a respeito das medições acústicas realizadas e do tratamento estatístico dos dados (ver seção 4.2), os resultados (ver seção 4.3) e a sua discussão (ver seção 4.4), levando em conta, sobretudo, a literatura examinada no capítulo 2.

\subsection{Descrição do corpus}

O corpus empregado neste estudo integra gravações (anotadas) realizadas em viagens de campo nos anos de 2014 e 2015, que foram descritas na seção 1.2. No corpus, há gravações feitas com 13 falantes nativos da língua Dâw, sendo seis do sexo feminino (DL, ES, NZ e SL, SV, TT) e sete do sexo masculino (JN, JR, MT, OC, PD, VT e WD) ${ }^{1}$. O corpus possui, ao todo, 360 palavras, incluindo repetições, e 400 segmentos relevantes para esta análise quantitativa. A

1 A faixa etária de 11 falantes pode ser conferida na subseção 1.2.3. 
tabela 6 colige todas as palavras presentes no corpus e reúne informações sobre a sua gravação. Note-se que os pares de palavras são pares mínimos ou análogos, em razão das exigências impostas pelo estudo (ver seção 4.2).

Tabela 6 - Informações sobre as palavras presentes no corpus do estudo quantitativo sobre as propriedades acústicas da glotalização

\begin{tabular}{|c|c|c|c|c|c|}
\hline & \multicolumn{2}{|c|}{ Consoantes simples } & \multicolumn{2}{|c|}{ Consoantes glotalizadas } & \multirow[t]{2}{*}{ Coleta } \\
\hline & Transcrição & Tradução (PB) & Transcrição & Tradução (PB) & \\
\hline 1. & $\mathrm{~m} \tilde{\tilde{\partial}}$ & inambu & $\mathrm{m}^{2} \hat{\tilde{\partial}}$ & irara & 2014,2015 \\
\hline 2. & wâm & macaco cutiporó & $\mathrm{w}^{2}$ ăm² & embaúba & 2014 \\
\hline 3. & nẽk & açaí & tum $n^{2} \tilde{\varepsilon} \mathrm{k}$ & vesgo & 2014 \\
\hline 4. & lon & sapo & $\operatorname{lon}^{?}$ & enrolar linha de pesca & 2014 \\
\hline 5. & $\operatorname{lax}$ & cair & $1^{?} \mathrm{ax}$ & latir & 2014 \\
\hline 6. & jah & fruta & $\mathrm{oj}^{3} \mathrm{ah}$ & mentir & 2014 \\
\hline 7. & laj & formiga & lǎj? & pescar ou anzol & 2014 \\
\hline 8. & wôj & abelha ou rato & $w^{2} \hat{\partial j}{ }^{?}$ & voz do guariba & 2014 \\
\hline 9. & law & cadáver & Paw $^{2}$ & mastigar & 2014 \\
\hline 10. & $w_{\gamma j}{ }^{2}$ & ver & $w^{2} \check{\gamma}_{j}^{2}$ & palavra & 2014,2015 \\
\hline
\end{tabular}

\subsection{Metodologia}

Baseado na literatura e em observações qualitativas, exemplificadas no início deste capítulo, foram selecionadas quatro propriedades acústicas para comparar as consoantes simples e glotalizadas: duração, frequência fundamental, periodicidade e $\mathrm{H} 1-\mathrm{H} 2$. Todas as quatro medidas variam em função de diferentes aspectos, linguísticos e não-linguísticos, da produção das consoantes, como: tipo de segmento, contexto segmental e suprassegmental, características subjetivas do falante, situação de fala etc. A variedade de segmentos, palavras e falantes garantem ao estudo maior amplitude, porém aumenta a variabilidade das medidas de tal modo que as torna incomparáveis entre si: não é possível, por exemplo, comparar a frequência fundamental de consoantes pronunciadas por falantes distintos. As diferenças nas propriedades acústicas das consoantes simples e glotalizadas são relativas, não absolutas. Deste modo, faz-se necessário comparar apenas segmentos simples e glotalizados contidos em palavras que oferecem contextos semelhantes e que foram pronunciadas pelos mesmos falantes, no mesmo contexto de gravação. Esta necessidade determinou o conteúdo a ser gravado, que consiste em uma lista de pares mínimos e análogos, como dito na seção 4.1. Do ponto de vista da preparação do corpus e da análise estatística dos dados, esta necessidade levou à adoção de grupos pareados e à aplicação de um teste que possibilitasse a análise pareada dos grupos.

Na língua Dâw, o inventário fonológico compreende consoantes simples e glotalizadas e, como dito anteriormente, estas podem ou não apresentar fonação rangeada. Os dados deste estudo estão divididos em três grupos: consoantes simples, consoantes glotalizadas com rangeado 
e consoantes glotalizadas sem rangeado. Todavia, os três grupos não podem ser pareados, porque os dois últimos são definidos por diferentes formas fonéticas de uma mesma entidade fonológica e as gravações não foram feitas mediante nenhum tipo de intervenção, como "pronuncie a consoante $\mathrm{X}$ da maneira Y", por razões de ordem prática e para assegurar maior naturalidade. $\mathrm{O}$ pareamento só pode ser feito entre consoantes simples e consoantes glotalizadas com rangeado e entre consoantes simples e consoantes glotalizadas sem rangeado. Havendo pareamento entre dois grupos, em vez de três, e sendo estritamente necessário o pareamento para a relevância dos resultados, não é possível aplicar um teste que compare diretamente os dados dos três grupos. Por esta razão, foram aplicados dois testes t para cada medida acústica.

A descrição e a análise estatística dos dados foram feitas automaticamente por meio de rotinas escritas para o software $R$, que executou os cálculos a partir de tabelas que continham as medidas extraídas pelo software Praat. Para a rejeição da hipótese nula de que não havia diferença entre as medidas dos grupos pareados em comparação, adotou-se como critério $p$ $<0,01$. O tamanho de efeito $d$ de Cohen também foi calculado, utilizando-se as médias e os desvios-padrão dos grupos pareados.

Para a realização do estudo descrito neste capítulo, procedeu-se, em primeiro lugar, à preparação do corpus, descrito na seção 4.1. Os arquivos de som produzidos durante as sessões de gravação foram inspecionados individualmente para verificar se o seu conteúdo condizia com o plano do teste e se a sua qualidade de áudio era adequada à análise acústica. Desprezaram-se, para a realização deste estudo, as pronúncias que divergiam do esperado, ou seja, que não eram das palavras necessárias ao estudo (por exemplo, o falante pronunciou um sinônimo da palavra esperada) e que não continham os segmentos ou atributos que se pretendiam analisar (por exemplo, o falante pronunciou uma forma abreviada, sem a consoante glotalizada). Considerado o conteúdo adequado, extraíram-se as palavras e as frases dos arquivos de gravação originais, identificando-as pelo código do falante (duas letras), do item e da repetição (crescente, iniciando na letra "a"). Como os grupos eram pareados, incluíram-se no corpus quantidades iguais de repetições para os dois itens de cada par, sendo desconsideradas as repetições excedentes.

Tendo sido preparado o corpus, fez-se a sua anotação, necessária para a aferição das medidas acústicas. Identificaram-se, somente por meio da sua audição, sem o auxílio de informações do oscilograma e do espectrograma, para evitar circularidade, e rotularam-se os segmentos relevantes e o seu tipo de fonação por meio de arquivos TextGrid do software Praat. Todos os procedimentos de extração das medidas acústicas foram realizados de maneira automática por meio de uma rotina do software Praat desenvolvida exclusivamente para este trabalho. $\mathrm{O}$ procedimento de medição de $\mathrm{H} 1-\mathrm{H} 2$ foi baseado em uma rotina de Chad Vicenik ${ }^{2}$.

Como se espera, a medição da duração consistiu simplesmente em obter a diferença em tempo (em milissegundos) das duas extremidades de um intervalo, definido no arquivo TextGrid, correspondente ao segmento em análise. Para a frequência fundamental, considerou-se a média

2 Disponível em <http://www.linguistics.ucla.edu/faciliti/facilities/acoustic/PraatVoiceSauceImitator.txt>. Acessado pela última vez em 30/01/2016 às 13:52. 
(em $\mathrm{Hz}$ ) de todo o segmento marcado, utilizando o algoritmo de autocorrelação (BOERSMA; WEENINK, 1993) e os valores padrão dos parâmetros do software Praat, exceto pelos valores dos parâmetros mínimo (floor) e máximo (ceiling), que foram ajustados de acordo com o sexo do falante: para homens, mínimo de $50 \mathrm{~Hz}$ e máximo de $280 \mathrm{~Hz}$ e, para mulheres, mínimo de 60 Hz e máximo de $350 \mathrm{~Hz}$.

Em um espectro FFT de todo o segmento considerado, a localização do primeiro e do segundo harmônico (H1 e H2) no eixo da frequência espectral foi obtida a partir do valor da frequência fundamental. Definiu-se a amplitude de $\mathrm{H} 1$ como o pico de energia $(\mathrm{dB})$ do espectro em um intervalo compreendido por valores $10 \%$ inferiores e $10 \%$ superiores em torno do valor da frequência fundamental. A amplitude de $\mathrm{H} 2$ foi calculada da mesma maneira, substituindo o valor da frequência fundamental pelo dobro do valor da frequência fundamental. Por fim, foi obtida a diferença entre as amplitudes H1 e H2 (em dB) a partir da subtração dos valores já determinados.

A aferição do nível de periodicidade de um segmento não é tão clara e simples como medição das outras propriedades mencionadas, porque a periodicidade do sinal acústico relaciona-se com diversos aspectos da produção da fala (e até mesmo da sua gravação) e porque existem várias medidas de periodicidade aplicáveis. Neste estudo, pretendem-se analisar os níveis de periodicidade que dizem respeito exclusivamente à fonação e à produção de som na região da laringe. Como são contrastados sons de fala gerados com a mesma configuração supralaríngea ${ }^{3}$, pelos mesmos falantes e nas mesmas condições de gravação, compreende-se que as diferenças nos níveis de periodicidade do sinal acústico decorrem, pelo menos em grande parte, da fonação. Desta maneira, o estudo não parece ser afetado pelo primeiro problema. Resta, contudo, examinar as diferentes medidas de periodicidade. Jitter e shimmer são duas medidas muito comuns na avaliação clínica da voz e tratam de dois aspectos distintos do sinal acústico: variabilidade da duração e da amplitude dos períodos fundamentais (ciclos glotais hipotéticos), respectivamente. Apesar de lidarem com aspectos bem definidos do sinal acústico e de serem aplicáveis à avaliação da fonação, não são medidas adequadas para todos os tipos de sons de fala e têm melhor aplicação em avaliações clínicas feitas a partir de gravações de vogais sustentadas. A análise cepstral, por outro lado, não possui tais restrições, podendo ser aplicada a diferentes tipos de segmentos, mas não lida de maneira adequada com as irregularidades da fonação rangeada (BLANKENSHIP, 1997, p. 10). Um dos indícios mais confiáveis da irregularidade no sinal acústico provocada pelo rangeado é a incapacidade de reconhecimento da frequência fundamental por algoritmos de autocorrelação, como o do software Praat. Os níveis de autocorrelação concernem ao grau de semelhança entre dois trechos sucessivos da forma de onda. A irregularidade no sinal acústico introduzida por alteração na fonação resulta na queda dos níveis de autocorrelação. Assim como os índices de autocorrelação são adequados para determinar a frequência fundamental de qualquer tipo de segmento vozeado, eles podem ser utilizados para determinar o nível de periodicidade, relacionado com a fonação (ASHBY; PRZEDLACKA, 2014), para qualquer tipo

\footnotetext{
3 Para efeito de simplificação, desconsiderem-se as possíveis interações entre os níveis laríngeo e supralaríngeo.
} 
de segmento. Pelos motivos alegados, neste trabalho, o nível de periodicidade considerado para cada segmento relevante foi definido como o seu nível de autocorrelação.

\subsection{Resultados}

Ao comparar as médias de duração das consoantes simples e glotalizadas nos dois grupos pareados, ou seja, o grupo de consoantes simples e glotalizadas com rangeado e o grupo de consoantes simples e glotalizadas sem rangeado, observa-se que as consoantes glotalizadas são mais curtas do que as suas correspondentes simples (ver figura 21). Os valores de desvio-padrão, representados pelas hastes verticais no centro das barras, são consideravelmente altos, porque os grupos contêm consoantes diferentes e a pronúncia de vários falantes. Em menor ou maior grau, todas as medidas, salvo periodicidade, apresentam níveis altos de desvio-padrão. Conforme discutido na seção 4.2, o problema da variabilidade dos dados foi resolvido com a adoção de grupos pareados e de um teste estatístico capaz de comparar tais grupos (teste t). Além disso, embora os desvios-padrão mostrem que há quantidade razoável de sobreposição em intervalos de valores de duração das consoantes simples e glotalizadas, os desvios-padrão são semelhantes para as consoantes simples e glotalizadas pertencentes a um mesmo grupo, o que garante que a sobreposição seja menor nos intervalos de valores de duração mais baixos das consoantes glotalizadas e nos intervalos de valores duração mais altos das consoantes simples ${ }^{4}$.

Figura 21 - Comparação das médias de duração (em milissegundos) de consoantes simples e glotalizadas de grupos pareados, com marcação dos desvios-padrão

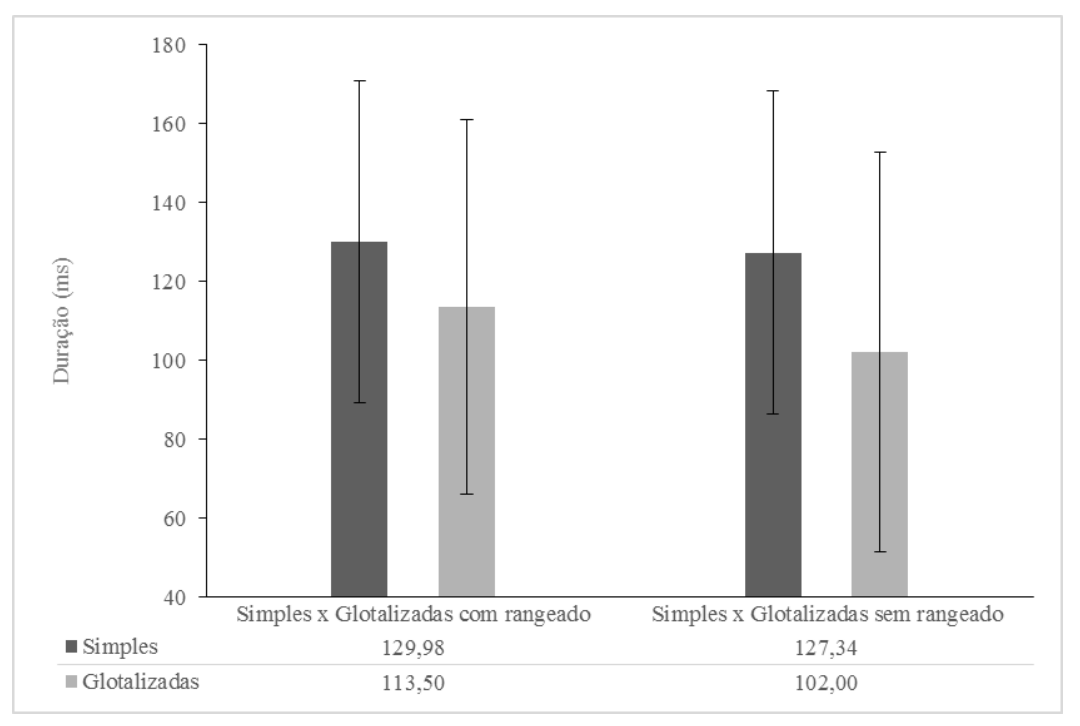

Na figura 21, vê-se que as diferenças entre as consoantes simples e glotalizadas são mais acentuadas para o grupo pareado de consoantes simples e glotalizadas sem rangeado $(25,34 \mathrm{~ms}$ contra 16, $48 \mathrm{~ms}$ ). O resultado do teste estatístico, apresentado conjuntamente com as diferenças estatísticas na tabela 7, confirma que há diferenças significativas nas médias de duração das consoantes simples e glotalizadas do grupo de consoantes simples e glotalizadas com rangeado

\footnotetext{
4 Pressupõe-se que os dados têm distribuição normal.
} 
$(\mathrm{t}=3,15, \mathrm{p}=0,002)$ e do grupo de consoantes simples e glotalizadas sem rangeado $(\mathrm{t}=4,49, \mathrm{p}<$ $0,001)$. Os valores de $d$ de Cohen apontam ainda para um tamanho de efeito pequeno $(0,37)$ para a diferença nas médias de duração das consoantes simples e glotalizadas do grupo de consoantes simples e glotalizadas com rangeado e um tamanho de efeito médio $(0,55)$ para a diferença nas médias de duração das consoantes simples e glotalizadas do grupo de consoantes simples e glotalizadas sem rangeado.

Figura 22 - Comparação das médias de frequência fundamental (em Hz) de consoantes simples e glotalizadas de grupos pareados, com marcação dos desvios-padrão

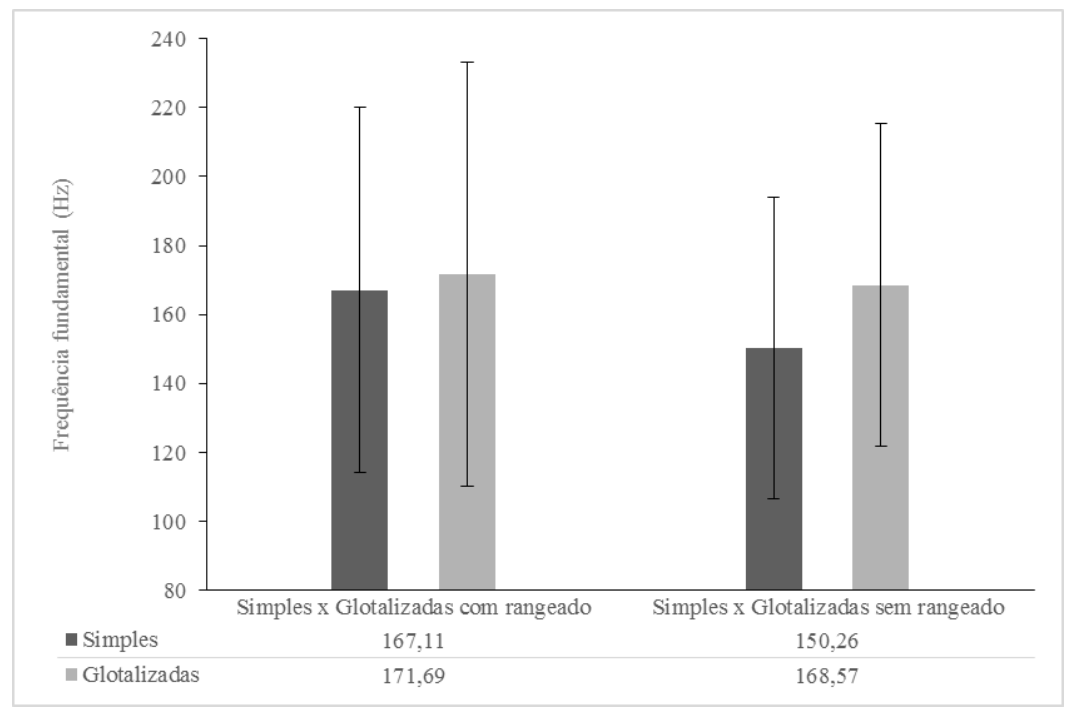

Verifica-se no gráfico da figura 22 que, em ambos os grupos pareados, as consoantes glotalizadas apresentam médias de frequência fundamental superiores às das consoantes simples. Contudo, a diferença nas médias de frequência fundamental das consoantes simples e glotalizadas do grupo de consoantes simples e glotalizadas com rangeado é pequena $(4,58 \mathrm{~Hz})$ e o desvio-padrão das consoantes glotalizadas indicam que há grande sobreposição em intervalos de valores mais prováveis (distância de um desvio-padrão) de frequência fundamental das consoantes simples e glotalizadas do grupo mencionado. No outro grupo pareado, encontra-se uma diferença maior $(18,31 \mathrm{~Hz})$ nas médias de frequência fundamental das consoantes simples e glotalizadas e os desvios-padrão, menos discrepantes, apontam para menor sobreposição de intervalos de valores mais prováveis. Em concordância com a observação dos dados descritivos, vê-se, na tabela 7 , que não há diferença significativa nas médias de frequência fundamental das consoantes simples e glotalizadas do grupo de consoantes simples e glotalizadas com rangeado $(\mathrm{t}$ $=-0,91, \mathrm{p}=0,364)$. Por sua vez, as médias de frequência fundamental das consoantes simples e glotalizadas do grupo de consoantes simples e glotalizadas sem rangeado apresentam diferença significativa $(\mathrm{t}=-6,55, \mathrm{p}<0,001)$ e um tamanho de efeito $d$ de Cohen pequeno $(-0,4)$.

Em ambos os grupos pareados, as consoantes glotalizadas apresentam médias menores de periodicidade do que as consoantes simples equivalentes, conforme mostra a figura 23 . As diferenças são mais notáveis no grupo pareado de consoantes simples e glotalizadas com rangeado $(0,1660$ contra 0,0310$)$, em que até mesmo a média de periodicidade das consoantes simples 
Figura 23 - Comparação das médias de periodicidade (autocorrelação) de consoantes simples e glotalizadas de grupos pareados, com marcação dos desvios-padrão

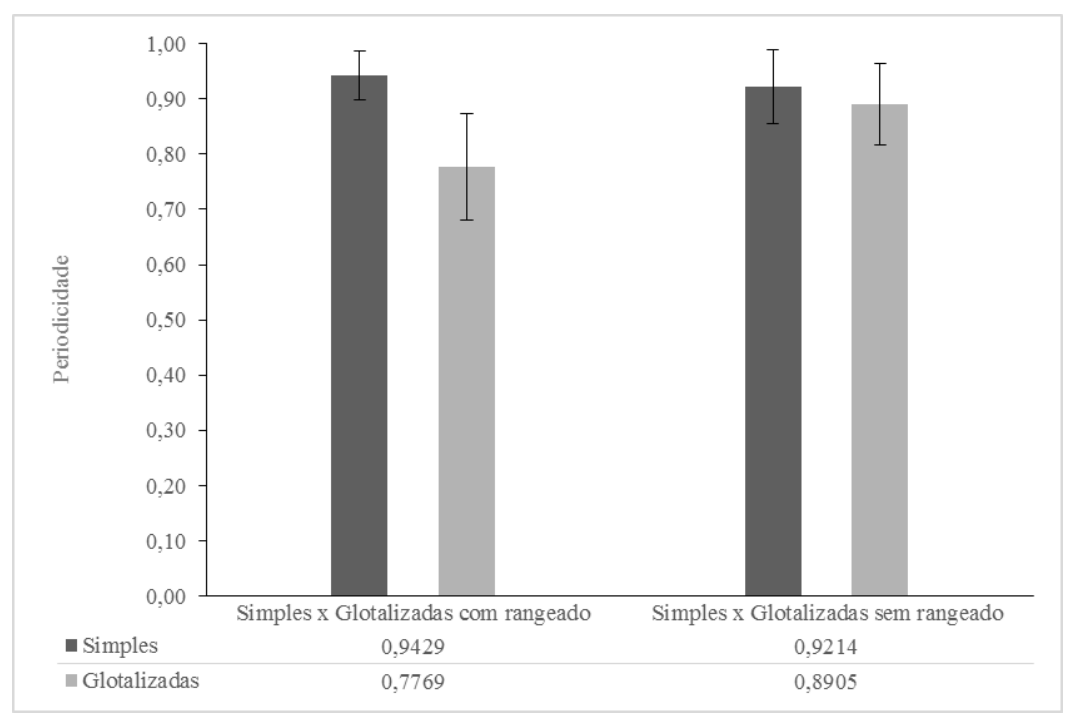

subtraída do seu desvio-padrão $(0,8986)$ é superior à média de periodicidade das consoantes glotalizadas acrescida do seu desvio-padrão $(0,8730)$. As diferenças nas médias de periodicidade são significativas para ambos os grupos, sendo $t=17,39$ e $p<0,001$ para o grupo das consoantes simples e glotalizadas com rangeado e $\mathrm{t}=3,35 \mathrm{e} \mathrm{p}=0,001$ para as consoantes simples e glotalizadas sem rangeado (ver tabela 7$)$. O tamanho do efeito $d$ de Cohen é grande $(2,2)$ para o primeiro grupo e pequeno $(0,44)$ para o segundo grupo (ver tabela 7$)$.

Figura 24 - Comparação das médias de H1-H2 (em dB) de consoantes simples e glotalizadas de grupos pareados, com marcação dos desvios-padrão

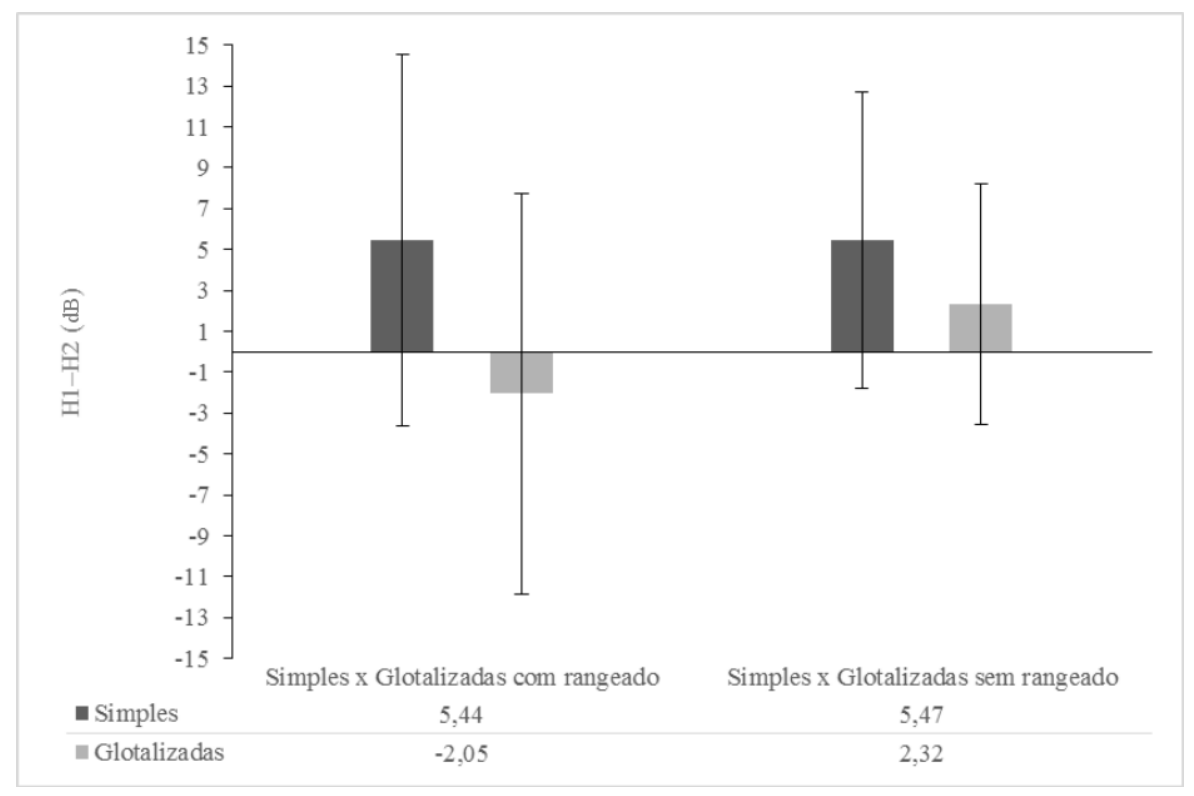

Na figura 24, observa-se que as médias da subtração do primeiro harmônico pelo segundo harmônico $(\mathrm{H} 1-\mathrm{H} 2)$ das consoantes glotalizadas são inferiores às das consoantes simples, considerados os dois grupos pareados. Também se verifica que as diferenças são maiores no grupo pareado das consoantes simples e glotalizadas com rangeado, em que há diferença 
significativa nas médias de $\mathrm{H} 1-\mathrm{H} 2$ das consoantes simples e glotalizadas $(\mathrm{t}=6,85, \mathrm{p}<0,001)$, com tamanho de efeito $d$ de Cohen entre médio e alto $(0,79)$, conforme mostra a tabela 7 . No grupo das consoantes simples e glotalizadas sem rangeado, também há diferença significativa nas médias de $\mathrm{H} 1-\mathrm{H} 2$ das consoantes simples e glotalizadas $(\mathrm{t}=3,97, \mathrm{p}<0,001)$, mas tamanho de efeito $d$ de Cohen entre pequeno e médio $(0,48)$ (ver tabela 7$)$.

Tabela 7 - Diferenças estatísticas, resultados de testes t e tamanhos de efeito $d$ de Cohen para quatro propriedades acústicas de consoantes simples e glotalizadas de grupos pareados

\begin{tabular}{|c|c|c|c|c|c|c|c|c|c|}
\hline & $\mathbf{M}^{a}$ & $\mathrm{SD}^{b}$ & $\mathrm{SE}^{c}$ & Int. Co & f. $95 \%{ }^{d}$ & $\mathrm{t}$ & sig. $(2 \text { caudas })^{e}$ & $\mathrm{~d}^{f}$ & Graus de liberdade ${ }^{g}$ \\
\hline & & & & Inferior & Superior & & & & \\
\hline \multicolumn{10}{|l|}{ Duração } \\
\hline simples - glot. com rang. ${ }^{h}$ & 16,48 & $-6,72$ & $-0,67$ & 17,80 & 15,16 & 3,15 & 0,002 & 0,37 & $99(0)$ \\
\hline simples - glot. sem rang. ${ }^{i}$ & 25,34 & $-9,84$ & $-0,99$ & 27,28 & 23,39 & 4,49 & $<0,001$ & 0,55 & $97(0)$ \\
\hline \multicolumn{10}{|l|}{ Frequência fundamental } \\
\hline simples - glot. com rang. & $-4,58$ & $-8,62$ & $-0,86$ & $-2,89$ & $-6,27$ & $-0,91$ & 0,364 & $-0,08$ & $99(-5)$ \\
\hline simples - glot. sem rang. & $-18,31$ & $-3,10$ & $-0,32$ & $-17,68$ & $-18,94$ & $-6,55$ & $<0,001$ & $-0,40$ & $92(-4)$ \\
\hline \multicolumn{10}{|l|}{$\underline{\text { Periodicidade }}$} \\
\hline simples - glot. com rang. & 0,1660 & $-0,0518$ & 0,0052 & 0,1762 & 0,1558 & 17,39 & $<0,001$ & 2,22 & $99(-5)$ \\
\hline simples - glot. sem rang. & 0,0310 & $-0,0064$ & $-0,0007$ & 0,0322 & 0,0297 & 3,35 & 0,001 & 0,44 & $92(-4)$ \\
\hline \multicolumn{10}{|l|}{$\underline{\mathrm{H} 1-\mathrm{H} 2}$} \\
\hline simples - glot. com rang. & 7,49 & $-0,74$ & $-0,07$ & 7,64 & 7,35 & 6,85 & $<0,001$ & 0,79 & $99(-19)$ \\
\hline simples - glot. sem rang. & 3,14 & 1,39 & 0,14 & 2,86 & 3,43 & 3,97 & $<0,001$ & 0,48 & $92(-4)$ \\
\hline
\end{tabular}

Notas:

\begin{abstract}
${ }^{a}$ Média ${ }^{b}$ Desvio-padrão ${ }^{c}$ Erro padrão ${ }^{d}$ Intervalo de confiança de $95 \%$ para a média ${ }^{e}$ Significância (duas caudas) ${ }^{f}$ Tamanho de efeito $d$ de Cohen ${ }^{g}$ Valores entre parênteses: diferenças entre o número de casos não identificados das consoantes simples e glotalizadas ${ }^{h}$ Diferenças entre consoantes simples e consoantes glotalizadas com rangeado ${ }^{i}$ Diferenças entre consoantes simples e consoantes glotalizadas sem rangeado
\end{abstract}

Em todos os casos, as médias das medidas acústicas das consoantes glotalizadas de ambos os grupos pareados apresentam as mesmas tendências em relação às médias das medidas acústicas das consoantes simples dos seus grupos respectivos. Levando em conta apenas os dados descritivos, as consoantes glotalizadas dos dois grupos são mais curtas, têm frequência fundamental maior, têm níveis de periodicidade menores e apresentam valores de $\mathrm{H} 1-\mathrm{H} 2$ mais baixos do que as suas equivalentes simples. Cabe lembrar, contudo, que os testes estatísticos demonstram que os níveis de significância das diferenças nas médias divergem. O caso mais importante a ser notado é o da frequência fundamental. Embora as médias de frequência fundamental sejam relativamente mais altas para as consoantes glotalizadas de ambos os grupos, somente as diferenças nas médias de frequência fundamental das consoantes simples e glotalizadas do grupo de consoantes simples e glotalizadas sem rangeado são significativas. Além das divergências nos níveis de significância das diferenças nas médias, há também tamanhos de efeito $d$ de Cohen distintos para cada medida acústica e para cada grupo pareado. Os tamanhos de efeito $d d e$ Cohen grandes limitam-se às diferenças nas médias de periodicidade $(2,22)$ e H1-H2 $(0,79)$ das consoantes simples e glotalizadas do grupo de consoantes simples e glotalizadas com rangeado. Foram calculados tamanhos de efeito médios para as diferenças nas médias de duração $(0,55)$ e 
de H1-H2 $(0,48)$ das consoantes simples e glotalizadas do grupo de consoantes simples e glotalizadas sem rangeado. As diferenças nas médias de frequência fundamental e periodicidade das consoantes simples e glotalizadas do grupo de consoantes simples e glotalizadas sem rangeado apresentaram tamanho de efeito pequeno, respectivamente, $-0,40$ e 0,44. Por fim, também foi obtido tamanho de efeito pequeno para as diferenças nas médias de duração das consoantes simples e glotalizadas do grupo pareado de consoantes simples e glotalizadas com rangeado $(0,37)$.

\subsection{Discussão}

Os resultados demonstram que as consoantes glotalizadas distinguem-se das consoantes simples por meio de várias propriedades acústicas. Em todas as quatro propriedades verificadas duração, frequência fundamental, periodicidade e H1-H2 -, as diferenças entre as consoantes glotalizadas e as consoantes simples são estatisticamente significativas, com tamanhos de efeito $d$ de Cohen que variam de pequeno para grande. Como dito na seção 4.3, as tendências para as consoantes de ambos os grupos de consoantes glotalizadas - com rangeado e sem rangeado são as mesmas, mas as características mais salientes das consoantes com e sem rangeado são diferentes; as diferenças de média e os tamanhos de efeito $d$ de Cohen são notavelmente distintos.

Os dois grupos de consoantes glotalizadas não são homogêneos, dado que é possível encontrar mais de uma forma fonética em cada grupo. Apesar disso, as formas mais comuns dentro de cada grupo podem ser descritas como fonação rangeada (consoantes glotalizadas com rangeado) e voz áspera (consoantes glotalizadas sem rangeado). Na literatura sobre o tema, existe uma quantidade considerável de análises acústicas de segmentos produzidos com fonação rangeada, mas o mesmo não pode ser dito a respeito de segmentos com voz áspera.

A descrição da produção da voz áspera oferecida por Edmondson e Esling (2006) (ver capítulo 2) e até mesmo a impressão auditória provocada por esse tipo de fonação permitem supor algumas de suas características acústicas. A característica mais previsível das consoantes com voz áspera é o alto nível de frequência fundamental, percebido pelo aumento da altura (pitch), em razão do alongamento das pregas vocais (EDMONDSON; ESLING, 2006, p. 169) durante esse tipo de fonação. Os resultados, conforme visto, confirmam que as consoantes glotalizadas com voz áspera, que se incluem no grupo das consoantes glotalizadas sem rangeado, têm frequência fundamental superior à das consoantes simples. Devido à forte tensão longitudinal, nos termos Laver (1980), não se espera que as pregas vocais apresentem oscilações muito irregulares, embora a constrição mais intensa de várias estruturas laríngeas possa produzir uma qualidade sonora particular, com maior irregularidade nos ciclos glotais. A tabela 7 mostra que há diferenças significativas nas médias de periodicidade das consoantes glotalizadas sem rangeado e simples com tamanho de efeito $d$ de Cohen pequeno. A força exercida pelas pregas ventriculares sobre as pregas vocais (ver capítulo 2) deve, em tese, levar a um nível de constrição maior destas e a uma fase fechada do ciclo glotal mais extensa. Considerando que H1-H2 possui 
correlação com a fase aberta do ciclo glotal (NÍ; GOBL, 1999, p. 440), parece razoável supor que as consoantes glotalizadas com voz áspera apresentem H1-H2 menor, o que também se observa na comparação entre as consoantes glotalizadas sem rangeado e as consoantes simples.

Gordon e Ladefoged (2001) coligem informações sobre as características acústicas dos segmentos com fonação rangeada de diferentes línguas. Em síntese, os autores relatam valores de frequência fundamental, intensidade acústica e H1-H2 menores (GORDON; LADEFOGED, 2001, p. 396-401). A variação na duração dos ciclos glotais, mencionada como jitter, é, segundo Gordon e Ladefoged (2001), uma característica frequentemente associada à fonação rangeada. Os resultados deste estudo são, em grande medida, compatíveis, havendo diferença apenas no que tange à frequência fundamental. Apesar de não existir diferença estatística de frequência fundamental entre consoantes simples e glotalizadas com rangeado, o gráfico da figura 22 mostra que a média de frequência fundamental é ligeiramente maior entre as consoantes glotalizadas ${ }^{5}$.

As consoantes glotalizadas poderiam ser compreendidas como segmentos que têm uma articulação laríngea adicional, como dito por Martins (2004). A ideia de que há uma "articulação adicional" nas consoantes glotalizadas poderia levar à suposição de que elas precisam de um intervalo de tempo maior para serem produzidas. Na verdade, todas as consoantes soantes têm articulação laríngea, ou seja, ajustes mecânicos (e aerodinâmicos) de estruturas da laringe que produzem som, porque elas são vozeadas. A diferença entre as consoantes simples e glotalizadas se encontra em quais ajustes são feitos, que resultam em modos de fonação e, portanto, em qualidades sonoras distintas. Portanto, não há uma "articulação adicional" nas consoantes glotalizadas. Ao contrário do que se poderia supor, as consoantes glotalizadas são, em média, mais curtas do que as consoantes simples, considerado cada grupo pareado separadamente. $\mathrm{O}$ resultado talvez possa ser explicado pelo fato de que as consoantes glotalizadas têm, em geral, o início, quando em início de palavra, ou o final, quando em fim de palavra, mais abruptos, o que provavelmente se relaciona com a constrição de estruturas laríngeas iniciada antes ou mantida após o final da produção das consoantes.

Dentre as três abordagens dos modos de fonação e articulações laríngeas discutidas no capítulo 2, a abordagem de Peter Ladefoged é a mais econômica e simples. Talvez um estudo articulatório das consoantes glotalizadas com fonação rangeada e voz áspera possa mostrar diferenças significativas no grau de fechamento da glote, mas as diferenças mais notáveis entre os dois tipos de fonação parecem estar relacionadas com outros atributos. A proposta teórica de Peter Ladefoged permite distinguir as consoantes simples e glotalizadas da língua Dâw, mas parece ser insuficiente para diferenciar as duas formas mais comuns da glotalização. A proposta de John Laver também se limita ao nível da glote, porém descreve-o de maneira multidimensional. Uma das diferenças mais importantes das consoantes glotalizadas com fonação rangeada e voz áspera diz respeito à tensão longitudinal, desconsiderada no contínuo de Peter Ladefoged, que permite explicar as diferenças nos níveis de frequência fundamental e periodicidade. O sistema

5 No estudo do capítulo 5, a frequência fundamental é avaliada em diferentes partes das consoantes e das vogais adjacentes. Os resultados ajudam a explicar o motivo de as consoantes glotalizadas com fonação rangeada terem médias de frequência fundamental mais altas. 
de mecanismos ou válvulas da laringe proposto por John Esling oferece meios mais detalhados de distinguir as soantes simples e glotalizadas com fonação rangeada, voz áspera e outras formas fonéticas, fornecendo informações articulatórias que podem ajudar a explicar as diferenças acústicas observadas nos diferentes tipos de fonação e formas das consoantes glotalizadas. Por este motivo, a abordagem de John Esling é, dentre as três, a mais adequada para o estudo da glotalização na língua Dâw. 


\section{5}

\section{As propriedades acústicas da glotalização no domínio do tempo}

Quando se avaliam qualitativamente as consoantes glotalizadas da língua Dâw, observa-se que a glotalização não se apresenta de maneira homogênea e, em geral, não compreende toda a extensão das consoantes. A palavra $/ \mathrm{w}^{2} \check{\gamma}^{\mathrm{j}} \mathrm{T} /$ representada na figura 25 contém uma consoante glotalizada em ataque e outra em coda silábica $-/ \mathrm{w}^{2} /$ e $/ \mathrm{j}^{2} /-$, que possuem tipos de fonação distintos: voz áspera e fonação rangeada, respectivamente. Na consoante $/ \mathrm{w}^{2} /$, o aumento de frequência fundamental (B) é muito mais notável nas partes inicial e intermediária do segmento, demarcadas por retângulos com cantos arredondados na figura 25. Nota-se também intensidade acústica consideravelmente baixa nessa região. Por sua vez, na consoante $/ \mathrm{j} \%$, o nível de periodicidade se apresenta muito baixo nas partes intermediária e final do segmento (áreas demarcadas por retângulos na figura 25), havendo, inclusive, interrupção no sinal acústico por aproximadamente $34 \mathrm{~ms}$. A vogal / $\check{\gamma} /$ não aparenta ter nenhuma das propriedades mencionadas, que, como dito no capítulo 4 , são as principais características da voz áspera e da fonação rangeada.

Figura 25 - Oscilograma (A) e curva de frequência fundamental (B) da palavra $/ w^{2} \check{\gamma} j^{2} /$ pronunciada por VT

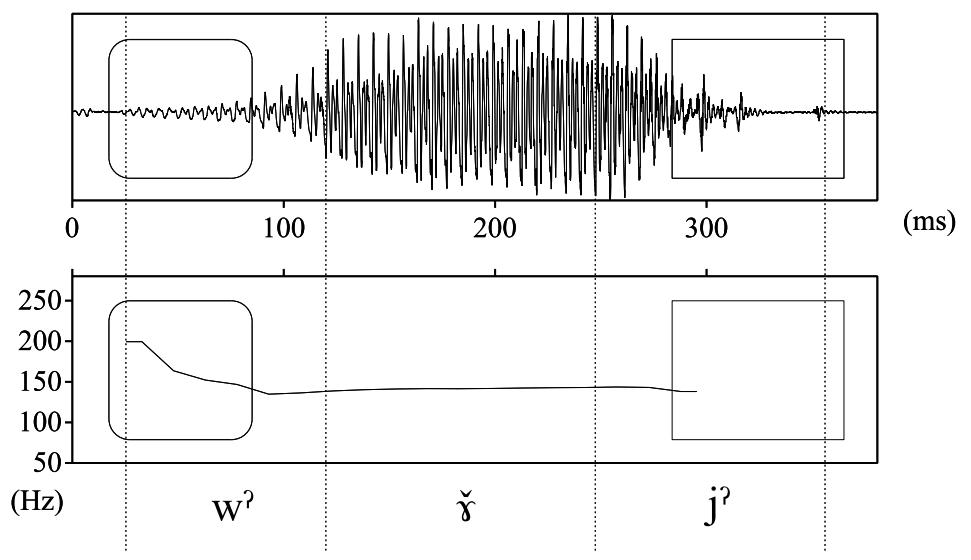

(A)

(B)

Os padrões descritos no parágrafo anterior repetem-se em praticamente todas as palavras da língua Dâw que possuem consoantes glotalizadas, com algumas variações na extensão da região 
que concentra mudanças mais intensas no tipo de fonação. As consoantes em ataque e em coda silábica apresentam padrões espelhados: nas consoantes em ataque silábico, a glotalização é mais intensa no início e, nas consoantes em coda silábica, a glotalização é mais intensa em sua parte final. Em ambos os casos, a glotalização se apresenta sob forma mais atenuada à medida que as consoantes se aproximam das vogais adjacentes.

A fim de verificar se a glotalização se restringe (nas suas formas mais intensas, pelo menos) às partes das consoantes mais distantes das vogais adjacentes, de observar como é a evolução das alterações provocadas pela glotalização em cada uma das propriedades acústicas dos segmentos e em que medida são afetadas as vogais adjacentes, foi conduzido um estudo semelhante ao descrito no capítulo 4, porém, neste caso, também foram contempladas as vogais adjacentes às consoantes em comparação e todos os segmentos foram divididos em três partes de mesma duração. A única medida presente no estudo do capítulo 4 que não se repetiu neste estudo foi a duração, porque a divisão dos segmentos em três partes iguais resulta, obviamente, em médias de duração iguais para cada parte. Para a aferição das outras propriedades acústicas - frequência fundamental, periodicidade e $\mathrm{H} 1-\mathrm{H} 2$-, que também estão presentes neste estudo, empregou-se a mesma metodologia descrita na seção 4.2. Para as consoantes, manteve-se o corpus apresentado na seção 4.1. Para as vogais, por sua vez, admitiu-se a exclusão dos pares de palavras com diferenças nas marcações tonais: os pares 2, 7 e 10 da tabela 6. Procedeu-se à exclusão dessas palavras para evitar a interferência dos tons nos resultados das vogais, especialmente nos valores de frequência fundamental e H1-H2.

Na seção 5.1, apresentam-se os critérios para a divisão das partes dos segmentos e a sua codificação. As informações sobre os aspectos metodológicos deste estudo que coincidem com os do estudo discutido no capítulo anterior podem ser conferidas na seção 4.2. Como não há adições ou mudanças no corpus, a descrição que consta na seção 4.1 também se aplica a este estudo e não foi repetida neste capítulo. Os resultados são tratados na seção 5.2 e a sua discussão, que se relaciona com outros capítulos desse trabalho, é feita na seção 5.3.

\subsection{Metodologia}

Empregaram-se os mesmos procedimentos e critérios do estudo descrito no capítulo 4 para a formação dos grupos pareados, a aferição das medidas acústicas e o tratamento estatístico dos dados. As consoantes e as vogais foram divididas em três partes de mesma duração, como ilustra o esquema da figura 26. Optou-se por dividir os segmentos em três partes porque cada parte representa, de maneira aproximada, um estágio do segmento - o início (onset), o meio ou o estágio alvo (target) e o fim (offset) - e porque o número de partes permite, na maioria dos casos, que os espectros FFT tenham resolução adequada (largura de banda menor do que $43 \mathrm{~Hz}$ ). A divisão dos segmentos em três partes nem sempre resulta na separação de estágios, mesmo que considerados de maneira aproximada. As aproximantes [j] e [w], por exemplo, não atingem o alvo articulatório em sua parte intermediária, porque elas se caracterizam pela mudança na 
frequência dos formantes ao longo de praticamente toda a sua extensão. Apesar disso, como qualquer segmento, as aproximantes mencionadas podem ser divididas em intervalos que estão mais ou menos próximos do contato com o segmento contíguo. Nos casos em que as partes tinham duração inferior a $30 \mathrm{~ms}$, adotou-se a sobreposição mínima das partes (ver figura 27), o que significa que as partes sucessivas $x_{i}$ e $x_{i+1}$ compartilham um intervalo equivalente a $\frac{[(30 \times 3)-d]}{2}$, em que $d$ é a duração total do segmento. Desconsideraram-se os segmentos com duração total menor do que $60 \mathrm{~ms}$, a fim de evitar sobreposição das partes inicial e final.

Figura 26 - Demarcação das partes de [1] e [a] em um oscilograma da palavra $/ \mathrm{l}^{\mathrm{T}} \mathrm{ax} /$ pronunciada por DO

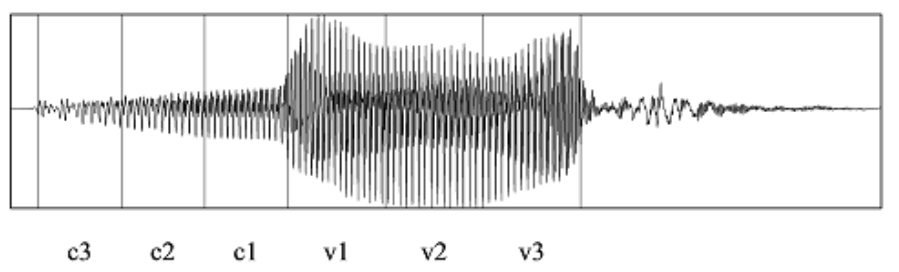

Legenda:

cn - parte n (1 a 3) da consoante, vn - parte n (1 a 3) da vogal

Figura 27 - Demarcação das partes de [o] e [n²] em um oscilograma da palavra $/$ lon?/ pronunciada por MT

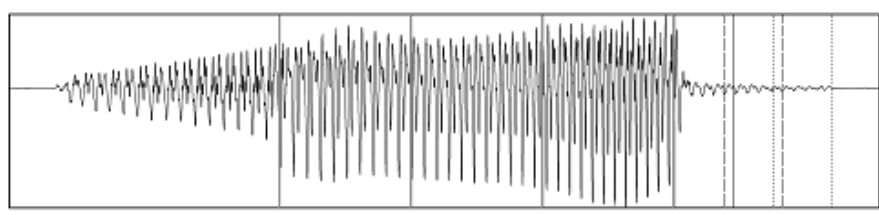

v3

v2

v1

c1 $\quad$ c2 $\quad$ c3

Legenda:

cn - parte n (1 a 3) da consoante, vn - parte n (1 a 3) da vogal

linha sólida - limites de v1, v2, v3 e c1

linha tracejada - limites de c2

linha pontilhada - limites de c3

Os espaços entre as linhas tracejada e sólida, pontilhada e tracejada equivalem à sobreposição de $\mathrm{c} 1 \mathrm{e} \mathrm{c} 2, \mathrm{c} 2 \mathrm{e} \mathrm{c} 3$, na ordem respectiva.

A codificação das partes baseou-se na sua posição relativa ao contato com o segmento adjacente. Quanto mais distante do contato com o segmento vizinho, maior o número. Como todas as palavras do corpus são constituídas apenas de uma sílaba CV ou CVC (ver tabela 6), exceto $/ \mathrm{oj}^{\mathrm{T}} \mathrm{ah} /{ }^{1}$, as partes das consoantes em ataque e coda silábicas têm codificações espelhadas: o intervalo 3 é a parte inicial das consoantes em ataque e a parte final das consoantes em coda, o intervalo 2 é a parte intermediária das consoantes que se encontram em ambas as posições

1 Neste caso, considerou-se /a/ como a vogal adjacente relevante para estabelecer a codificação de /j/, a fim de manter a possibilidade de comparação com /jah/. 
e o intervalo 1 é a parte final das consoantes em ataque e a parte inicial da consoantes em coda. O mesmo método foi aplicado às vogais (ver figuras 26 e 27). Note-se, entretanto, que considerou-se apenas o contato com consoantes glotalizadas ou a sua correspondente simples no mesmo par para estabelecer os códigos dos intervalos das vogais. É possível observar nas figuras 26 e 27 que as partes v1 são as mais próximas de c1 e que as consoantes [x] da palavra $/ l^{?} \mathrm{ax} /$ e [1] da palavra /lon?/ não interferem na numeração das partes das vogais.

\subsection{Resultados}

Observa-se na figura 28 que a parte mais distante da vogal adjacente (c3) e a parte intermediária (c2) das consoantes glotalizadas com rangeado têm médias de frequência fundamental inferiores (156, 40 Hz em c3 e 155, 94 Hz em c2) às das respectivas partes das consoantes simples do mesmo grupo pareado (163, $55 \mathrm{~Hz}$ em c3 e 165, $71 \mathrm{~Hz}$ em c2). No entanto, a relação invertese para a parte mais próxima da vogal adjacente (c1), em que as consoantes glotalizadas com rangeado têm média de frequência fundamental maior $(178,38 \mathrm{~Hz})$ do que as consoantes simples $(171,85 \mathrm{~Hz})$. A figura 29 mostra que, em todas as partes, as médias de frequência fundamental são maiores nas consoantes glotalizadas sem rangeado (166, $99 \mathrm{~Hz}$ em c3, 167, 52 HZ em c2 e $168,80 \mathrm{~Hz}$ em c1) do que nas consoantes simples (145, $03 \mathrm{~Hz}$ em c3, 149, $89 \mathrm{~Hz}$ em c2 e 155, 82 $\mathrm{Hz}$ em c1). Porém, nota-se que as diferenças entre as médias de frequência fundamental das partes das consoantes glotalizadas sem rangeado e das partes das consoantes simples diminuem à medida que se aproximam as vogais adjacentes, ou seja, as diferenças diminuem de c3 para c1, tendo c2 uma diferença intermediária. Na tabela 8 , verifica-se que as diferenças nas médias de frequência fundamental das partes das consoantes glotalizadas com rangeado e das consoantes simples não são significativas $(\mathrm{t}=1,77$ e $\mathrm{p}=0,081$ em $\mathrm{c} 3, \mathrm{t}=1,35$ e $\mathrm{p}=0,180$ em c2, $\mathrm{t}=$ $-2,42$ e $\mathrm{p}=0,017$ em $\mathrm{c} 1)$. Por outro lado, a tabela mencionada mostra que as diferenças nas médias de frequência fundamental de todas as partes das consoantes glotalizadas sem rangeado e das consoantes simples são significativas $(\mathrm{t}=-5,85$ e $\mathrm{p}<0,001$ em $\mathrm{c} 3, \mathrm{t}=-6,01$ e $\mathrm{p}<0,001$ em $\mathrm{c} 2, \mathrm{t}=-5,87 \mathrm{e} \mathrm{p}<0,001 \mathrm{em} \mathrm{c}$ ), com tamanhos de efeito $d$ de Cohen de pequeno para médio ( $-0,45$ em c3, -0, 39 em c2 e $-0,29$ em c1).

Em todas as suas partes, as vogais adjacentes às consoantes glotalizadas com rangeado têm médias de frequência fundamental maiores $(186,31 \mathrm{~Hz}$ em v1, 177, $93 \mathrm{~Hz}$ em v2 e 167, $88 \mathrm{~Hz}$ em v3) do que as das vogais adjacentes às consoantes simples do mesmo grupo pareado (176,55 $\mathrm{Hz}$ em v1, 174, $18 \mathrm{~Hz}$ em v2 e 166, $56 \mathrm{~Hz}$ em v3), conforme se observa na figura 28. Note-se também que há diminuição nas diferenças de v1 (parte das vogais mais próxima às consoantes em comparação) a v3 (parte das vogais mais distante das consoantes em comparação). Ao comparar, na figura 29, as médias de frequência fundamental das partes das vogais adjacentes às consoantes glotalizadas sem rangeado (179, $45 \mathrm{~Hz}$ em v1, 174, $40 \mathrm{~Hz}$ em v2 e 161, $36 \mathrm{~Hz}$ em v3) com as das partes das vogais adjacentes às consoantes simples do mesmo grupo pareado (168, 38 Hz em v1, 167, 44 Hz em v2 e 159, 37 Hz em v3), encontra-se um padrão muito semelhante, com 
Figura 28 - Médias de frequência fundamental de três partes de mesma duração de consoantes simples, de consoantes glotalizadas com rangeado e das vogais adjacentes às consoantes de ambos os tipos

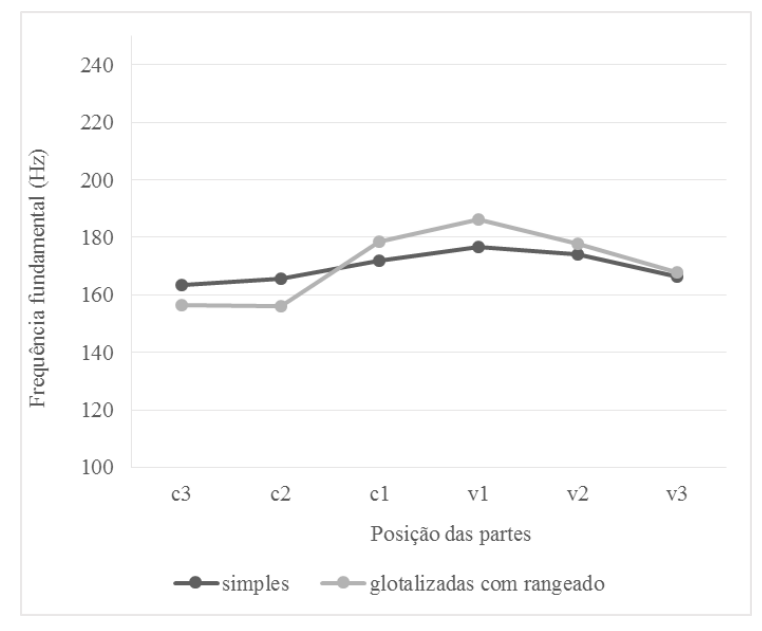

Figura 29 - Médias de frequência fundamental de três partes de mesma duração de consoantes simples, de consoantes glotalizadas sem rangeado e das vogais adjacentes às consoantes de ambos os tipos

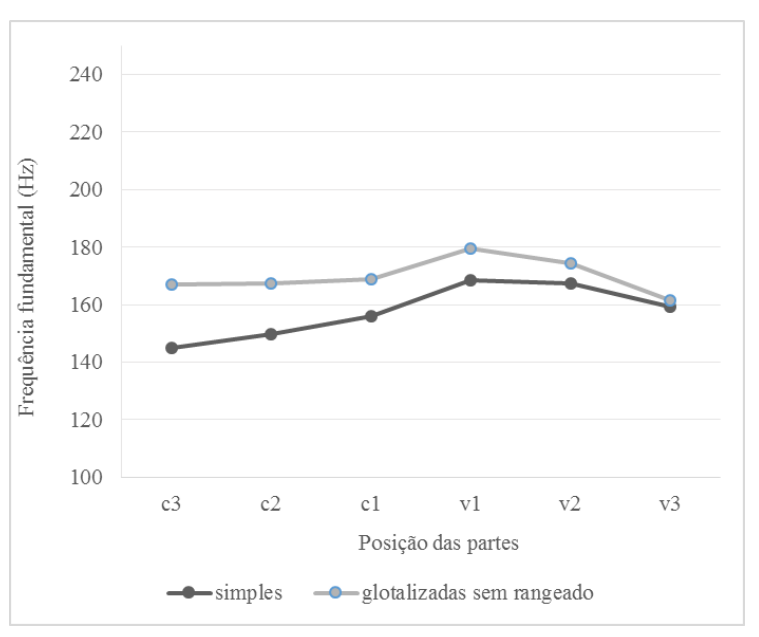

Legenda:

c1 - consoante na posição 1 (mais próxima à vogal adjacente)

c2 - consoante na posição 2 (intermediária)

c3 - consoante na posição 3 (mais distante da vogal adjacente)

v1 - vogal na posição 1 (mais próxima à consoante relevante)

v2 - vogal na posição 2 (intermediária)

v3 - vogal na posição 3 (mais distante da consoante relevante)

divergências apenas nos valores exatos das diferenças. A tabela 9 mostra que apenas em v1 a diferença nas médias de frequência fundamental das vogais adjacentes às consoantes glotalizadas com rangeado e das vogais adjacentes às consoantes simples é significativa $(\mathrm{t}=-6,15 \mathrm{e} p$ $<0,001)$, com efeito $d$ de Cohen pequeno $(-0,16)$. Na mesma tabela, verifica-se que são significativas as diferenças nas médias de frequência fundamental das partes v1 $(\mathrm{t}=-7,39 \mathrm{e} \mathrm{p}$ $<0,001)$ e v2 ( $\mathrm{t}=-4,44 \mathrm{e} \mathrm{p}<0,001)$ das vogais adjacentes às consoantes glotalizadas sem rangeado e das vogais adjacentes às consoantes simples, com tamanhos de efeito $d$ de Cohen também pequenos $(-0,24 \mathrm{em}$ v1 e $-0,15 \mathrm{em}$ v2).

A figura 30 mostra que as três partes das consoantes glotalizadas com rangeado têm níveis de periodicidade médios claramente inferiores (0,68 em c3, 0,74 em c2 e 0, 85 em c1) aos das três partes das consoantes simples correspondentes (0,91 em c3, 0,98 em c2 e 0,94 em c1). Cabe mencionar que as diferenças nos níveis de periodicidade médios são muito maiores nas partes c3 e c2 (0,23 e 0,24, respectivamente), mais distantes das vogais adjacentes, do que na parte c1 $(0,09)$, mais próxima às vogais adjacentes. Como se vê na figura 31 , as diferenças nos níveis de periodicidade médios das partes das consoantes glotalizadas sem rangeado e das consoantes simples são muito menores ( 0,04 em c3, 0, 03 em c2 e 0, 02 em c1). A despeito disso, as partes das consoantes glotalizadas apresentam novamente valores médios inferiores $(0,85 \mathrm{em}$ c3, 0, 93 em c2 e 0, 90 em c1) aos das consoantes simples (0, 89 em c3, 0, 96 em c2 e 0, 92 em 
c1). Em todas partes, conforme apresenta a tabela 8, as diferenças nas médias de periodicidade das consoantes glotalizadas com rangeado e das consoantes simples são significativas $(t=13,30$ e p $<0,001$ em c3, t $=18,89$ e $\mathrm{p}<0,001$ em c2, t $=7,72$ e p $<0,001$ em c1), com tamanhos de efeito $d$ de Cohen grandes (2,37 em c3, 2, 95 em c2 e 0,91 em c3). Ainda na tabela 8, verifica-se que somente as diferenças nos níveis de periodicidade médios das partes c3 e c2 das consoantes glotalizadas sem rangeado e das consoantes simples são significativas $(\mathrm{t}=3,39$ e $\mathrm{p}<0,001 \mathrm{em}$ $\mathrm{c} 3, \mathrm{t}=3,73$ e $\mathrm{p}<0,001$ em $\mathrm{c} 2)$, sendo os tamanhos de efeito $d$ de Cohen pequeno em $\mathrm{c} 3(0,44)$ e médio em c2 $(0,55)$.

Figura 30 - Médias de periodicidade de três partes de mesma duração de consoantes simples, de consoantes glotalizadas com rangeado e das vogais adjacentes às consoantes de ambos os tipos

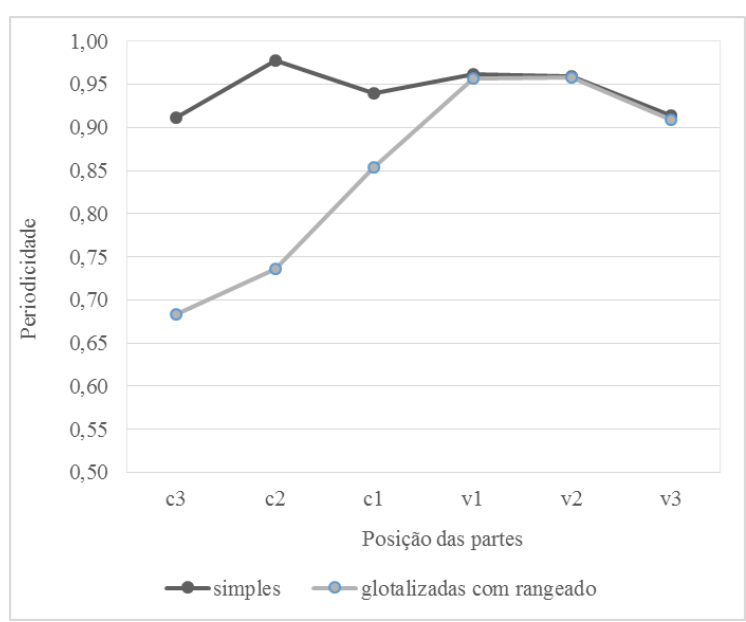

Figura 31 - Médias de periodicidade de três partes de mesma duração de consoantes simples, de consoantes glotalizadas sem rangeado e das vogais adjacentes às consoantes de ambos os tipos

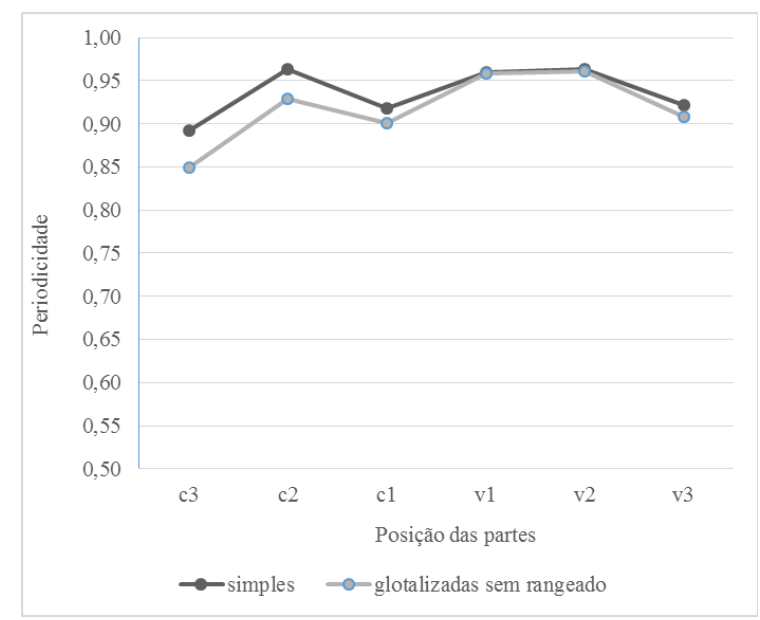

Legenda:

c1 - consoante na posição 1 (mais próxima à vogal adjacente)

c2 - consoante na posição 2 (intermediária)

c3 - consoante na posição 3 (mais distante da vogal adjacente)

v1 - vogal na posição 1 (mais próxima à consoante relevante)

v2 - vogal na posição 2 (intermediária)

v3 - vogal na posição 3 (mais distante da consoante relevante)

As figuras 30 e 31 mostram diferenças pequenas, em ambos os grupos de segmentos pareados, nas médias de periodicidade das partes das vogais adjacentes às consoantes glotalizadas e das vogais adjacentes às consoantes simples. Em todos os casos, as médias de periodicidade das partes das vogais adjacentes às consoantes glotalizadas com rangeado são ligeiramente inferiores

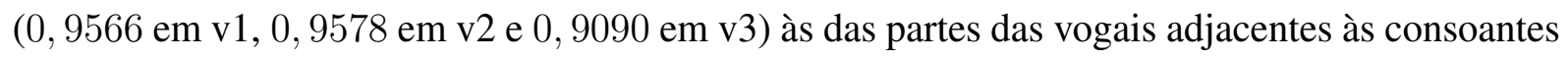
simples correspondentes (0,9623 em v1, 0, 9590 em v2 e 0,9141 em v3). O mesmo se repete para as diferenças nas médias de periodicidade das partes das vogais adjacentes às consoantes glotalizadas sem rangeado ( $0,9585 \mathrm{em}$ v1, 0, $9606 \mathrm{em}$ v2 e 0, $9076 \mathrm{em}$ v3) e das vogais adjacentes às consoantes simples (0, $9599 \mathrm{em}$ v1, 0,9635 em v2 e 0,9211 em v3), alterando-se, obviamente, apenas os valores. Como esperado, a tabela 9 aponta para inexistência de diferença significativa 
em todos dos casos, ou seja, não há diferença significativa em nenhuma das partes das vogais de nenhum dos grupos pareados.

Tabela 8 - Diferenças estatísticas, resultados de testes t e tamanhos de efeito $d$ de Cohen para três propriedades acústicas de três partes de mesma duração de consoantes simples e glotalizadas de grupos pareados

\begin{tabular}{|c|c|c|c|c|c|c|c|c|c|}
\hline \multirow{2}{*}{ Frequência fundamental } & $\mathrm{M}^{a}$ & $\mathrm{SD}^{b}$ & $\mathrm{SE}^{c}$ & \multicolumn{2}{|c|}{ Int. Conf. $95 \%^{d}$} & $\mathrm{t}$ & sig. $(2 \text { caudas })^{e}$ & $\mathrm{~d}^{f}$ & Graus de liberdade ${ }^{s}$ \\
\hline & & & & & & & & & \\
\hline \multicolumn{10}{|l|}{ Posição 1} \\
\hline $\begin{array}{l}\text { simples - glot. com rang. }{ }^{h} \\
\text { simples - glot. sem rang. }{ }^{i}\end{array}$ & $\begin{array}{l}-6,53 \\
-12,98\end{array}$ & $\begin{array}{l}-5,49 \\
-0,83\end{array}$ & $\begin{array}{l}-0,55 \\
-0,09\end{array}$ & $\begin{array}{l}-5,46 \\
-12,81\end{array}$ & $\begin{array}{c}-7,61 \\
-13,15\end{array}$ & $\begin{array}{l}-2,42 \\
-5,87\end{array}$ & $\begin{array}{c}0,017 \\
<0,001\end{array}$ & $\begin{array}{l}-0,12 \\
-0,29\end{array}$ & $\begin{array}{l}99(-11) \\
92(-6)\end{array}$ \\
\hline \multicolumn{10}{|l|}{ Posição 2} \\
\hline $\begin{array}{l}\text { simples - glot. com rang. } \\
\text { simples - glot. sem rang. }\end{array}$ & $\begin{array}{c}9,76 \\
-17,63\end{array}$ & $\begin{array}{l}-10,59 \\
-4,09\end{array}$ & $\begin{array}{l}-1,06 \\
-0,42\end{array}$ & $\begin{array}{c}11,84 \\
-16,80\end{array}$ & $\begin{array}{c}7,69 \\
-18,46\end{array}$ & $\begin{array}{l}1,35 \\
-6,01\end{array}$ & $\begin{array}{c}0,180 \\
<0,001\end{array}$ & $\begin{array}{c}0,17 \\
-0,39\end{array}$ & $\begin{array}{l}99(-20) \\
92(-4)\end{array}$ \\
\hline \multicolumn{10}{|l|}{ Posição 3} \\
\hline $\begin{array}{l}\text { simples - glot. com rang. } \\
\text { simples - glot. sem rang. }\end{array}$ & $\begin{array}{c}7,15 \\
-21,95\end{array}$ & $\begin{array}{l}-20,25 \\
-6,52\end{array}$ & $\begin{array}{l}-2,02 \\
-0,68\end{array}$ & $\begin{array}{c}11,12 \\
-20,63\end{array}$ & $\begin{array}{c}3,18 \\
-23,28\end{array}$ & $\begin{array}{c}1,77 \\
-5,85\end{array}$ & $\begin{array}{c}0,081 \\
<0,001\end{array}$ & $\begin{array}{c}0,11 \\
-0,45\end{array}$ & $\begin{array}{c}99(-39) \\
92(-7)\end{array}$ \\
\hline \multicolumn{10}{|l|}{$\underline{\text { Periodicidade }}$} \\
\hline \multicolumn{10}{|l|}{ Posição 1} \\
\hline $\begin{array}{l}\text { simples - glot. com rang. } \\
\text { simples - glot. sem rang. }\end{array}$ & $\begin{array}{l}0,0853 \\
0,0171\end{array}$ & $\begin{array}{l}-0,0499 \\
-0,0060\end{array}$ & $\begin{array}{l}-0,0050 \\
-0,0006\end{array}$ & $\begin{array}{l}0,0951 \\
0,0184\end{array}$ & $\begin{array}{l}0,0756 \\
0,0159\end{array}$ & $\begin{array}{l}7,72 \\
1,84\end{array}$ & $\begin{array}{c}<0,001 \\
0,069\end{array}$ & $\begin{array}{l}0,91 \\
0,20\end{array}$ & $\begin{array}{l}99(-11) \\
92(-6)\end{array}$ \\
\hline \multicolumn{10}{|l|}{ Posição 2} \\
\hline $\begin{array}{l}\text { simples - glot. com rang. } \\
\text { simples - glot. sem rang. }\end{array}$ & $\begin{array}{l}0,2417 \\
0,0341\end{array}$ & $\begin{array}{l}-0,0879 \\
-0,0259\end{array}$ & $\begin{array}{l}-0,0088 \\
-0,0027\end{array}$ & $\begin{array}{l}0,2589 \\
0,0394\end{array}$ & $\begin{array}{l}0,2245 \\
0,0289\end{array}$ & $\begin{array}{c}18,89 \\
3,73\end{array}$ & $\begin{array}{l}<0,001 \\
<0,001\end{array}$ & $\begin{array}{l}2,95 \\
0,55\end{array}$ & $\begin{array}{l}99(-20) \\
92(-4)\end{array}$ \\
\hline \multicolumn{10}{|l|}{ Posição 3} \\
\hline $\begin{array}{l}\text { simples - glot. com rang. } \\
\text { simples - glot. sem rang. }\end{array}$ & $\begin{array}{l}0,2270 \\
0,0430\end{array}$ & $\begin{array}{l}-0,0333 \\
-0,0329\end{array}$ & $\begin{array}{l}-0,0033 \\
-0,0034\end{array}$ & $\begin{array}{l}0,2335 \\
0,0496\end{array}$ & $\begin{array}{l}0,2205 \\
0,0363\end{array}$ & $\begin{array}{c}13,30 \\
3,39\end{array}$ & $\begin{array}{c}<0,001 \\
0,001\end{array}$ & $\begin{array}{l}2,37 \\
0,44\end{array}$ & $\begin{array}{l}99(-39) \\
92(-7)\end{array}$ \\
\hline \multicolumn{10}{|l|}{$\underline{\mathrm{H} 1-\mathrm{H} 2}$} \\
\hline \multicolumn{10}{|l|}{ Posição 1} \\
\hline $\begin{array}{l}\text { simples - glot. com rang. } \\
\text { simples - glot. sem rang. }\end{array}$ & $\begin{array}{l}4,49 \\
2,02\end{array}$ & $\begin{array}{c}0,17 \\
-0,07\end{array}$ & $\begin{array}{c}0,02 \\
-0,01\end{array}$ & $\begin{array}{l}4,46 \\
2,04\end{array}$ & $\begin{array}{l}4,52 \\
2,01\end{array}$ & $\begin{array}{l}5,34 \\
3,01\end{array}$ & $\begin{array}{c}<0,001 \\
0,003\end{array}$ & $\begin{array}{l}0,52 \\
0,33\end{array}$ & $\begin{array}{c}99(-12) \\
92(-4)\end{array}$ \\
\hline \multicolumn{10}{|l|}{ Posição 2} \\
\hline $\begin{array}{l}\text { simples - glot. com rang. } \\
\text { simples - glot. sem rang. }\end{array}$ & $\begin{array}{l}7,86 \\
1,87\end{array}$ & $\begin{array}{c}-1,97 \\
0,94\end{array}$ & $\begin{array}{c}-0,20 \\
0,10\end{array}$ & $\begin{array}{l}8,24 \\
1,67\end{array}$ & $\begin{array}{l}7,47 \\
2,06\end{array}$ & $\begin{array}{l}6,99 \\
2,04\end{array}$ & $\begin{array}{c}<0,001 \\
0,045\end{array}$ & $\begin{array}{l}0,81 \\
0,25\end{array}$ & $\begin{array}{l}99(-24) \\
92(-6)\end{array}$ \\
\hline \multicolumn{10}{|l|}{ Posição 3} \\
\hline $\begin{array}{l}\text { simples - glot. com rang. } \\
\text { simples - glot. sem rang. }\end{array}$ & $\begin{array}{l}7,50 \\
2,08\end{array}$ & $\begin{array}{c}-4,05 \\
0,94\end{array}$ & $\begin{array}{c}-0,40 \\
0,10\end{array}$ & $\begin{array}{l}8,30 \\
1,89\end{array}$ & $\begin{array}{l}6,71 \\
2,27\end{array}$ & $\begin{array}{l}4,52 \\
2,01\end{array}$ & $\begin{array}{c}<0,001 \\
0,049\end{array}$ & $\begin{array}{l}0,67 \\
0,26\end{array}$ & $\begin{array}{l}99(-47) \\
92(-9)\end{array}$ \\
\hline
\end{tabular}

Notas:

${ }^{a}$ Média ${ }^{b}$ Desvio-padrão ${ }^{c}$ Erro padrão ${ }^{d}$ Intervalo de confiança de $95 \%$ para a média ${ }^{e}$ Significância (duas caudas) ${ }^{f}$ Tamanho de efeito $d$ de Cohen ${ }^{g}$ Valores entre parênteses: diferenças entre o número de casos não identificados das consoantes simples e glotalizadas ${ }^{h}$ Diferenças entre consoantes simples e consoantes glotalizadas com rangeado ${ }^{i}$ Diferenças entre consoantes simples e consoantes glotalizadas sem rangeado

Verifica-se na figura 32 que as médias de $\mathrm{H} 1-\mathrm{H} 2$ das partes das consoantes glotalizadas com rangeado ( $-0,87 \mathrm{~dB}$ em c3, $-3,08 \mathrm{~dB}$ em c2 e $-1,25 \mathrm{~dB}$ em c1) são consideravelmente 
menores do que as das partes das consoantes simples correspondentes $(6,63 \mathrm{~dB}$ em c3, 4, $78 \mathrm{~dB}$ em c2 e 3, $24 \mathrm{~dB}$ em c1). Com diferenças menos notáveis (ver figura 33), as médias de $\mathrm{H} 1-\mathrm{H} 2$ das três partes das consoantes glotalizadas sem rangeado $(3,14 \mathrm{~dB}$ em c3, 2, $13 \mathrm{~dB}$ em c2 e $1,32 \mathrm{~dB}$ em c1) também são inferiores às das três partes das consoantes simples $(5,22 \mathrm{~dB}$ em c3, 4, $00 \mathrm{~dB}$ em c2 e 3, $34 \mathrm{~dB}$ em c1). Todas as partes apresentam diferenças significativas nas médias de $\mathrm{H} 1-\mathrm{H} 2$ (ver tabela 8 ) no grupo pareado de consoantes glotalizadas com rangeado e de consoantes simples $(\mathrm{t}=4,52$ e $\mathrm{p}<0,001$ em $\mathrm{c} 3, \mathrm{t}=6,99$ e $\mathrm{p}<0,001$ em $\mathrm{c} 2, \mathrm{t}=5,34$ e $\mathrm{p}$ $<0,001 \mathrm{em} \mathrm{c1)}$, com tamanhos de efeito $d$ de Cohen entre médio e grande $(0,67$ em c3, 0, 81 em c2 e 0,52 em c1). Por outro lado, apenas a parte c1 apresenta diferença significativa nas médias de $\mathrm{H} 1-\mathrm{H} 2$ no grupo de consoantes glotalizadas sem rangeado e de consoante simples ( $\mathrm{t}$ $=3,01$ e $\mathrm{p}<0,003)$, sendo pequeno o tamanho de efeito $d$ de Cohen $(0,33)$.

Figura 32 - Médias de H1-H2 de três partes de mesma duração de consoantes simples, de consoantes glotalizadas com rangeado e das vogais adjacentes às consoantes de ambos os tipos
Figura 33 - Médias de H1-H2 três partes de mesma duração de consoantes simples, de consoantes glotalizadas sem rangeado e das vogais adjacentes às consoantes de ambos os tipos
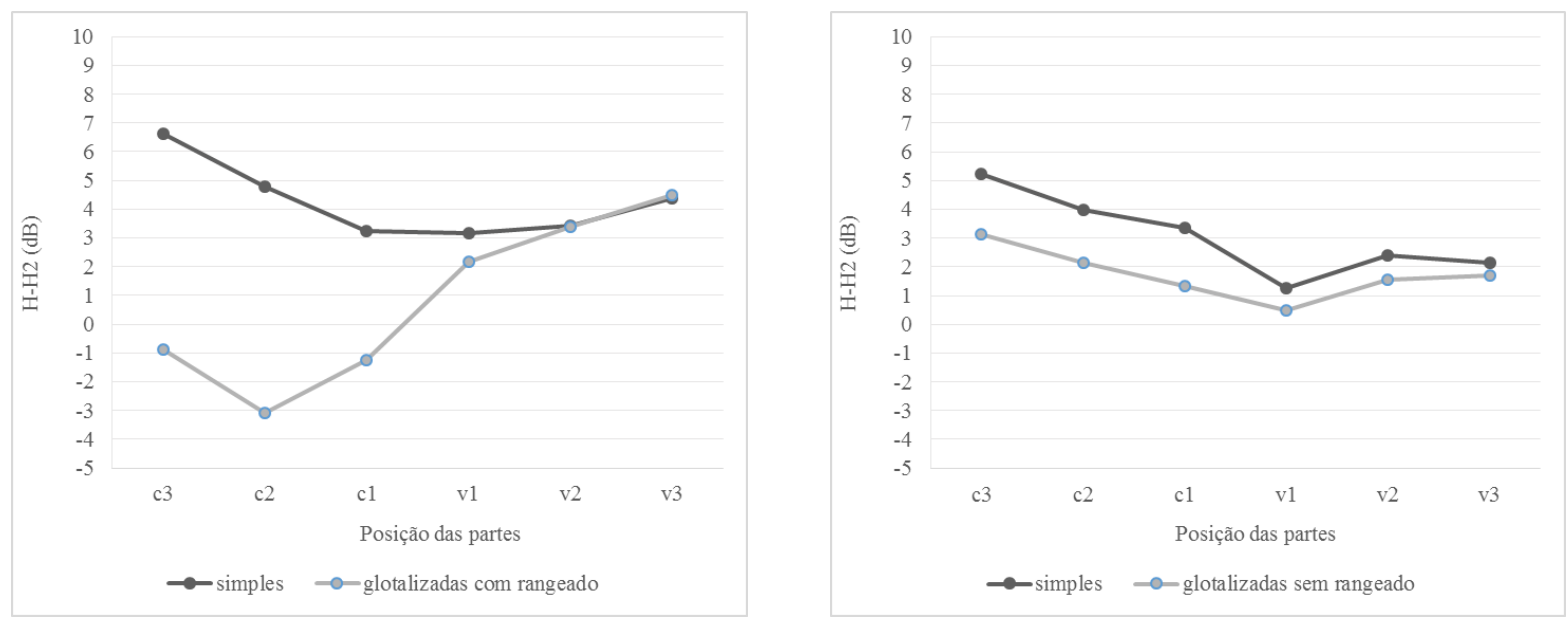

Legenda:

c1 - consoante na posição 1 (mais próxima à vogal adjacente)

c2 - consoante na posição 2 (intermediária)

c3 - consoante na posição 3 (mais distante da vogal adjacente)

v1 - vogal na posição 1 (mais próxima à consoante relevante)

v2 - vogal na posição 2 (intermediária)

v3 - vogal na posição 3 (mais distante da consoante relevante)

A figuras 32 e 33 permitem observar que são muito pequenas as diferenças nas médias de H1-H2 das partes das vogais adjacentes às consoantes glotalizadas e das vogais adjacentes às consoantes simples de ambos os grupos pareados, especialmente no grupo das consoantes glotalizadas com rangeado e das consoantes simples. Neste grupo, as médias de $\mathrm{H} 1-\mathrm{H} 2$ das partes $\mathrm{v} 1 \mathrm{e}$ v2 das vogais adjacentes às consoantes glotalizadas com rangeado $(2,16 \mathrm{~dB}$ em v1 e 3, $40 \mathrm{~dB}$ em v2) são menores do que as médias de $\mathrm{H} 1-\mathrm{H} 2$ das mesmas partes das vogais adjacentes às consoantes simples (3,16 dB em v1 e 3, $42 \mathrm{~dB}$ em v2). Em v3, encontra-se a relação inversa, sendo a média de $\mathrm{H} 1-\mathrm{H} 2$ das consoantes glotalizadas com rangeado equivalente 
a 4, $48 \mathrm{~dB}$ e das consoantes simples igual a 4,38 dB. As médias de $\mathrm{H} 1-\mathrm{H} 2$ das partes das vogais adjacentes às consoantes glotalizadas sem rangeado $(0,49 \mathrm{~dB}$ em v1, 1,54 dB em v2 e 1,70 dB em v3) são sempre inferiores às das partes das vogais adjacentes às consoantes simples do mesmo grupo (1, $26 \mathrm{~dB}$ em v1, 2, $39 \mathrm{~dB}$ em v2 e 2, $14 \mathrm{~dB}$ em v3). Os resultados apresentados na tabela 9 apontam para a inexistência de diferenças significativas nas médias de $\mathrm{H} 1-\mathrm{H} 2$ de todas as partes das vogais adjacentes às consoantes glotalizadas e das vogais adjacentes às consoantes simples pertencentes a ambos os grupos pareados.

Em resumo, as três partes das consoantes glotalizadas com rangeado apresentaram diferenças significativas nas médias de periodicidade e $\mathrm{H} 1-\mathrm{H} 2$ em relação às mesmas partes das consoantes simples correspondentes. Os tamanhos de efeito $d$ de Cohen são grandes para as diferenças nas médias de periodicidade e variam entre médio e grande para as diferenças nas médias de $\mathrm{H} 1-\mathrm{H} 2$. Nenhuma das diferenças verificadas nas partes das consoantes deste grupo pareado estendeu-se às partes das vogais adjacentes. Contudo, houve diferença significativa nas médias de frequência fundamental na posição v1, a mais próxima das consoantes, das vogais adjacentes às consoantes glotalizadas com rangeado e das vogais adjacentes às consoantes simples, com tamanho de efeito d de Cohen pequeno.

Os testes apontaram para diferenças significativas nas médias de frequência fundamental das três partes das consoantes glotalizadas sem rangeado e das consoantes simples do mesmo grupo pareado, com tamanhos de efeito $d$ de Cohen pequenos. As diferenças significativas nas médias de frequência fundamental ultrapassaram as fronteiras das consoantes e atingiram também as partes v1 e v2 (mais próximas das consoantes) das vogais adjacentes, com tamanhos de efeito $d$ de Cohen também pequenos. Observaram-se ainda diferenças significativas nas médias de periodicidade, nas partes c2 e c3, e de $\mathrm{H} 1-\mathrm{H} 2$, na parte $\mathrm{c} 1$, das consoantes glotalizadas sem rangeado e das consoantes simples, com tamanhos de efeito $d$ de Cohen entre pequeno e médio.

\subsection{Discussão}

Como se esperava, os resultados do estudo deste capítulo não divergiram dos resultados obtidos no estudo do capítulo 4, em que se compararam as médias das propriedades acústicas considerando toda a extensão das consoantes, em vez de três partes de mesma duração. Entretanto, a comparação feita em partes distintas dos segmentos e das vogais adjacentes trouxe informações que não poderiam ser dadas pelo estudo do capítulo anterior.

A comparação entre as partes das consoantes glotalizadas com rangeado e das consoantes simples mostrou que as diferenças nos níveis de periodicidade e de $\mathrm{H} 1-\mathrm{H} 2$ diminuem à medida que as consoantes se aproximam das vogais adjacentes (ver figuras 30 e 32), de tal maneira que não há diferenças significativas nas médias dessas propriedades acústicas em nenhuma das partes das vogais adjacentes às consoantes glotalizadas com rangeado e das vogais adjacentes às consoantes simples. A progressão das diferenças nas médias de frequência fundamental e periodicidade das partes das consoantes glotalizadas sem rangeado e das consoantes simples 
Tabela 9 - Diferenças estatísticas, resultados de testes t e tamanhos de efeito $d$ de Cohen para três propriedades acústicas de três partes de mesma duração de vogais adjacentes a consoantes simples e glotalizadas de grupos pareados

\begin{tabular}{|c|c|c|c|c|c|c|c|c|c|}
\hline \multirow{2}{*}{ Frequência fundamental } & $\mathbf{M}^{a}$ & $\mathrm{SD}^{b}$ & $\mathrm{SE}^{c}$ & \multicolumn{2}{|c|}{ Int. Conf. $95 \%^{d}$} & $\mathrm{t}$ & sig. $(2 \text { caudas })^{e}$ & $\mathrm{~d}^{f}$ & Graus de liberdade ${ }^{g}$ \\
\hline & & & & & & & & & \\
\hline \multicolumn{10}{|l|}{ Posição 1} \\
\hline $\begin{array}{l}\text { simples - glot. com rang. }{ }^{h} \\
\text { simples - glot. sem rang. }{ }^{i}\end{array}$ & $\begin{array}{l}-9,76 \\
-11,07\end{array}$ & $\begin{array}{l}-3,75 \\
-0,98\end{array}$ & $\begin{array}{l}-0,40 \\
-0,11\end{array}$ & $\begin{array}{l}-8,97 \\
-10,85\end{array}$ & $\begin{array}{l}-10,56 \\
-11,29\end{array}$ & $\begin{array}{l}-6,15 \\
-7,39\end{array}$ & $\begin{array}{l}<0,001 \\
<0,001\end{array}$ & $\begin{array}{l}-0,16 \\
-0,24\end{array}$ & $\begin{array}{l}85(0) \\
74(0)\end{array}$ \\
\hline \multicolumn{10}{|l|}{ Posição 2} \\
\hline $\begin{array}{l}\text { simples - glot. com rang. } \\
\text { simples - glot. sem rang. }\end{array}$ & $\begin{array}{l}-3,75 \\
-6,96\end{array}$ & $\begin{array}{l}-1,95 \\
-2,49\end{array}$ & $\begin{array}{l}-0,21 \\
-0,30\end{array}$ & $\begin{array}{l}-3,33 \\
-6,37\end{array}$ & $\begin{array}{l}-4,17 \\
-7,55\end{array}$ & $\begin{array}{l}-2,63 \\
-4,44\end{array}$ & $\begin{array}{l}>0,010 \\
<0,001\end{array}$ & $\begin{array}{l}-0,07 \\
-0,15\end{array}$ & $\begin{array}{l}82(0) \\
68(0)\end{array}$ \\
\hline \multicolumn{10}{|l|}{ Posição 3} \\
\hline $\begin{array}{l}\text { simples }- \text { glot. com rang. } \\
\text { simples - glot. sem rang. }\end{array}$ & $\begin{array}{l}-1,31 \\
-1,99\end{array}$ & $\begin{array}{l}-1,90 \\
-2,93\end{array}$ & $\begin{array}{l}-0,21 \\
-0,37\end{array}$ & $\begin{array}{l}-0,90 \\
-1,26\end{array}$ & $\begin{array}{l}-1,73 \\
-2,71\end{array}$ & $\begin{array}{l}-0,87 \\
-1,37\end{array}$ & $\begin{array}{l}0,388 \\
0,175\end{array}$ & $\begin{array}{l}-0,03 \\
-0,04\end{array}$ & $\begin{array}{l}79(0) \\
62(0)\end{array}$ \\
\hline \multicolumn{10}{|l|}{ Periodicidade } \\
\hline \multicolumn{10}{|l|}{ Posição 1} \\
\hline $\begin{array}{l}\text { simples - glot. com rang. } \\
\text { simples - glot. sem rang. }\end{array}$ & $\begin{array}{l}0,0057 \\
0,0014\end{array}$ & $\begin{array}{l}-0,0046 \\
-0,0025\end{array}$ & $\begin{array}{l}-0,0005 \\
-0,0003\end{array}$ & $\begin{array}{l}0,0067 \\
0,0019\end{array}$ & $\begin{array}{l}0,0047 \\
0,0008\end{array}$ & $\begin{array}{l}1,59 \\
0,33\end{array}$ & $\begin{array}{l}0,117 \\
0,743\end{array}$ & $\begin{array}{l}0,17 \\
0,04\end{array}$ & $\begin{array}{l}85(0) \\
74(0)\end{array}$ \\
\hline \multicolumn{10}{|l|}{ Posição 2} \\
\hline $\begin{array}{l}\text { simples - glot. com rang. } \\
\text { simples - glot. sem rang. }\end{array}$ & $\begin{array}{l}0,0012 \\
0,0029\end{array}$ & $\begin{array}{l}-0,0123 \\
-0,0033\end{array}$ & $\begin{array}{l}-0,0013 \\
-0,0004\end{array}$ & $\begin{array}{l}0,0038 \\
0,0037\end{array}$ & $\begin{array}{c}-0,0015 \\
0,0021\end{array}$ & $\begin{array}{l}0,29 \\
0,68\end{array}$ & $\begin{array}{l}0,774 \\
0,497\end{array}$ & $\begin{array}{l}0,02 \\
0,07\end{array}$ & $\begin{array}{l}82(0) \\
68(0)\end{array}$ \\
\hline \multicolumn{10}{|l|}{ Posição 3} \\
\hline $\begin{array}{l}\text { simples - glot. com rang. } \\
\text { simples - glot. sem rang. }\end{array}$ & $\begin{array}{l}0,0051 \\
0,0134\end{array}$ & $\begin{array}{c}0,0209 \\
-0,0133\end{array}$ & $\begin{array}{c}0,0023 \\
-0,0017\end{array}$ & $\begin{array}{l}0,0005 \\
0,0167\end{array}$ & $\begin{array}{l}0,0096 \\
0,0101\end{array}$ & $\begin{array}{l}0,75 \\
2,47\end{array}$ & $\begin{array}{l}0,453 \\
0,016\end{array}$ & $\begin{array}{l}0,05 \\
0,21\end{array}$ & $\begin{array}{l}79(0) \\
62(0)\end{array}$ \\
\hline \multicolumn{10}{|l|}{$\underline{\mathrm{H} 1-\mathrm{H} 2}$} \\
\hline \multicolumn{10}{|l|}{ Posição 1} \\
\hline $\begin{array}{l}\text { simples - glot. com rang. } \\
\text { simples - glot. sem rang. }\end{array}$ & $\begin{array}{l}0,99 \\
0,78\end{array}$ & $\begin{array}{c}-1,23 \\
0,63\end{array}$ & $\begin{array}{c}-0,13 \\
0,07\end{array}$ & $\begin{array}{l}1,25 \\
0,63\end{array}$ & $\begin{array}{l}0,73 \\
0,92\end{array}$ & $\begin{array}{l}2,52 \\
1,92\end{array}$ & $\begin{array}{l}0,014 \\
0,059\end{array}$ & $\begin{array}{l}0,19 \\
0,16\end{array}$ & $\begin{array}{l}85(0) \\
74(0)\end{array}$ \\
\hline \multicolumn{10}{|l|}{ Posição 2} \\
\hline $\begin{array}{l}\text { simples - glot. com rang. } \\
\text { simples - glot. sem rang. }\end{array}$ & $\begin{array}{l}0,02 \\
0,85\end{array}$ & $\begin{array}{l}-1,15 \\
-0,12\end{array}$ & $\begin{array}{l}-0,13 \\
-0,01\end{array}$ & $\begin{array}{l}0,26 \\
0,87\end{array}$ & $\begin{array}{c}-0,23 \\
0,82\end{array}$ & $\begin{array}{l}0,05 \\
2,07\end{array}$ & $\begin{array}{l}0,961 \\
0,042\end{array}$ & $\begin{array}{l}<0,01 \\
0,16\end{array}$ & $\begin{array}{l}82(0) \\
68(0)\end{array}$ \\
\hline \multicolumn{10}{|l|}{ Posição 3} \\
\hline $\begin{array}{l}\text { simples - glot. com rang. } \\
\text { simples - glot. sem rang. }\end{array}$ & $\begin{array}{c}-0,10 \\
0,44\end{array}$ & $\begin{array}{l}-1,43 \\
-0,07\end{array}$ & $\begin{array}{l}-0,16 \\
-0,01\end{array}$ & $\begin{array}{l}0,21 \\
0,46\end{array}$ & $\begin{array}{c}-0,41 \\
0,43\end{array}$ & $\begin{array}{c}-0,23 \\
1,18\end{array}$ & $\begin{array}{l}0,817 \\
0,244\end{array}$ & $\begin{array}{c}-0,02 \\
0,08\end{array}$ & $\begin{array}{l}79(0) \\
62(0)\end{array}$ \\
\hline
\end{tabular}

Notas:

${ }^{a}$ Média ${ }^{b}$ Desvio-padrão ${ }^{c}$ Erro padrão ${ }^{d}$ Intervalo de confiança de $95 \%$ para a média ${ }^{e}$ Significância (duas caudas) ${ }^{f}$ Tamanho de efeito $d$ de Cohen ${ }^{g}$ Valores entre parênteses: diferenças entre o número de casos não identificados das consoantes simples e glotalizadas ${ }^{h}$ Diferenças entre consoantes simples e consoantes glotalizadas com rangeado ${ }^{i}$ Diferenças entre consoantes simples e consoantes glotalizadas sem rangeado 
apresenta padrão semelhante (ver figuras 29 e 31), ainda que as diferenças significativas em frequência fundamental ultrapassem a fronteira das consoantes, atingindo as vogais, e as diferenças significativas em periodicidade se limitem às posições c3 e c2. Estes fatos corroboram a observação de que a glotalização se concentra, com maior intensidade, no início das consoantes em início de palavra (e sílaba) e no final das consoantes em final de palavra (e sílaba), ou seja, nas posições em que não há contato com a vogal adjacente.

O padrão observado nas consoantes glotalizadas da língua Dâw poderia ser explicado, a princípio, pela origem histórica desses segmentos. Martins (2005) defende que as consoantes soantes (e as oclusivas em coda silábica) glotalizadas das línguas Dâw, Hup e Yuhup originaramse da incorporação de traços de oclusivas glotais elididas. As consoantes soantes glotalizadas que se encontram em ataque e coda silábica nas palavras das línguas mencionadas teriam herdado a articulação laríngea de oclusivas glotais precedentes e seguintes, respectivamente. Admitindo ser verdadeira esta hipótese, o padrão descrito no parágrafo anterior se justificaria pela gênese da glotalização nesses segmentos. O processo de redução silábica, discutido no capítulo 7, é uma evidência a favor da hipótese de Martins (2005), entretanto, não há argumentos e demonstrações suficientes para sustentar a proposta. Martins (2005) não propõe um conjunto de mudanças consistentes que teriam ocorrido em contextos bem determinados, mas, em vez disso, trata de contextos muito variáveis e protoformas que não se explicam claramente.

De acordo com Plauché et al. (1998), a concentração ou restrição da glotalização ao início das consoantes soantes em ataque silábico e ao final das consoantes soantes que se encontram em coda silábica é um padrão universal. Gordon e Ladefoged (2001) relatam o mesmo padrão e sugerem que ele possa ser motivado por fatores perceptuais, como o conflito entre a manifestação das propriedades acústicas da glotalização e a necessidade de manter claras e perceptíveis as pistas acústicas de ponto e modo de articulação produzida na região supralaríngea. O padrão temporal da glotalização observado neste capítulo e em outras línguas do mundo pode ser compreendido como o afastamento das propriedades da glotalização, pelo menos de maneira mais intensa, da região de transição de formantes (parte c1). Para alguns segmentos, como as consoantes nasais, a região de transição de formantes contém as pistas acústicas mais importantes para a identificação do ponto de articulação. Outros tipos de segmentos, como as aproximantes palatal (j) e lábio-velar (w), apresentam pistas acústicas de ponto de articulação ao longo de toda a sua extensão. É preciso, portanto, considerar separadamente os diferentes tipos de consoantes soantes ao examinar possíveis restrições baseadas em fatores perceptuais. As diferenças na distribuição dos tipos de glotalização entre as consoantes orais e nasais, examinadas no capítulo 8 , talvez possam ser explicadas pelas diferenças na localização ou na natureza das pistas acústicas mais importantes da articulação supralaríngea. Contudo, apenas um estudo destinado especificamente ao exame deste tema poderia verificar se a manifestação da glotalização ao longo do segmento e a distribuição dos diferentes tipos de glotalização têm realmente motivação perceptual.

Observando a figura 28, nota-se que as médias de frequência fundamental das partes c3 e c2 são mais baixas para as consoantes glotalizadas com rangeado do que para as consoantes simples 
e que a relação se inverte na parte c1 e, especialmente, na parte v1 das vogais adjacentes. Os testes estatísticos mostraram diferenças significativas apenas em v1 (ver tabela 9), com tamanho de efeito $d$ de Cohen pequeno, mas a tendência de subida de frequência fundamental na transição da consoante glotalizada para a vogal parece ser consistente. Como dito no capítulo anterior, uma das principais características das consoantes glotalizadas sem rangeado, especialmente daquelas que possuem voz áspera, é o aumento de frequência fundamental. Os testes estatísticos deste capítulo indicaram que as diferenças nas médias de frequência fundamental de todas as partes das consoantes glotalizadas sem rangeado são superiores às registradas para as mesmas partes das consoantes simples do mesmo grupo pareado (ver tabela 8). A relação também se estende às partes v1 e v2, mais próximas das consoantes glotalizadas, das vogais adjacentes (ver tabela 9). Desta maneira, é possível apontar como sendo comum às consoantes glotalizadas, com ou sem rangeado, o aumento da frequência fundamental, que não se restringe às consoantes, mas também afeta as vogais.

No capítulo 2, comentou-se que um dos mecanismos fisiológicos responsáveis pela produção da fonação rangeada é a compressão longitudinal das pregas vocais, o que resulta no seu afrouxamento e também na redução da frequência fundamental. Os gráficos das figuras 28 e 30 mostram, respectivamente, que a queda de periodicidade é muito maior e que a frequência fundamental é ligeiramente inferior nas partes c 3 e c 2 das consoantes glotalizadas com rangeado, em relação às consoantes simples correspondentes. Ambas as informações indicam, portanto, que a fonação rangeada é produzida de maneira mais intensa nas partes mencionadas. Sendo a fonação rangeada incompatível com o aumento de frequência fundamental, não causa surpresa verificar que o aumento de frequência fundamental ocorre nas partes c1 e v1. Entretanto, não há, aparentemente, nenhuma razão de natureza articulatória ou perceptual para o aumento de frequência fundamental após a produção mais intensa da fonação rangeada. Como ambos os tipos de consoantes glotalizadas, conjuntamente com as vogais adjacentes, apresentam aumento de frequência fundamental, parece razoável propor que esta é uma característica particular das consoantes glotalizadas da língua Dâw ${ }^{2}$.

2 A elevação nos níveis de frequência fundamental das consoantes glotalizadas e das vogais adjacentes não provocam restrições no sistema tonal da língua Dâw, conforme demonstrado na seção 6.2. 


\section{Interações entre a glotalização e o sistema tonal}

\subsection{O sistema tonal e acentual da língua Dâw}

A língua Dâw possui um sistema tonal restrito com possibilidades de distinção lexical e funcional. Segundo Martins (2004, p. 78-79), as palavras classificam-se como tonais ou atonais, admitindo as primeiras os tons de contorno ascendente e descendente. Desta maneira, há um sistema de distinção baseado em três paradigmas. A tabela 10, abaixo, contém alguns pares mínimos e análogos, coligidos por Martins (2004, 84-85), que exemplificam as possibilidades de distinção.

Tabela 10 - Pares mínimos e análogos de palavras atonais e tonais com os tons descendente e ascendente, segundo Martins (2004, 84-85)

\begin{tabular}{|c|c|c|c|c|c|c|}
\hline \multicolumn{3}{|c|}{ Atonal } & \multicolumn{2}{|c|}{ Tom descendente } & \multicolumn{2}{|c|}{ Tom ascendente } \\
\hline & Transcrição & Tradução (PB) & Transcrição & Tradução (PB) & Transcrição & Tradução (PB) \\
\hline 1. & curg & doer & cûg & rim & cǔg & malária \\
\hline 2. & ka? & suspender & kâ & bocejar & kă? & amarrar anzol \\
\hline 3. & pah & latir & pâ & terra firme & pǎh & saber \\
\hline 4. & pr? & esfolado & $\mathrm{p} \hat{\gamma}$ & caatinga & přr? & avó \\
\hline
\end{tabular}

Notas:

As palavras do conjunto (1) têm forte relação semântica e provavelmente a mesma origem.

O sistema tonal da língua Dâw apresenta dois tipos de restrição. Um deles relaciona-se com a posição da sílaba na palavra e a natureza morfológica da palavra, enquanto o outro baseia-se no contexto segmental e no formato silábico. Na língua Dâw, somente as sílabas finais das palavras monomorfêmicas apresentam tom fonêmico. Contudo, cabe lembrar que a maioria das palavras da língua é monossilábica e monomorfêmica (ver subseção 1.1.1). Mesmo no conjunto bastante limitado de palavras com mais de uma sílaba e formadas por mais de um morfema, as palavras possuem quase sempre um tom apenas. As exceções são algumas palavras compostas ou constituídas por uma palavra lexical e um morfema funcional. 
Figura 34 - Oscilograma (acima) e curva de frequência fundamental (abaixo) da palavra /wâm/

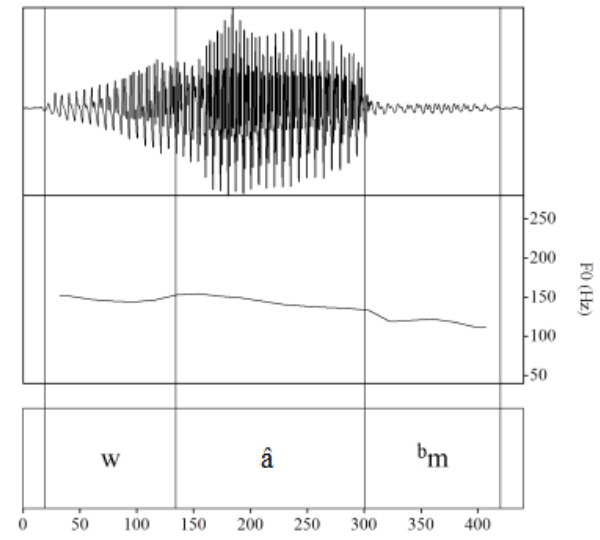

Tempo (ms)
Figura 35 - Oscilograma (acima) e curva de frequência fundamental (abaixo) da palavra /w? ăm?

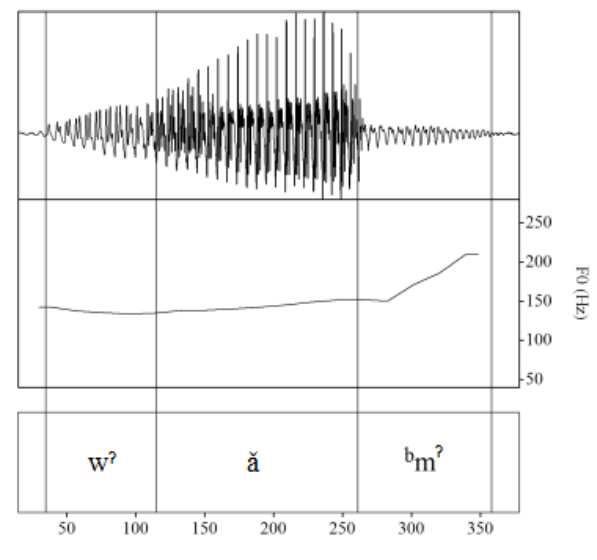

Nas palavras livres, observam-se, em geral, dois formatos silábicos: CV: e CVC (MARTINS, 2004, p. 69). Todas as sílabas finais com formato CV: têm necessariamente tom descendente e, por conseguinte, não admitem distinção. Por outro lado, as sílabas finais CVC têm comportamentos diferentes de acordo com o vozeamento da consoante que ocupa a coda silábica. Se esta consoante é vozeada, a sílaba pode ser atonal ou tonal com qualquer um dos dois tons de contorno (MARTINS, 2004, p. 83). Entretanto, se a consoante final é desvozeada, não pode ocorrer o tom descendente (MARTINS, 2004, p. 83). Martins (2004) também leva em consideração o traço [ \pm sonorante] para descrever as restrições dos tons em sílabas CVC que se encontram em final de palavra, porém, dado o inventário fonológico da língua, parece haver redundância na descrição ${ }^{1}$. Os morfemas funcionais, que têm geralmente a forma $\mathrm{VC}$, podem ser atonais ou portar os tons descendente ou ascendente, não importando, de acordo com Martins (2004), se a consoante final é vozeada ou desvozeada.

As figuras 34 e 35 representam um par análogo de palavras pronunciadas em isolamento, /wâm/ ("macaco cutiporó") e /wª̆m?/ ("embaúba"), que têm os tons descendente e ascendente, respectivamente. Ainda que a consoante glotalizada $/ \mathrm{m}^{2} /$ pudesse elevar a frequência fundamental na última parte da vogal /a/ da palavra /wª̆m? /, conforme discutido no capítulo 5 , este fator microprosódico não poderia explicar a passagem do tom baixo ao tom alto que se estende por toda a vogal.

As figuras 36 e 37 ilustram duas sentenças que contêm um par mínimo de palavras, uma delas atonal e a outra com tom descendente. A sentença /n£g brh/ (ver figura 36), que significa

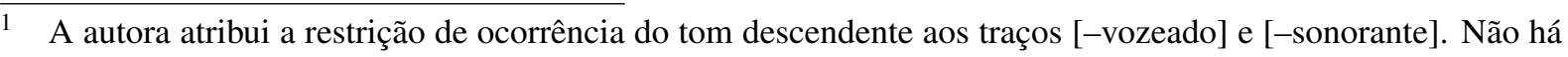
consoantes soantes desvozeadas em Dâw, o que significa que todo segmento com o traço [-vozeado] também tem o traço [-sonorante]. Os traços presentes nos contextos que admitem a ocorrência do tom descendente são [+vozeado] e [ \pm sonorante]. Novamente, na língua Dâw, todo segmento com o traço [+vozeado] pode ter o traço [+sonorante] ou [-sonorante]. Desta maneira, o traço [ \pm sonorante] simplesmente segue as possibilidades dadas pelo traço [ \pm vozeado], de tal modo que apenas o último realmente determina contextos distintos. 
Figura 36 - Oscilograma (acima) e curva de frequência fundamental (abaixo) da frase /neg brh/

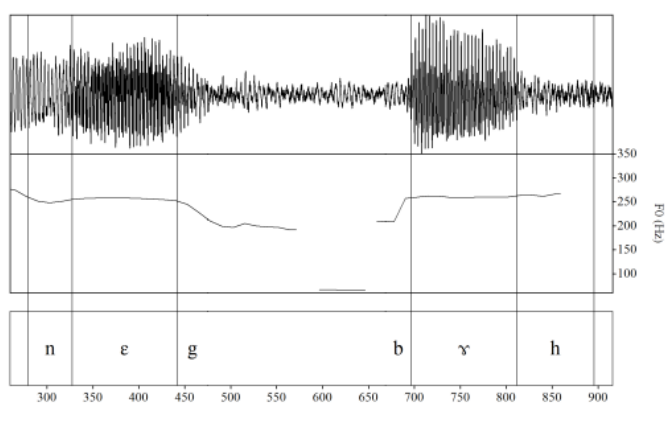

Figura 37 - Oscilograma (acima) e curva de frequência fundamental (abaixo) da frase $/ n \hat{\varepsilon} g \mathrm{brh} /$

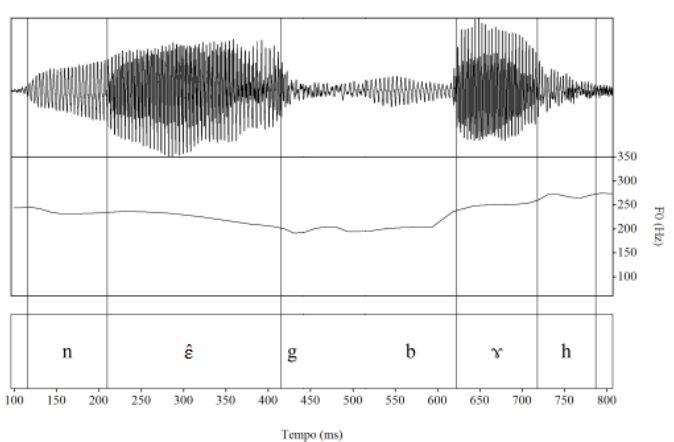

"a gordura derramou", contém a palavra /neg/ ("gordura"), que é atonal e se manifesta com tom alto. Por outro lado, na frase /nk̂g brh/ (“o mel derramou”), mostrada na figura 37, encontra-se a palavra /nêg/ ("mel”), que possui tom descendente. Além da diferença nas curvas de frequência fundamental, nota-se diferença na duração das duas vogais: $114 \mathrm{~ms}$ para a vogal da palavra atonal e $205 \mathrm{~ms}$ para a vogal da palavra com tom descendente. $\mathrm{O}$ alongamento das vogais com tons de contorno é relatado por Martins (2004, p. 79) e pôde ser notado em diversas gravações. Entretanto, a confirmação deste fato fonético, que também se observa em outras línguas sem parentesco com a língua Dâw (GORDON, 2001), requer um estudo elaborado especificamente para isso.

Ao comparar as formas das palavras quando elas são pronunciadas em isolamento e em contexto de sentença, não se verificam diferenças nos tons de contorno, como demonstram os diagramas da figura 38 à 41 . O tom descendente da palavra /mỗ/ ("inambu”) é observado tanto na sua pronúncia isolada, representada na figura 38 , quanto na frase $/ 2 a-w^{2} \gamma j^{2} \mathrm{~m}^{2} \tilde{\tilde{\varepsilon}}$ ? m $\hat{\tilde{\partial}} /$ ("essa palavra é um inambu"), que é ilustrada na figura 39. De maneira semelhante, como mostram as figuras 40 e 41, o tom ascendente da palavra /lăj’/ ("pescar") manifesta-se igualmente na sua pronúncia isolada e dentro da sentença /Rãh lăj’/ ("eu pesquei”). A existência de pares mínimos e análogos e a consistência dos tons em diferentes contextos reforçam o argumento de Martins (2004) de que existe um sistema tonal na língua Dâw.

Martins (2004) defende que a língua Dâw possui não apenas um sistema tonal, mas também um sistema acentual (MARTINS, 2004, p. 90). Em palavras monomorfêmicas, tom e acento recaem na mesma sílaba, ou seja, a última. A palavra dissilábica /o. 'jªh/ (“mentira" ou "mentir") não possui tom lexical e, quando pronunciada em isolamento, como demonstra a figura 42, apresenta tom baixo na primeira sílaba e tom alto na última sílaba. Além disso, nota-se que a intensidade acústica é mais elevada na última sílaba do que na primeira sílaba, como se vê na curva de intensidade acústica sobreposta ao oscilograma da figura 42, e que a vogal /a/ (cerca de 120 ms) é mais longa da que a vogal /o/ (cerca de 80 ms). De acordo com Martins (2004, p. 91), as sílabas acentuadas têm vogais com maior frequência fundamental, intensidade acústica e duração, exatamente o que se observa na última sílaba da palavra /o.'jªh/ . Apesar de haver 


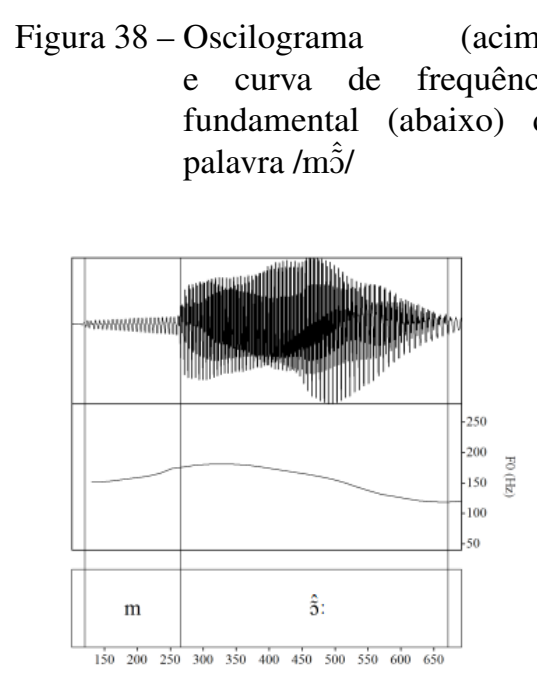

Tempo (ms)
Figura 39 - Oscilograma (acima) e curva de frequência fundamental (abaixo) da frase $/ R a-w^{2} \gamma j^{2} m^{2} \tilde{\varepsilon} ? \mathrm{~m} \tilde{\tilde{J}} /$

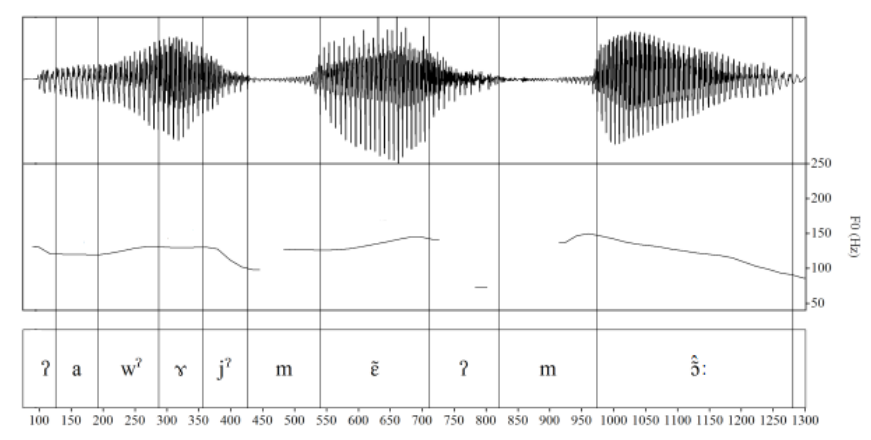

Tempo (ms)

Figura 41 - Oscilograma (acima) e curva de frequência fundamental (abaixo) da frase /Tãh lăj’/
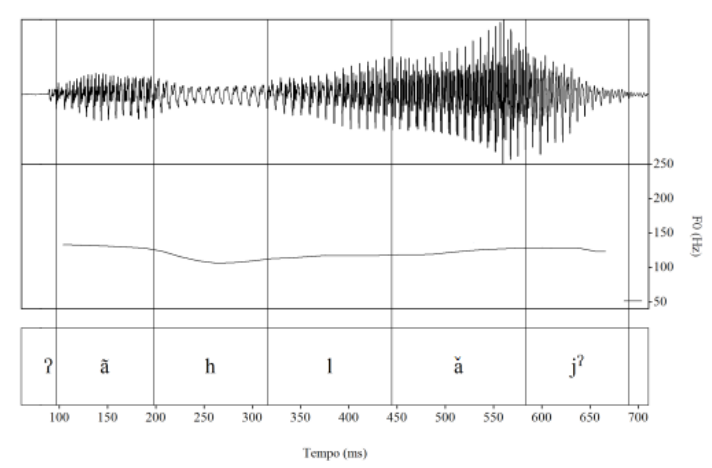

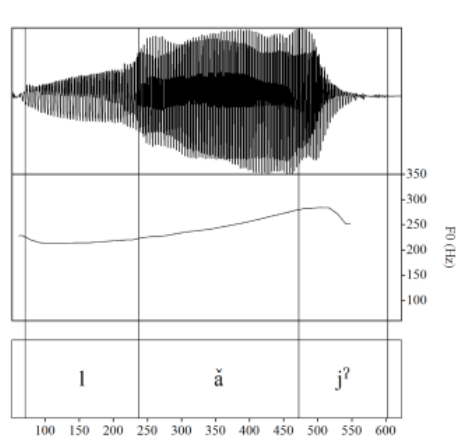

Tempo (ms) (acima) e curva de frequência fundamental (abaixo) da palavra /lǎj $?$

muitas evidências para a proposta de Martins (2004) a respeito da existência de um sistema acentual, como exemplifica a palavra /o.' $\mathrm{j}^{2} \mathrm{ah} /$, seria ainda possível interpretar o aumento de frequência fundamental em algumas sílabas como a manifestação de um tom alto lexical, que se distinguiria dos tons de contorno ascendente e descendente.

As palavras /tih/ (pronome da terceira pessoa do singular) e /nũh/ ("cabeça") são transcritas como atonais por Martins (2004). Nas frases /tih Pã/ ("ele dormiu”) e /nũh brd/ ("a cabeça virou"), que podem ser conferidas nas figuras 43 e 44, respectivamente, observa-se que ambas

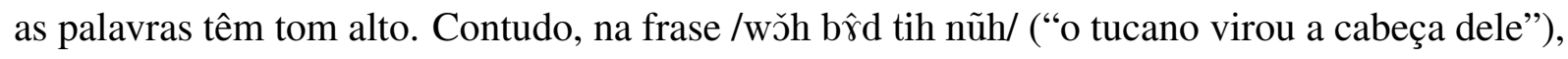
/tih/ possui tom baixo e /nũh/ tem tom ascendente (ver a figura 45). Se as palavras mencionadas tivessem tom alto lexical, em vez de serem simplesmente acentuadas, seria esperada a repetição do que se encontrou nas frases das figuras 43 e 44, ou seja, tom alto. O exame das palavras inseridas em contexto de sentença reforça o argumento de Martins (2004) de que a língua Dâw possui um sistema tonal e acentual, não sendo fonêmicos os tons observados nas palavras denominadas atonais. É possível que os tons não-fonêmicos (baixo e alto) tenham relação com a 
Figura 42 - Oscilograma com curva de intensidade acústica sobreposta (acima) e curva de frequência fundamental (abaixo) da palavra /o.'j?ah/

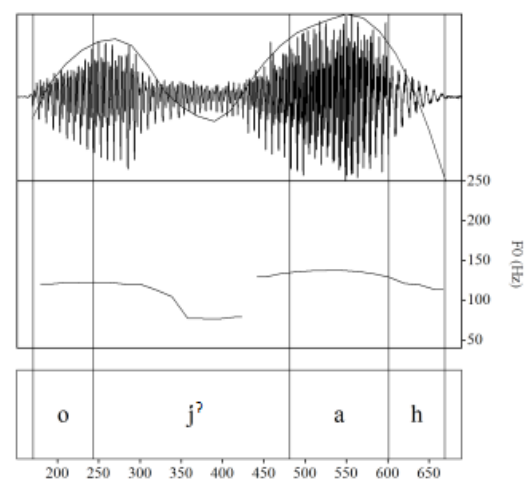

Tempo (ms)

Figura 43 - Oscilograma com curva de intensidade acústica sobreposta (acima) e curva de frequência fundamental (abaixo) da frase /tih Pã/

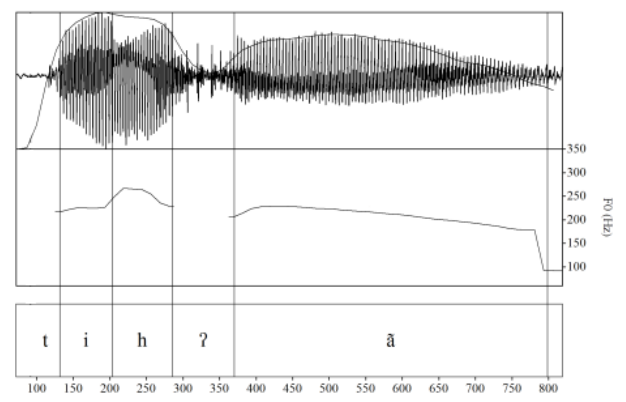

Tempo (ms)
Figura 44 - Oscilograma com curva de intensidade acústica sobreposta (acima) e curva de frequência fundamental (abaixo) da palavra /nũh brd/

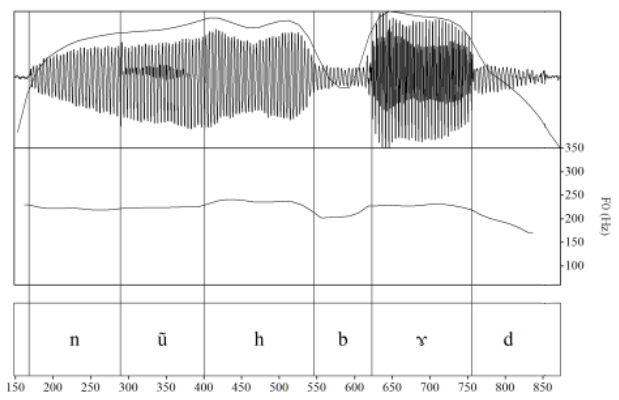

Tempo (ms)

Figura 45 - Oscilograma com curva de intensidade acústica sobreposta (acima) e curva de frequência fundamental (abaixo) da palavra /wǒh b̂̂rd tih nũh/

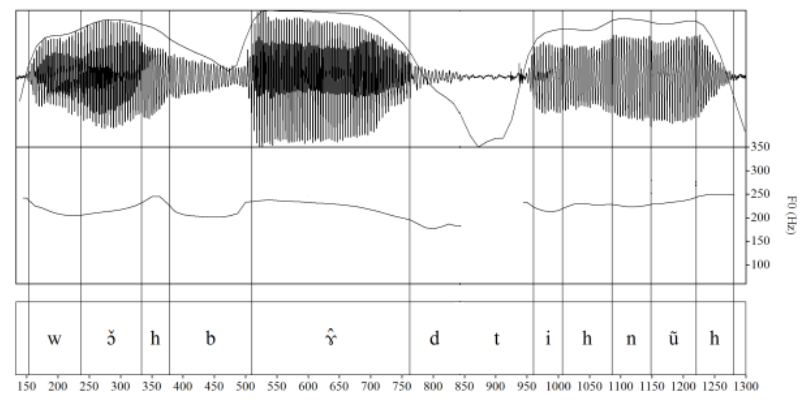


estrutura prosódica das sentenças, mas somente estudos voltados especificamente à análise deste aspecto da fonologia da língua Dâw pode ajudar a solucionar a questão.

\subsection{A coexistência de tom e glotalização}

Nos capítulos 4 e 5, demonstrou-se que uma das características mais importantes das consoantes glotalizadas, especialmente daquelas que são produzidas com voz áspera, é a alteração nos níveis de frequência fundamental. Como se viu no capítulo 5, a alteração nos níveis de frequência fundamental não se restringe apenas às consoantes glotalizadas, mas também se estende às vogais adjacentes. Os testes estatísticos apontaram para um aumento significativo nas médias de frequência fundamental das partes das vogais mais próximas das consoantes glotalizadas (ver tabela 9). Dado que as distinções tonais se baseiam nos níveis de frequência fundamental das vogais, como podem coexistir duas entidades fonológicas - glotalização e tom - que se caracterizam ou se manifestam por meio de diferentes níveis, em alguns casos, potencialmente conflitantes, da mesma propriedade acústica?

A figura 46 mostra o oscilograma e a curva de frequência fundamental da palavra $/ \mathrm{w}^{2} \mathrm{en} /$ (“sucuri”), que possui uma consoante glotalizada na posição de ataque silábico $\left(/ \mathrm{w}^{2} /\right)$ e não apresenta marcação tonal. Há uma pequena elevação no nível de frequência fundamental do princípio da vogal $/ \mathrm{e}^{2}$, mas a curva de frequência fundamental admite pouca variação (cerca de $10 \mathrm{~Hz}$ ) no intervalo correspondente à vogal. Na palavra $/ \mathrm{w}^{2} \hat{\gamma} /$ ("abelha grande"), representada na figura 47, há também uma consoante glotalizada em ataque silábico, porém a sílaba possui tom descendente. Como as consoantes glotalizadas em ataque silábico elevam a frequência fundamental nas partes iniciais das vogais adjacentes e o tom descendente é formado por um tom alto, no início das vogais, e um tom baixo, no final das vogais, não há qualquer incompatibilidade entre as propriedades da consoante glotalizada $/ \mathrm{w}^{2} / \mathrm{e}$ do tom descendente na palavra $/ \mathrm{w}^{2} \hat{\gamma} /$. Por outro lado, poderia haver conflito entre a elevação na frequência fundamental provocada pelas consoantes glotalizadas em posição de ataque silábico e o tom ascendente, porque este se define pela passagem de um tom baixo, no início das vogais, a um tom alto, no final das vogais. A figura 48 mostra, contudo, que a consoante glotalizada sem rangeado $/ w^{2} /$ da palavra $/ w^{2} \check{\gamma} j^{2} /$ ("palavra" ou "falar") não apresenta aumento nos níveis de frequência fundamental e não o produz em nenhuma parte da vogal adjacente $/ \check{\gamma} /$, que porta o tom ascendente.

Na figura 50, observa-se, mais uma vez, uma palavra constituída por uma sílaba atonal, /dej?/ ("torto"), porém, neste caso, a consoante glotalizada ( $j^{?}$ ) encontra-se em coda silábica. A consoante $/ \mathrm{j}^{2} /$ apresenta rangeado em sua parte final, como se pode ver no oscilograma e na interrupção da curva de frequência fundamental, e não provoca aumento perceptível de frequência fundamental. Na palavra $/ \mathrm{w}^{2} \check{\gamma}_{\mathrm{j}}$ \% , que tem tom ascendente, há uma consoante glotalizada $\left(\mathrm{j}^{2}\right)$ em posição de coda silábica (ver figura 48). Ao contrário do que ocorre com a consoante inicial $\left(\mathrm{w}^{2}\right)$, comentada no parágrafo anterior, o possível aumento de frequência fundamental

\footnotetext{
2 Provavelmente provocada pela consoante glotalizada (ver capítulo 5).
} 
Figura 46 - Oscilograma (acima) e curva de frequência fundamental (abaixo) da palavra $/ \mathrm{w}^{2} \mathrm{en} /$ pronunciada por VT

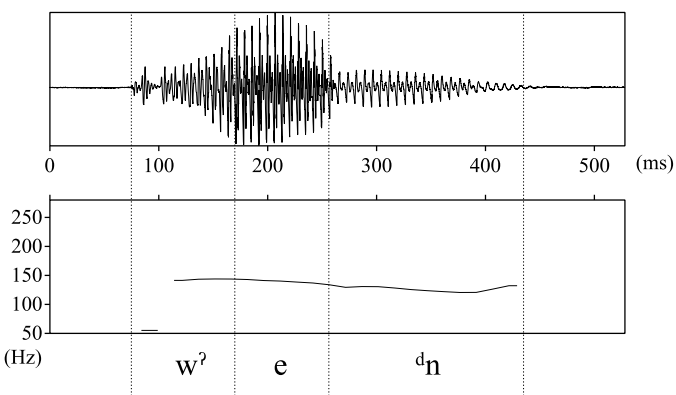

Figura 48 - Oscilograma (acima) e curva de frequência fundamental (abaixo) da palavra $/ \mathrm{w}^{2} \check{\gamma} \mathrm{j}^{2} /$ pronunciada por SL

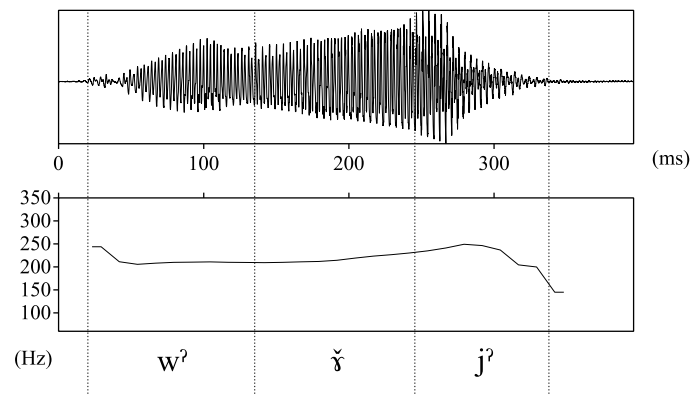

Figura 47 - Oscilograma (acima) e curva de frequência fundamental (abaixo) da palavra $/ \mathrm{w}^{2} \hat{\gamma} /$ pronunciada por ES

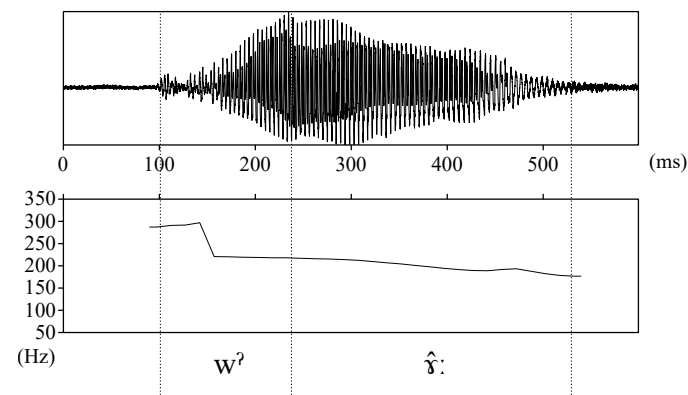

Figura 49 - Oscilograma (acima) e curva de frequência fundamental (abaixo) da palavra / $\mathrm{w}^{2} \hat{\mathrm{o} j} \mathrm{P} /$ pronunciada por MT

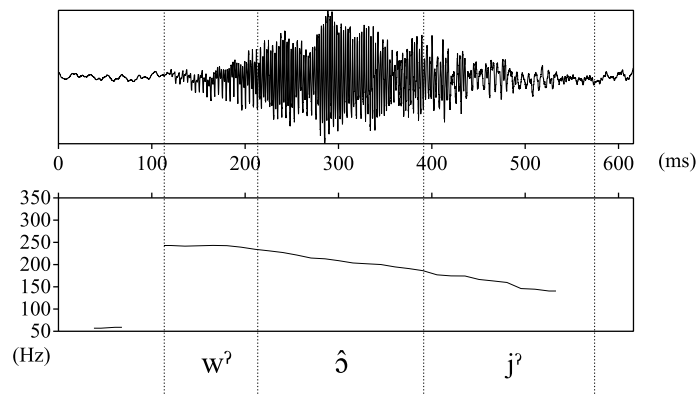

causado pela consoante glotalizada $/ \mathrm{j}^{\mathrm{T}} /$ converge com o tom alto esperado no final de uma vogal com tom ascendente. $\mathrm{O}$ conflito entre a glotalização e o tom, no que diz respeito à frequência fundamental, poderia ocorrer no contexto de uma sílaba com tom descendente (tom alto no início da vogal e tom baixo no final da vogal) e com uma consoante glotalizada na sua coda (aumento de frequência fundamental no final da vogal). Entretanto, a figura 49 mostra que a consoante glotalizada presente na coda silábica $\left(j^{2}\right)$ da palavra /wº̂j ${ }^{2} /$ ("voz do guariba") não manifesta em si mesma e não provoca aumento de frequência fundamental na vogal adjacente.

Os exemplos tratados nos parágrafos anteriores indicam que, em caso de conflito potencial entre a glotalização e os tons lexicais, os níveis de frequência fundamental determinados pelos tons prevalecem sobre o aumento de frequência fundamental provocado pelas consoantes glotalizadas. Ainda que o aumento nos níveis de frequência fundamental seja uma característica fonética importante das consoantes glotalizadas, sobretudo daquelas que possuem voz áspera (ver capítulo 4), existem outras propriedades acústicas que permitem distinguir as consoantes simples e glotalizadas, mas as distinções tonais dependem exclusivamente da frequência fundamental. Desta maneira, em razão da necessidade de manter as distinções fonológicas, parece compreensível que se priorizem os níveis de frequência fundamental definidos pelos tons lexicais.

Em alguns casos, o aumento na frequência fundamental das consoantes glotalizadas é deslocado para o seu início, quando em posição de ataque silábico, ou para o seu fim, quando em posição de coda silábica, não afetando, portanto, a curva de frequência fundamental da 
Figura 50 - Oscilograma (acima) e curva de frequência fundamental (abaixo) da palavra /dej?/ pronunciada por WD

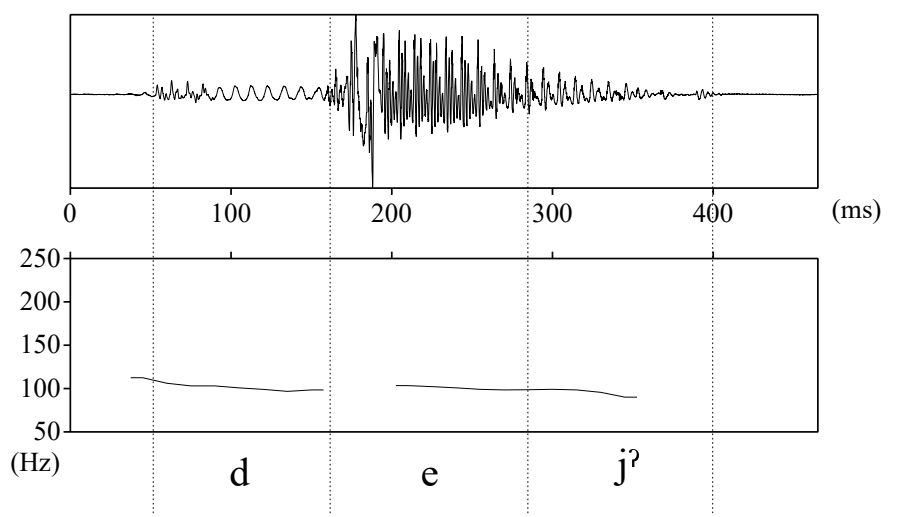

Figura 51 - Oscilograma (acima) e curva de frequência fundamental (abaixo) da palavra $/ \mathrm{w}^{2} \check{\gamma}_{\mathrm{j}} \mathrm{P} /$ pronunciada por MT

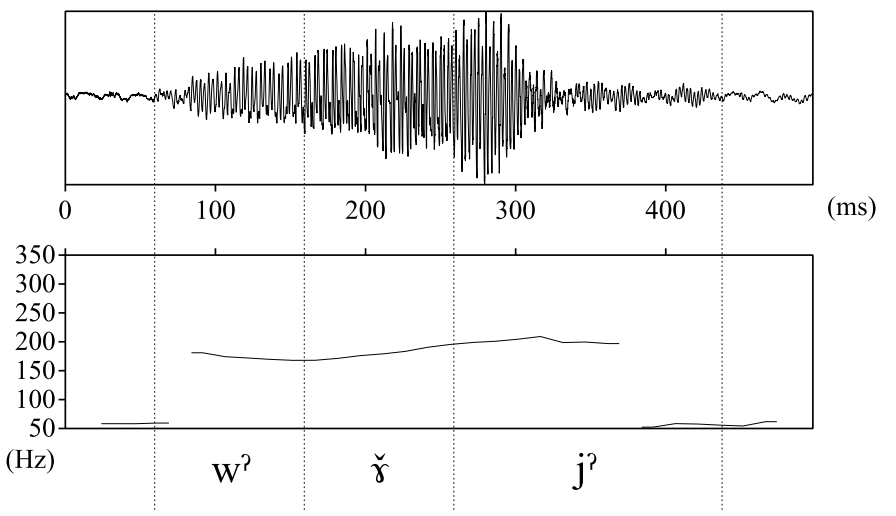

vogal adjacente. A figura 51 exemplifica um desses casos: a consoante glotalizada presente no ataque silábico $\left(\mathrm{w}^{2}\right)$ da palavra $/ \mathrm{w}^{2} \check{\gamma} \mathrm{j}^{?} /$ apresenta aumento de frequência fundamental na sua parte inicial e não afeta a vogal vizinha, que porta o tom ascendente. Em vez de suprimir uma das características das consoantes glotalizadas, produz-se um deslocamento que possibilita a coexistência da glotalização e dos tons lexicais.

Como as consoantes glotalizadas sem rangeado dependem mais dos níveis de frequência fundamental do que as consoantes glotalizadas com rangeado (ver capítulo 4) para serem identificadas e distinguidas das consoantes simples, é possível imaginar que, em contextos de conflito potencial entre a glotalização e os tons lexicais, as consoantes glotalizadas tendem a apresentar formas com rangeado. No corpus deste trabalho, contabilizam-se 62 casos que apresentam os contextos mencionados. As consoantes glotalizadas têm formas com rangeado em apenas 28 deles, ou seja, em menos da metade dos casos. Embora os tons lexicais afetem as características fonéticas das consoantes glotalizadas, anulando ou deslocando a elevação nos níveis de frequência fundamental, não há evidências de que os tons favorecem ou desfavorecem nenhuma uma das formas da glotalização. 


\section{7}

\section{O processo de redução silábica e o}

\section{surgimento das consoantes glotalizadas}

\subsection{O processo de redução silábica}

Martins (2004) descreve um fenômeno morfofonológico denominado redução silábica (MARTINS, 2004, p. 106-114). A autora trata de diferentes tipos de redução silábica, que compreendem, por exemplo, apagamento de rima (MARTINS, 2004, p. 109-110), de oclusiva glotal (MARTINS, 2004, p. 111-113) e de consoantes adjacentes idênticas (MARTINS, 2004, p. 114), mas este capítulo limita-se a discutir os casos relevantes para o estudo da glotalização. O tipo de redução silábica que interessa a este trabalho aplica-se principalmente a formas pronominais acrescidas do sufixo de foco $\{-\mathrm{V} P\}^{1}$, caso afetado $\left\{-\check{\tilde{u}} j^{2}\right\}$ e genitivo $\{-\hat{\tilde{\varepsilon}}\}$ (MARTINS, 2004, p. 106). O processo consiste no apagamento do ataque e do núcleo do morfema pronominal e na adição da coda deste à posição de ataque do sufixo:

1. $\mathrm{C}_{1} \mathrm{~V}_{1} \mathrm{C}_{2}$ (pronome) $+\mathrm{V}_{2} \mathrm{C}_{3}$ (sufixo) $\rightarrow \mathrm{C}_{2} \mathrm{~V}_{2} \mathrm{C}_{3}$ (forma reduzida)

O processo é opcional em todos os casos, salvo para o pronome da primeira pessoa do singular focalizado e o pronome da segunda pessoa do singular no caso afetado, que só podem ocorrer na forma reduzida ( $2 \mathrm{~b}$ e $3 \mathrm{~b}$, respectivamente):

2a. Pãh (1SG) + -ã̃ (FOC) $\rightarrow$ *?ã.'hã? (forma não-reduzida) ${ }^{2}$

2b. ?ãh (1SG) + -ã? (FOC) $\rightarrow$ hã? (forma reduzida)

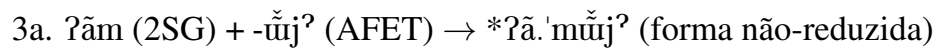

3b. ?ãm (2SG) +- - $\tilde{\tilde{u}}^{2}{ }^{2}$ (AFET) $\rightarrow \mathrm{m}^{2} \tilde{\tilde{u}}^{2}{ }^{2}$ (forma reduzida)

Quando o ataque silábico do pronome é formado por uma oclusiva glotal e a sua coda por uma consoante soante simples, esta se torna glotalizada e se insere no ataque silábico do sufixo. O processo é esquematizado pela seguinte fórmula:

1 A qualidade da vogal $\mathrm{V}$ é a mesma da última vogal da palavra afixada, por exemplo: / $/$, quando afixado a /jon/ ("tamanduá"), e /-u/, quando afixado a /j'ãm.xu?/ (“onça").

2 O asterisco (*) indica que a forma não é permitida ou atestada na língua de acordo com Martins (2004). 
4. $? \mathrm{~V}_{1} \mathrm{~S}$ (pronome) $+\mathrm{V}_{2} \mathrm{C}_{1}$ (sufixo) $\rightarrow \mathrm{S}^{2} \mathrm{~V}_{2} \mathrm{C}_{1}$ (forma reduzida)

A representação em (3b) da redução silábica obrigatória na formação do pronome da segunda pessoa do singular no caso afetado exemplifica o surgimento de uma consoante glotalizada no ataque da forma reduzida. A forma reduzida do pronome da segunda pessoa do singular no caso genitivo é outro exemplo comum do surgimento de uma consoante glotalizada em razão do processo de redução silábica:

\section{Pãm $(2 \mathrm{SG})+-\hat{\tilde{\varepsilon}} \mathrm{f}(\mathrm{GEN}) \rightarrow \mathrm{m}^{2} \hat{\tilde{\varepsilon}}^{\hat{\varepsilon}}($ forma reduzida $)$}

Martins (2004) descreve a redução silábica e arrola as transcrições de alguns exemplos do processo, porém não apresenta oscilogramas, espectrogramas ou qualquer figura em que se possa comparar a consoante simples do pronome sem sufixo com a consoante glotalizada da forma reduzida do pronome com sufixo. Como dito na seção 1.2, as gravações feitas para o presente trabalho incluem palavras e frases destinadas ao exame da redução silábica de um ponto de vista fonético. Os oscilogramas e espectrogramas das palavras /tih/ ("ele”) e /tih $\hat{\tilde{\varepsilon}}$ f/ ("ele" + GEN ou, simplesmente, "dele") estão representados nas figuras 52 e 53, respectivamente. A diferença entre as duas palavras reside no morfema $\{-\hat{\tilde{\varepsilon}}\}$, que é sufixado ao pronome /tih/. A figura 54 mostra o oscilograma e o espectrograma do pronome da segunda pessoa do singular/Rãm/, que possui uma oclusiva glotal no ataque silábico e uma consoante soante simples em sua coda silábica. Considerado o processo de redução silábica descrito em (4), espera-se que, na formação da variante reduzida do pronome da segunda pessoa do singular no caso genitivo, seja acrescida uma consoante glotalizada correspondente à coda de $/$ R̃am/, ou seja, $/ \mathrm{m} \%$, ao morfema $\{-\hat{\tilde{\varepsilon}}\}$. Na figura 55, observa-se exatamente o esperado: a consoante em ataque silábico é uma consoante nasal bilabial que apresenta as características da fonação rangeada, como a irregularidade na duração dos ciclos glotais e na forma de onda (ver capítulo 4).

Figura 52 - Oscilograma (acima) e espectrograma (abaixo) da palavra /tih/ pronunciada por ES

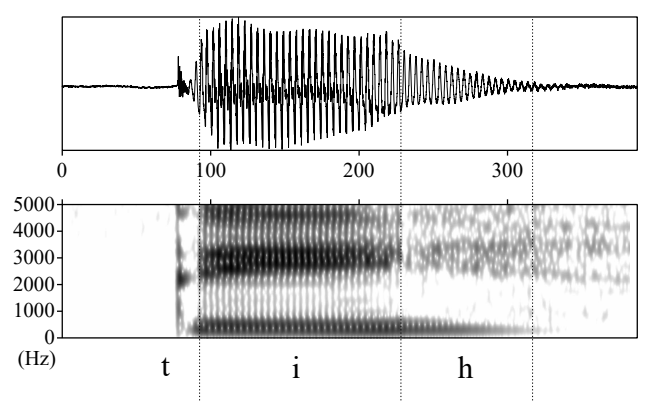

Figura 53 - Oscilograma (acima) e espectrograma (abaixo) da palavra /tihễ $f /$ pronunciada por ES

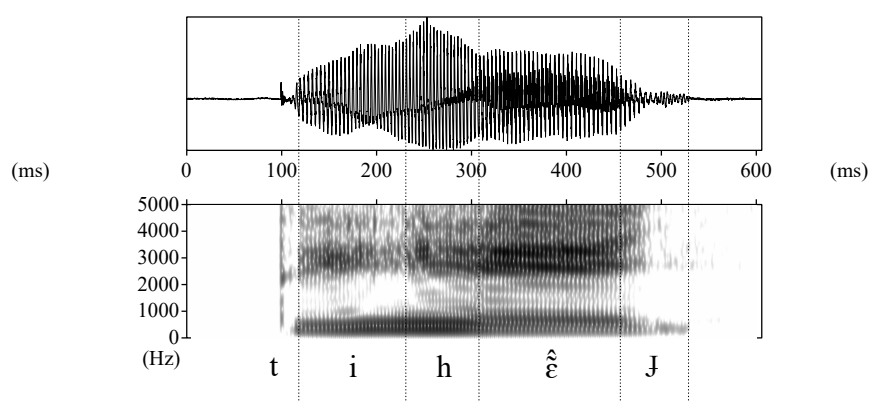

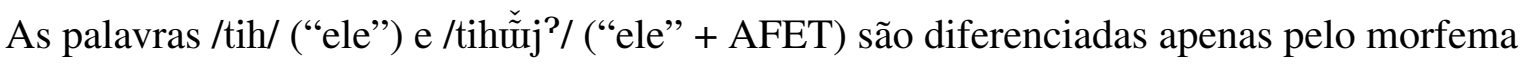
$\left\{\right.$ - $\left.\tilde{\tilde{u}}_{j}{ }^{2}\right\}$ (AFET). A comparação das figuras 52 e 56 mostra que o morfema mencionado tem a forma esperada. A forma reduzida do pronome da segunda pessoa do singular no caso afetado 
Figura 54 - Oscilograma (acima) e espectrograma (abaixo) da palavra /?ãm/ pronunciada por ES
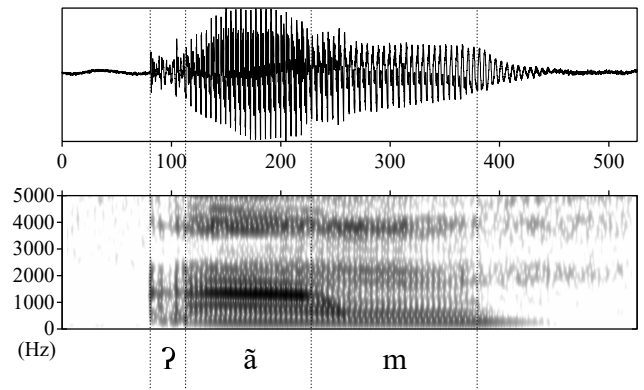

Figura 55 - Oscilograma (acima) e espectrograma (abaixo) da palavra $/ \mathrm{m}^{2} \hat{\tilde{\varepsilon}} \mathrm{f} /$ pronunciada por ES

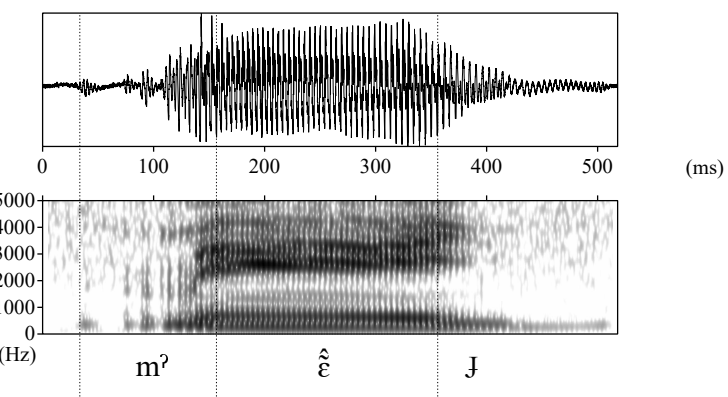

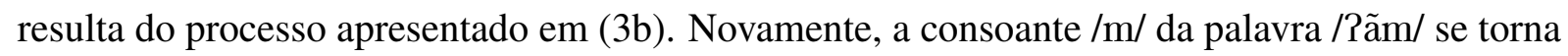
glotalizada e se transfere para o ataque silábico do sufixo, neste caso, $\left\{-\check{\tilde{\tilde{u}}} j^{2}\right\}$. Na figura 57 , observa-se que a consoante inicial $/ \mathrm{m}^{2} /$ é glotalizada e apresenta fonação rangeada, identificada, dentre outras coisas, pela irregularidade na duração dos ciclos glotais.

Figura 56 - Oscilograma (acima) e espectrograma

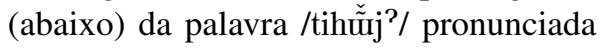
por ES
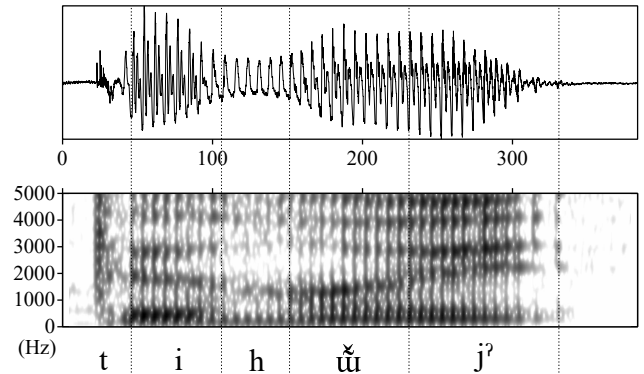

(ms)
Figura 57 - Oscilograma (acima) e espectrograma (abaixo) da palavra $/ \mathrm{m}^{2} \tilde{\tilde{u}} j^{2} /$ pronunciada por ES

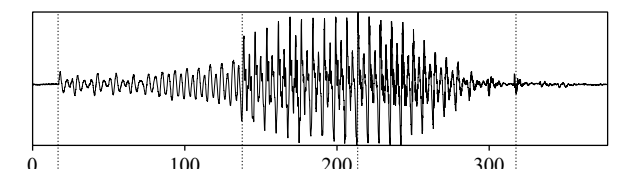

(ms)

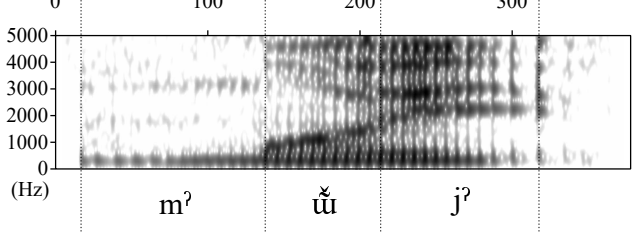

As avaliações qualitativas exemplificadas nos parágrafos anteriores foram feitas com gravações de 11 falantes nativos da língua Dâw, que continham a pronúncia de palavras isoladas e frases. O resultado, como visto, confirmou a descrição de Martins (2004), embora seja importante notar que todos os falantes pronunciaram somente a forma reduzida do pronome da segunda pessoa do singular no caso genitivo, que, de acordo com a autora, também poderia ocorrer na

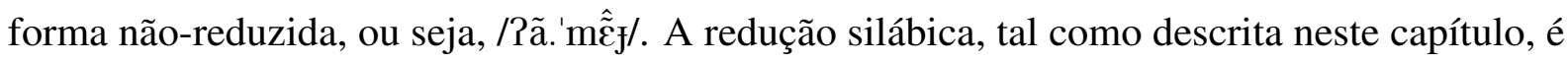
pouco produtiva, restringe-se a poucos morfemas e não parece ser comum encontrar variações das formas reduzida e não-reduzida. Cabe, portanto, questionar se a redução silábica consiste realmente em um processo sincrônico ou se a sua natureza é diacrônica.

O processo esquematizado em (4) não mostra todo o percurso do estado inicial ao estado final. Nas formas não-reduzidas, o acento recai na última silaba (ver capítulo 6), que é produto da ressilabificação: $? \mathrm{~V}_{1} \mathrm{~S}$ (pronome) $+\mathrm{V}_{2} \mathrm{C}_{1}$ (sufixo) $\rightarrow$ ? $\mathrm{V}_{1} \cdot \mathrm{SV}_{2} \mathrm{C}_{1}$ (forma não-reduzida). A partir disso, a passagem à forma reduzida poderia ocorrer de duas maneiras diferentes: (I) a 
assimilação dos traços da oclusiva glotal (por exemplo, [+constricted glottis $]^{3}$ ) pela consoante soante e o apagamento de $\mathrm{V}_{1}$ ou (II) o apagamento da vogal $\mathrm{V}_{1}$, a assimilação dos traços da oclusiva glotal pela consoante soante e o apagamento da oclusiva glotal. A hipótese (I) é mais econômica, porém a assimilação ou o espalhamento dos traços da oclusiva glotal deveriam transpor $\mathrm{V}_{1}$, o que parece não ocorrer, a princípio, em outros processos fonológicos da língua Dâw. Por sua vez, o problema da hipótese (II) reside em justificar o apagamento da vogal átona $\left(\mathrm{V}_{1}\right)$ e a assimilação dos traços da oclusiva glotal pela consoante soante.

\subsection{A oclusiva glotal, as consoantes soantes e a glotalização}

Assim como a glotalização, as oclusivas glotais, que também integram o inventário fonêmico da língua Dâw (ver subseção 1.1.1), podem ter diferentes formas fonéticas. Em sua forma mais comum, não apenas na língua Dâw, mas também em outras línguas do mundo, a oclusiva glotal se manifesta acusticamente como um período de silêncio e uma transição abrupta aos segmentos adjacentes, provocada pela abertura da glote. O oscilograma da figura 58 mostra, por exemplo, o início abrupto da vogal /ã/, que se situa logo após a oclusiva glotal. Outra forma bastante frequente é a fonação rangeada intensa, que geralmente se sobrepõe à articulação oral dos segmentos próximos. Como se vê nas figuras 59 e 64, a irregularidade na duração, na amplitude e na forma de onda dos ciclos glotais é, na maioria das vezes, maior e se prolonga por mais tempo do que nas consoantes glotalizadas. Existem ainda casos, como o da figura 60, em que não se observa nem a fonação rangeada tampouco uma transição muito abrupta aos segmentos adjacentes, mas um aumento de frequência fundamental considerável e uma qualidade sonora semelhante à da voz áspera das consoantes glotalizadas.

Figura 58 - Oscilograma (A), espectrograma (B) e curva de frequência fundamental $(\mathrm{C})$ da palavra /Rãm/ pronunciada por PD
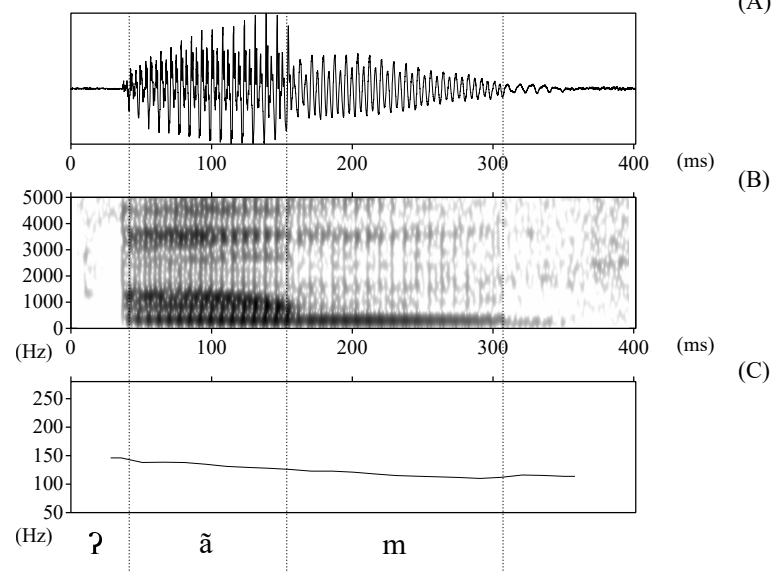

(A)

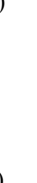

Figura 59 - Oscilograma (A), espectrograma (B) e curva de frequência fundamental (C) da palavra /?ãm/ pronunciada por NZ

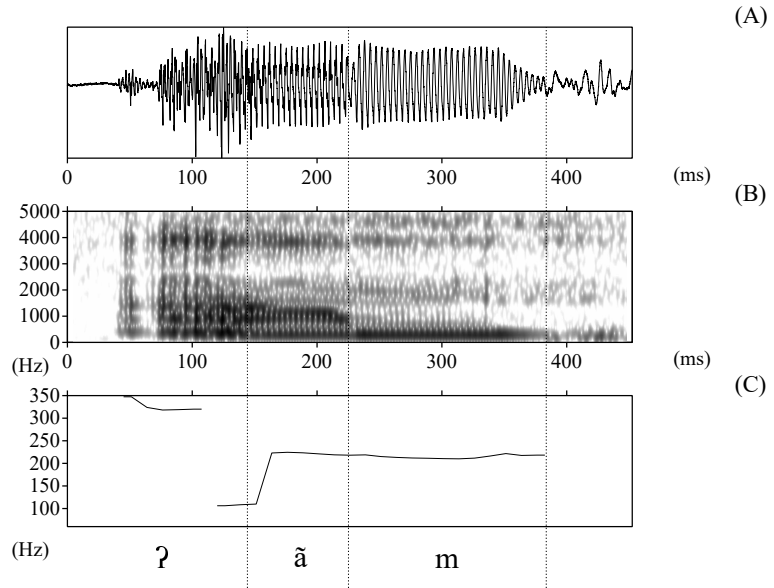

Quando se comparam as características acústicas de algumas produções da oclusiva glotal com as propriedades da glotalização (ver capítulo 4), conclui-se que há semelhanças entre a

\footnotetext{
3 Ver capítulo 3.
} 
oclusiva glotal e as consoantes glotalizadas, uma vez que ambas são produzidas com tipos de fonação e ajustes laríngeos similares. Apesar disso, notam-se claramente diferenças de duração e intensidade, que podem ser empregadas na distinção fonológica entre as consoantes glotalizadas e as consoantes afetadas por oclusivas glotais.
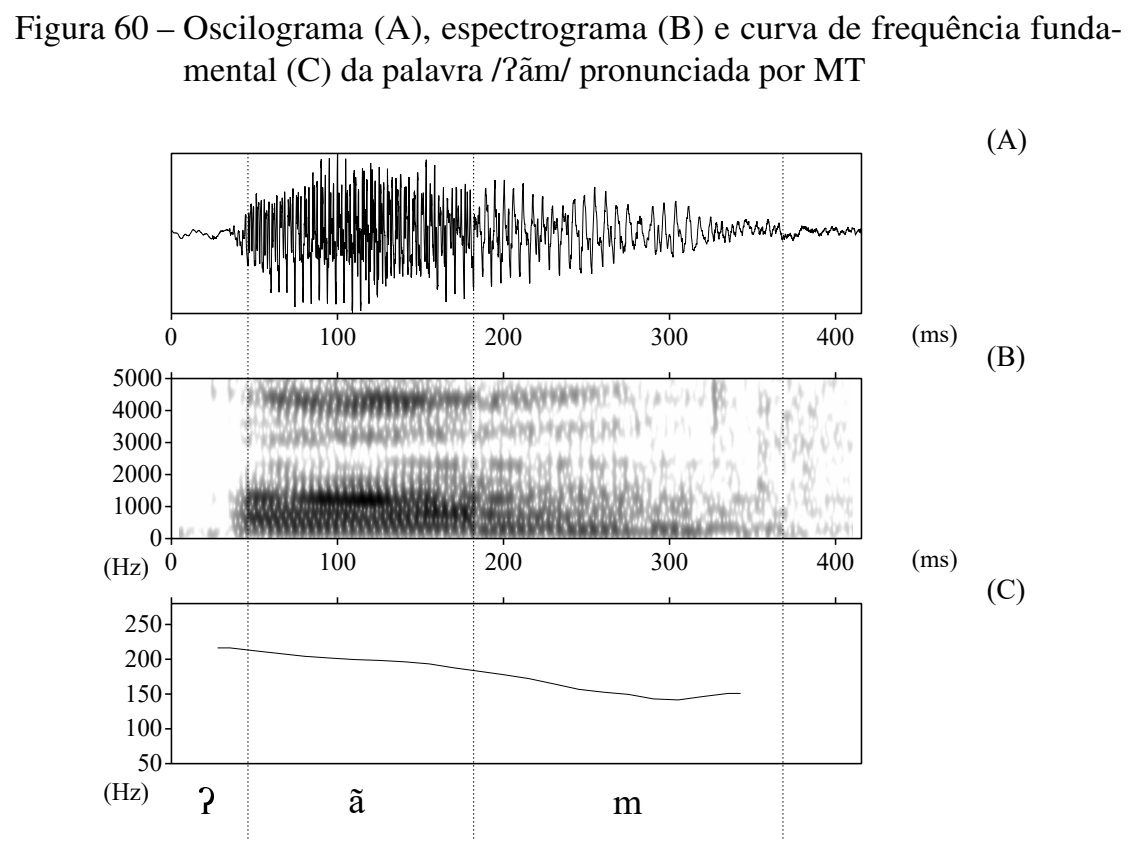
Figura 61 - Oscilograma (acima) e espectrograma (abaixo) da frase $/ \mathrm{m}^{2} \tilde{\varepsilon} \mathrm{P}$ m $\hat{\tilde{\partial}} /$ pronunciada por
VT

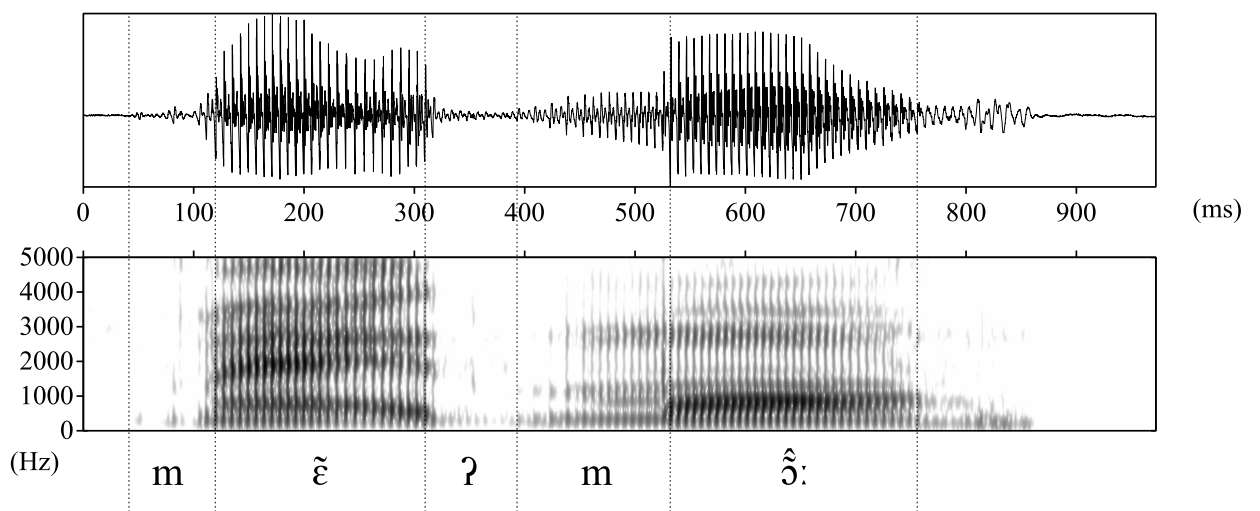

As alterações provocadas pela oclusiva glotal na fonação estendem-se, como dito, aos segmentos adjacentes. Na figura 61, a consoante /m/ da palavra /mỗ/ (“inambu”) apresenta fonação rangeada na sua parte inicial, que é decorrente da proximidade com a oclusiva glotal da palavra anterior. A consoante $/ \mathrm{m} /$ da figura 61 assemelha-se mais com a consoante $/ \mathrm{m}^{?} /$ da palavra $/ \mathrm{m}^{2} \hat{\tilde{\partial}} /$ ("irara"), pronunciada em isolamento e representada na figura 63 , do que com a consoante /m/ da palavra /mỗ/ ("inambu"), também pronunciada em isolamento e representada na figura 62 . Deste modo, é possível dizer que, quando vizinha de oclusiva glotal (se ela produz fonação rangeada, pelo menos), uma consoante simples adquire as características acústicas daquela e se torna semelhante a uma consoante glotalizada. Entretanto, a distinção entre consoantes simples 
e glotalizadas não se perde neste contexto, porque, como se observa na figura 64 , a consoante glotalizada $/ \mathrm{m}^{2} /$ possui fonação rangeada mais extensa do que a encontrada na consoante $/ \mathrm{m} / \mathrm{da}$ figura 61. Em muitos casos, além de mais extensa, a fonação rangeada também é mais intensa nas consoantes glotalizadas do que nas consoantes simples, quando ambas são vizinhas de oclusivas glotais.

As oclusivas glotais não modificam a natureza fonêmica das consoantes soantes vizinhas tampouco neutralizam a distinção entre consoantes simples e glotalizadas, mas podem produzir um efeito fonético nas consoantes soantes simples que as tornam semelhantes às consoantes soantes glotalizadas. Portanto, a hipótese (II) da seção 7.1 a respeito da transformação das consoantes simples em consoantes glotalizadas em casos de redução silábica parece ser foneticamente plausível.

Figura 62 - Oscilograma (acima) e espectrograma (abaixo) da palavra /mỗ/ pronunciada por DL

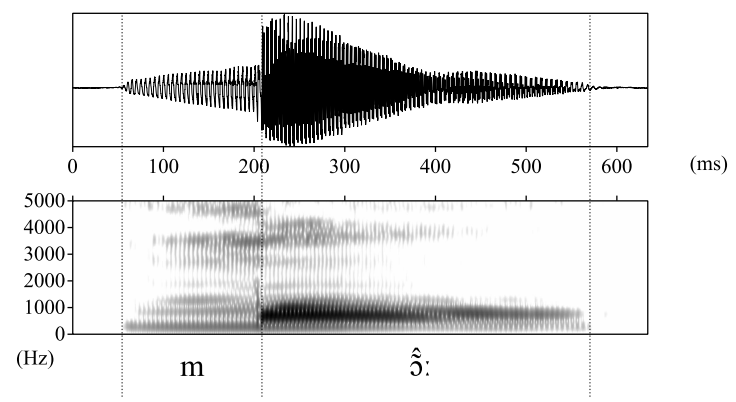

Figura 63 - Oscilograma (acima) e espectrograma (abaixo) da palavra $/ \mathrm{m}^{2} \hat{\tilde{\partial}} /$ pronunciada por DL

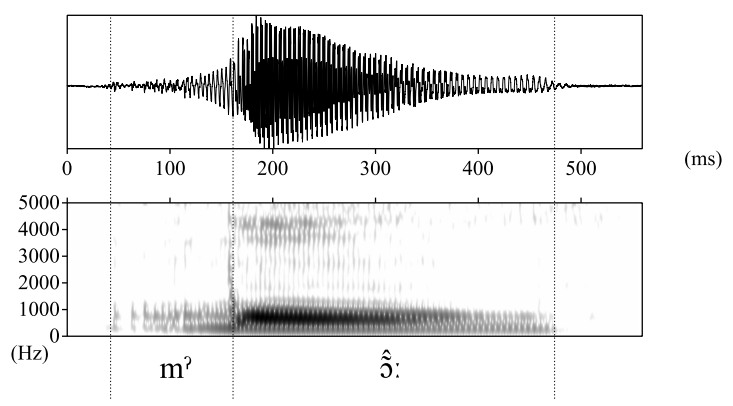

Figura 64 - Oscilograma (acima) e espectrograma (abaixo) da frase $/ \mathrm{m}^{2} \tilde{\varepsilon} \mathrm{P} \mathrm{m}^{2} \mathrm{\tilde { \tilde { \partial } }} /$ pronunciada por WD
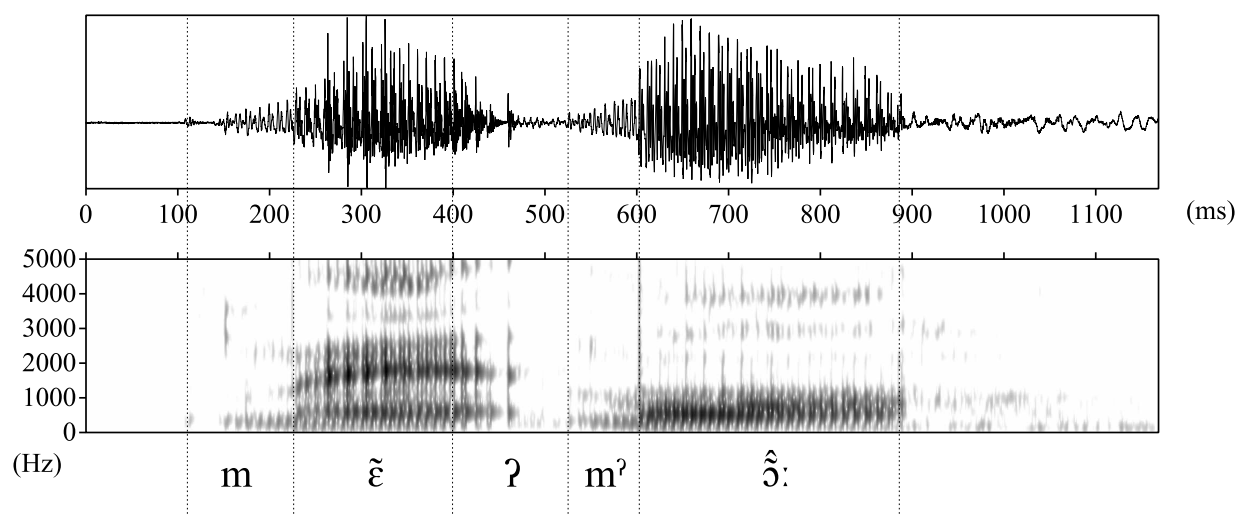

\subsection{O surgimento da glotalização}

Martins (2005) aborda o desenvolvimento histórico de vários aspectos dos sistemas fonológicos das línguas da família Nadahup, denominada por ele como Maku Oriental (ver subseção 1.1.2). Dentre os tópicos presentes no trabalho do autor mencionado, encontra-se a glotalização, que teria, segundo Martins (2005), mais de uma origem em diferentes segmentos 
e línguas. As oclusivas glotalizadas situadas em posição de ataque silábico nas palavras das línguas Hup e Yuhup teriam se originado de oclusivas ejetivas de Proto-Nadahup (MARTINS, 2005, p. 165-166). As vogais glotalizadas de Nadëb, por sua vez, teriam surgido durante o processo de perda de tom nesta língua, substituindo vogais com tom descendente encontradas em sílabas com coda desvozeada. O que mais interessa à discussão desenvolvida neste capítulo é a proposta que o autor apresenta para a origem das aproximantes glotalizadas das línguas Hup, Yuhup e Dâw.

De acordo com Martins (2005), as aproximantes glotalizadas de Hup, Yuhup e Dâw ${ }^{4}$ teriam origem no deslocamento ou "migração" da oclusiva glotal (MARTINS, 2005, p. 165). Martins (2005) sustenta que teria havido deslocamento de oclusivas glotais pertencentes (A) às sílabas precedentes ou $(\mathrm{B})$ à mesma sílaba em que se encontram os segmentos glotalizados aludidos das línguas Hup, Yuhup e Dâw (MARTINS, 2005, p. 162-165). Nos casos em que a "migração" teria ocorrido a partir das sílabas precedentes (A), dois tipos de transformação teriam se sucedido em Proto-Nadahup (MARTINS, 2005, p. 162-163):

A1. ${ }^{*} \mathrm{C}_{1} \mathrm{~V}_{1}$ ?.' $\mathrm{C}_{2} \mathrm{~V}_{2} \mathrm{C}_{3}$ (Proto-Nadahup) $\rightarrow \mathrm{C}_{1} \mathrm{~V}_{1} \cdot \mathrm{C}_{2}{ }^{2} \mathrm{~V}_{2} \mathrm{C}_{3} \rightarrow \mathrm{C}_{2}{ }^{2} \mathrm{~V}_{2} \mathrm{C}_{3}$ (Dâw, Hup e Yuhup)

A2. ${ }^{*} \mathrm{~V}_{1} \cdot{ }^{\prime} \mathrm{C}_{1} \mathrm{~V}_{2} \mathrm{C}_{2}$ (Proto-Nadahup) $\rightarrow \mathrm{C}_{1}{ }^{2} \mathrm{~V}_{2} \mathrm{C}_{2}$ (Hup, Yuhup e Dâw)

Em ambos os casos, a oclusiva glotal encontrada na primeira sílaba, precedente à sílaba acentuada, desloca-se para a última sílaba, resultando na glotalização da consoante presente no ataque desta $\left(\mathrm{C}_{2}\right.$ em $\mathrm{A} 1$ e $\mathrm{C}_{1}$ em A2). Além disso, o processo inclui a elisão da sílaba pretônica. $\mathrm{O}$ processo esquematizado em A2 é exatamente igual ao que ocorre no processo de redução silábica mostrado em (4) da seção 7.1. Este fato pode ser tomado como uma evidência importante para a hipótese de Martins (2005).

Nos casos de "migração" da oclusiva glotal dentro da mesma sílaba (B), a sílaba final CV? reduz-se para $C^{2}$ e incorpora-se à sílaba anterior (MARTINS, 2005, p. 163):

\section{B1. $\mathrm{C}_{1} \mathrm{~V}_{1} \cdot \mathrm{C}_{2} \mathrm{~V}_{2}$ ? (Proto-Nadahup) $\rightarrow \mathrm{C}_{1} \mathrm{~V}_{1} \mathrm{C}_{2}$ ? (Hup, Yuhup e Dâw)}

Apesar de a redução silábica na língua Dâw oferecer evidência positiva para a proposta de Martins (2005), há diversos problemas de inconsistência e de falta de sustentação para as protoformas. Na lista de Swadesh coligida por Epps e Bolaños (Em preparação), por exemplo, não há praticamente nenhuma evidência dos processos sugeridos por Martins (2005), ao contrário. Um número considerável de protoformas utilizadas por Martins (2005) para defender a sua proposta são reconstruídas a partir de processos pouco claros ou com pouca evidência. Entretanto, parece provável que pelo menos parte das consoantes glotalizadas da língua Dâw tenha origem na proximidade com as oclusivas glotais, como sugere o processo de redução silábica.

$\overline{4}$ Na verdade, a mesma proposta se aplica também às oclusivas glotalizadas em posição de coda silábica das palavras das língua Hup e Yuhup. 



\section{A distribuição das formas da glotalização}

Afirmou-se no capítulo 4 que a glotalização se manifesta sob diferentes formas fonéticas e que tais formas não apresentam alternância categórica, ou seja, a presença ou a ausência de uma dada forma não é condicionada por fatores linguísticos como a posição na palavra ou sílaba, o tom da sílaba (ver capítulo 6), os segmentos adjacentes etc. Apesar disso, é possível supor que algum fator favorece ou desfavorece a ocorrência de uma ou outra forma da glotalização, em vez de simplesmente determinar a sua ausência ou presença exclusiva em certos contextos. Em convergência com esse raciocínio, a seção 8.1 deste capítulo examina a relação entre a ocorrência das formas da glotalização e um fator de natureza linguística: a nasalidade. Na seção 8.2, verifica-se a distribuição das formas da glotalização entre as gravações dos participantes da pesquisa, considerando-se, especialmente, duas variáveis não-linguísticas: sexo e faixa etária.

\subsection{As formas fonéticas da glotalização e a nasalidade}

As estruturas laríngeas implicadas na glotalização, como as pregas vocais, as pregas ventriculares e o esfíncter ariepiglótico (ver capítulo 2), são relativamente independentes dos articuladores situados na cavidade oral que participam da produção das consoantes soantes da língua Dâw, como os lábios, os alvéolos, as partes anteriores da língua etc. Todas as consoantes soantes da língua Dâw, que têm pontos e modos de articulação variados, admitem a glotalização (ver capítulo 3) e, mais do que isso, qualquer uma das suas formas fonéticas. Há evidências empíricas de que não existem restrições que relacionam ponto de articulação, modo de articulação e forma de glotalização nas consoantes soantes da língua Dâw. Entretanto, as articulações que ocorrem na região da laringe e na cavidade oral interagem de outras formas: nos domínios aerodinâmico e acústico. Como não há restrições, sabe-se antecipadamente que essa interação não causa limitações severas que possam impedir a produção ou a audição de algum aspecto das consoantes glotalizadas, mas é possível supor que haja algum tipo de conflito e que, portanto, certas combinações de articulações laríngeas e supralaríngeas possam ser favorecidas.

A língua Dâw tem sete consoantes glotalizadas, que se definem por três modos de articulação (aproximante, aproximante lateral e nasal) e por quatro pontos de articulação (bilabial, alveolar, palatal e velar) ${ }^{1}$. Cada uma das consoantes se caracteriza por propriedades aerodinâmicas e

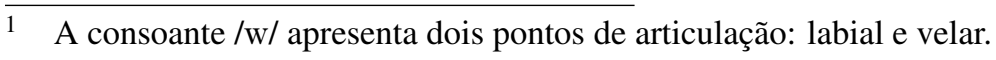


acústicas próprias. De maneira semelhante, as formas da glotalização também se diferenciam em termos aerodinâmicos e acústicos, por exemplo: quando, em alguns casos de glotalização, há oclusão glotal completa, aumenta-se a pressão subglotal e o sinal acústico é interrompido neste momento, o que não ocorre em consoantes com fonação rangeada ou com voz áspera. O cruzamento da distribuição de todas as formas da glotalização com todos as consoantes glotalizadas da língua Dâw seria uma das maneiras de verificar, de um ponto de vista empírico, se há favorecimento de certas combinações articulatórias. Como o número de gravações disponíveis é muito limitado, o cruzamento de várias categorias levaria a resultados que não teriam representatividade. No capítulo 4, agruparam-se todas as formas da glotalização em duas categorias para evitar um problema semelhante. No estudo deste capítulo, recorre-se à mesma solução: as formas da glotalização são, novamente, reduzidas a duas - com rangeado e sem rangeado - e classificam-se as consoantes da língua Dâw entre nasais e orais. As consoantes nasais assemelham-se, entre si, em diversos aspectos, como no nível de intensidade acústica, na participação da cavidade nasal (redução na pressão do ar), na localização das pistas acústicas de ponto de articulação etc. Embora haja diferenças notáveis entre, de um lado, as aproximantes /w/ $\mathrm{e} / \mathrm{j} / \mathrm{e}$, de outro lado, a aproximante lateral /1/, elas se diferenciam claramente das consoantes nasais.

Neste estudo, utilizaram-se os dados apresentados na seção 4.1, que tinham anotação não apenas das formas da glotalização, mas também das consoantes glotalizadas. Deste modo, foi necessário apenas criar uma tabela de contingência (tabela 11) com base nas categorias e nos dados considerados e submetê-la ao teste estatístico. A tabela 11 mostra que há um número maior de consoantes orais glotalizadas com rangeado (58) do que sem rangeado (39). Inversamente, há um número maior de consoantes nasais glotalizadas sem rangeado (58) do que com rangeado (42). O teste $\chi^{2}$ aponta que não há independência entre nasalidade e forma da glotalização $\left(\chi^{2}=\right.$ $6,24, \mathrm{p}=0,013)$, admitido o critério de significância $p<0,05$, com tamanho de efeito $\phi$ médio $(0,44)$.

\begin{tabular}{|c|c|c|c|}
\hline & Oral & Nasal & Total \\
\hline Com rangeado & $58(58,00 \%)$ & $42(42,00 \%)$ & $100(100,00 \%)$ \\
\hline Sem rangeado & $39(40,20 \%)$ & $58(59,80 \%)$ & $97(100,00 \%)$ \\
\hline
\end{tabular}

Se são considerados representativos, os resultados do estudo só podem ser explicados satisfatoriamente por meio de pesquisas mais amplas que integrem aspectos aerodinâmicos, acústicos e perceptuais. Pouco se sabe a respeito das características aerodinâmicas das diferentes formas da glotalização e do impacto das articulações laríngeas ou tipos de fonação nas pistas acústicas utilizadas na recuperação das informações de ponto e modo de articulação das consoantes. A principal propriedade que diferencia as consoantes glotalizadas com rangeado das consoantes 
glotalizadas sem rangeado é o nível de periodicidade, que é muito menor nas primeiras. O baixo nível de periodicidade introduz um grande número de componentes no espectro (comparar as figuras 14 e 15), o que pode encobrir picos ou declives de amplitude importantes. Em todo caso, enquanto não houver dados de uma pesquisa voltada especificamente ao tema, não é possível afirmar que o baixo nível de periodicidade causa maior interferência nas consoantes nasais do que nas consoantes orais.

\subsection{As formas fonéticas da glotalização e fatores não-linguísticos}

Uma vez que não há alternância categórica das formas da glotalização, pode-se levantar a hipótese de que existe prevalência de uma forma ou de outra na pronúncia dos diferentes falantes. A tabela 12 mostra a distribuição das consoantes glotalizadas com rangeado e sem rangeado na fala dos participantes do último trabalho de campo (ver seção 1.2). Os dados abrangem todas as palavras gravadas no trabalho de campo de 2015 que contêm consoantes glotalizadas (ver seção 1.2). Os dados do participante MT mostram-se excepcionais, porque, nas suas gravações, quase não há consoantes glotalizadas com rangeado (apenas 5). Nas gravações dos outros falantes, há proporções bastante variáveis de consoantes glotalizadas com rangeado e sem rangeado, havendo, em seis casos (DL, ES, JN, NZ, TT e VT), prevalência das primeiras e, nos cinco casos restantes (MT, PD, SL, SV e WD), prevalência das últimas.

Tabela 12 - Distribuição das formas da glotalização nas gravações dos participantes da coleta de dados de 2015

\begin{tabular}{cccccc}
\hline Identificação & Com rangeado & Sem rangeado & Total & Idade & Sexo \\
TT & 39 & 31 & 70 & abaixo dos 20 & feminino \\
ES & 79 & 49 & 128 & entre 20 e 50 & feminino \\
SL & 48 & 59 & 107 & entre 20 e 50 & feminino \\
SV & 27 & 30 & 57 & entre 20 e 50 & feminino \\
NZ & 82 & 69 & 151 & entre 20 e 50 & feminino \\
DL & 95 & 48 & 143 & acima dos 50 & feminino \\
JN & 36 & 28 & 64 & abaixo dos 20 & masculino \\
VT & 77 & 40 & 117 & abaixo dos 20 & masculino \\
MT & 5 & 93 & 98 & entre 20 e 50 & masculino \\
PD & 29 & 68 & 97 & entre 20 e 50 & masculino \\
WD & 54 & 67 & 121 & acima dos 50 & masculino \\
& & & & & \\
\hline
\end{tabular}

A tabela 12 também apresenta informações sobre faixa etária e sexo dos falantes. As faixas etárias selecionadas pretendem capturar três grupos diferentes: pessoas que ainda não entraram na fase adulta ou estão no seu início (abaixo dos 20 anos), adultos mais jovens (dos 20 aos 50 anos) e adultos mais idosos (acima dos 50 anos). A definição dos limites de cada faixa seguiu, principalmente, as características do conjunto de participantes do estudo, não havendo estudos prévios ou critérios mais sofisticados para fundamentá-la. A distribuição das ocorrências de consoantes glotalizadas com rangeado e sem rangeado de acordo com os critérios de faixa etária e sexo é apresentada, respectivamente, nas tabelas 13 e 14 . 
Tabela 13 - Distribuição das consoantes glotalizadas nas categorias de faixa etária e forma da glotalização

\begin{tabular}{lccc}
\hline & Com rangeado & Sem rangeado & Total \\
& & & \\
Abaixo dos 20 anos & $116(62,03 \%)$ & $71(37,97 \%)$ & $187(100,00 \%)$ \\
Entre 20 e 50 anos & $306(43,59 \%)$ & $396(56,41 \%)$ & $702(100,00 \%)$ \\
Acima dos 50 anos & $149(56,44 \%)$ & $115(43,56 \%)$ & $264(100,00 \%)$
\end{tabular}

Os dados da tabela 13 mostram que os falantes mais jovens (abaixo dos 20 anos) e os mais idosos (acima dos 50 anos) produzem mais consoantes glotalizadas com rangeado do que sem rangeado, enquanto os adultos jovens (entre 20 e 50 anos) pronunciam em maior quantidade as formas sem rangeado do que com rangeado. O teste $\chi^{2}$ aponta que não há independência entre as formas da glotalização e as faixas etárias do falante $\left(\chi^{2}=26,64, p<\right.$ 0,001), considerado $p<0,05$ como critério de significância, com tamanho de efeito $\phi$ grande $(0,78)$. Na tabela 14, observam-se diferenças na distribuição das consoantes glotalizadas com rangeado e sem rangeado entre os participantes do sexo feminino e do sexo masculino. Há prevalência de consoantes glotalizadas com rangeado (56\%) nas gravações dos participantes do sexo feminino e de consoantes glotalizadas sem rangeado (60\%) nas gravações dos participantes do sexo masculino. O teste $\chi^{2}$ confirma, mais uma vez, que não há independência entre as formas da glotalização e os sexos dos falantes $\left(\chi^{2}=28,81, p<0,001\right)$, sendo o critério de significância $p<0,05$, com tamanho de efeito $\phi$ grande $(0,85)$.

Tabela 14 - Distribuição das consoantes glotalizadas nas categorias de sexo e forma da glotalização

\begin{tabular}{lccc}
\hline & Com rangeado & Sem rangeado & Total \\
Masculino & $201(40,44 \%)$ & $296(59,56 \%)$ & $497(100,00 \%)$ \\
Feminino & $370(56,40 \%)$ & $286(43,60 \%)$ & $656(100,00 \%)$
\end{tabular}

Embora tenham sido encontradas relações estatísticas entre as ocorrências das formas da glotalização e dois fatores não-linguísticos - faixa etária e sexo -, a interpretação dos resultados deve ser feita de maneira cuidadosa. A distribuição das formas da glotalização entre os falantes de diferentes faixas etárias não indica mudança em curso, porque tanto os falantes mais jovens (abaixo dos 20 anos) quanto os falantes mais idosos (acima dos 20 anos) produzem em maior quantidade consoantes glotalizadas com rangeado. Apenas uma pesquisa de natureza sociolinguística, feita com um número maior de falantes, grupos mais balanceados e critérios mais bem desenvolvidos, poderia verificar se os resultados são realmente representativos e tentar explicá-los. De qualquer maneira, os dois estudos deste capítulo permitem vislumbrar alguns fatores que provavelmente influenciam as ocorrências das formas da glotalização. 


\section{Considerações finais}

Em conformidade com a descrição de Martins (2004), este trabalho confirma que a glotalização é uma propriedade distintiva das consoantes soantes da língua Dâw (ver capítulo 3). A pesquisa demonstra também que, no inventário fonológico da língua Dâw, existe uma consoante glotalizada para cada consoante simples da classe das soantes, o que inclui a consoante nasal, velar e glotalizada $\left(\mathrm{y}^{2}\right)$, que não havia sido relatada por Martins (2004). Na perspectiva da fonologia, a glotalização pode ser compreendida de várias maneiras, como a presença do traço [+constricted glottis] ou [+cet] ou, ainda, de um gesto laríngeo caracterizado por um nível maior de constrição. O processo de redução silábica (ver capítulo 7) oferece evidências de que as consoantes glotalizadas e a oclusiva glotal, também presente no sistema fonológico da língua Dâw, compartilham o mesmo traço, o que é reforçado pela descrição fonética (ver capítulo 4 e seção 7.2). A compreensão mais apurada da natureza fonológica demanda, contudo, um estudo destinado exclusivamente ao tema.

No capítulo 4, observou-se que a glotalização se manifesta sob diferentes formas fonéticas na língua Dâw. Verificaram-se, em níveis variados, fonação rangeada, voz áspera (ver capítulo 2), oclusão glotal ou até mesmo a combinação de mais de uma dela. Talvez se encontre a mesma situação em muitas outras línguas que têm segmentos denominados glotalizados ou laringaliza$\operatorname{dos}^{2}$, mas os linguistas não distinguiram as diferentes formas ou simplificaram a descrição por razões práticas. A despeito das diferenças, verificou-se no capítulo 4 que todas as formas das consoantes glotalizadas compartilham algumas propriedades - redução de duração, periodicidade e $\mathrm{H} 1-\mathrm{H} 2$ - que as diferenciam das consoantes simples. O capítulo 8 mostrou que as formas da glotalização se distribuem de maneira diferente de acordo com o sexo e a faixa etária dos falantes. Porém, não há razões para sustentar que haja um processo de mudança em curso, uma vez que os falantes mais jovens e os falantes mais velhos apresentam em sua fala distribuições semelhantes das formas da glotalização.

O estudo do capítulo 5 confirmou que algumas propriedades da glotalização se concentram nas regiões das consoantes mais distantes das vogais vizinhas. Na literatura, há registros do mesmo padrão em outras línguas, sem relação de parentesco entre si e com a língua Dâw, que têm consoantes soantes glotalizadas (PLAUCHÉ et al., 1998). Esta pesquisa não pôde se debruçar sobre a motivação do fato observado. Vislumbram-se explicações de ordem perceptual e diacrônica. Embora o processo de redução silábica (ver capítulo 7) reforce a possibilidade de explicação diacrônica, não há dados suficientes para defender o surgimento das consoantes soantes glotalizadas a partir da incorporação de traços ou gestos de oclusivas glotais. Por outro lado, a distribuição das formas da glotalização entre consoantes orais e nasais (ver seção 8.1)

2 Gerfen e Baker (2005), por exemplo, mencionam a variabilidade fonética das vogais laringalizadas da língua Coatzospan Mixtec, que podem ser pronunciadas não apenas com fonação rangeada, mas também como formas mais sutis que afetam os níveis de intensidade acústica e frequência fundamental. 
sugere a influência de fatores de percepção na manifestação fonética da glotalização.

Ainda no capítulo 5, viu-se que as consoantes glotalizadas provocam aumento nos níveis de frequência fundamental em algumas partes das vogais vizinhas. Como a língua Dâw possui um sistema tonal (ver subseção 1.1.1), o capítulo 6 investigou a interação desses dois aspectos do sistema fonológico que alteram a frequência fundamental. O resultado das análises indicou que os níveis de frequência fundamental relacionados com o sistema tonal são priorizados, de tal maneira que, quando há possibilidade de conflito, as alterações causadas pelas consoantes glotalizadas desaparecem ou deslocam-se.

A pesquisa tratou de vários aspectos das consoantes glotalizadas da língua Dâw, enfocando, especialmente, as suas características fonéticas. Os resultados dos estudos compreendidos neste trabalho trouxeram novas informações sobre a glotalização na língua Dâw e podem contribuir para estudos semelhantes em outras línguas, estudos gerais das articulações laríngeas e dos tipos de fonação e estudos genéticos e areais. Algumas questões não puderam ser completamente solucionadas, como a natureza fonológica da glotalização, a motivação do padrão temporal da glotalização e da distribuição das suas formas de acordo com alguns fatores linguísticos e não-linguísticos. Apesar disso, as informações presentes neste trabalho e a formulação dos problemas colocam as questões mencionadas no horizonte dos estudos sobre a língua Dâw. 


\section{Referências}

AIKHENVALD, A. The languages of the Amazon. Oxford: Oxford University Press, 2012.

ANDRADE, W. A nasalização na língua Dâw. Dissertação (Mestrado) — Universidade de São Paulo, São Paulo, 2014.

ASHBY, M.; PRZEDLACKA, J. Measuring incompleteness: acoustic correlates of glottal articulations. Journal of International Phonetic Association, v. 44, n. 3, p. 283-296, dez. 2014.

ASSIS, L. Da cachaça à libertação: Mudanças nos hábitos de beber do povo Dâw no Alto Rio Negro. Revista Antropos, v. 1, n. 1, nov. 2007.

BARBOSA, J. Descrição fonológica da língua Nadëb. Dissertação (Mestrado) — Universidade de Brasília, Brasília, 2005.

BLANKENSHIP, B. The time course of breathiness and laryngealization in vowels. Tese (Doutorado) - UCLA, Los Angeles, 1997.

BOERSMA, P.; WEENINK, D. Accurate short-term analysis of the fundamental frequency and the harmonics-to-noise ratio of a sampled sound. In: Proceedings of the Institute of Phonetic Sciences 17. Amsterdam: University of Amsterdam, 1993. p. 97-110.

BROWMAN, C.; GOLDSTEIN, L. Articulatory Phonology: an overview. Haskins Laboratories Status Report on Speech Research, p. 23-42, 1992.

CARVALHO, M. Aspecto verbal na língua Dâw. Dissertação (Mestrado) - Universidade de São Paulo, São Paulo, 2016.

CATFORD, J. Phonation types: The classification of some laryngeal components of speech production. In: ABERCROMBIE, D. et al. (Ed.). In honor of Daniel Jones. London: Longmans, 1964. p. 26-37.

COSTA, J. A estrutura argumental da língua Dâw. Dissertação (Mestrado) - Universidade de São Paulo, São Paulo, 2014.

EDMONDSON, J.; ESLING, J. The valves of the throat and their functioning in tone, vocal register and stress: laryngoscopic case studies. Phonology, v. 23, n. 2, p. 157-191, ago. 2006.

EPPS, P. A Grammar of Hup. Tese (Doutorado) - University of Virginia, Charlottesville, 2005.

EPPS, P.; BOLAÑOS, K. Reconsidering the "Makú" family of northwest Amazonia. Em preparação.

ESLING, J.; FRASER, K.; HARRIS, J. Glottal stop, glottalized resonants, and pharyngeals: a reinterpretation with evidence from a laryngoscopic study of Nuuchahnulth (Nootka). Journal of Phonetics, v. 33, n. 4, p. 383-410, 2005.

ESLING, J.; HARRIS, J. An expanded taxonomy of states of the glottis. In: ICPHS, 15., 2003, Barcelona. Barcelona, 2003. p. 1049-1052.

GERFEN, C.; BAKER, K. The production and perception of laryngealized vowels in coatzospan mixtec. Journal of Phonetics, v. 33, n. 3, p. 311-334, jul. 2005. 
GORDON, M. A typology of contour tone restrictions. Studies in Language, v. 25, n. 3, p. 423-462, 2001.

GORDON, M.; LADEFOGED, P. Phonation types: a cross-linguistic overview. Journal of Phonetics, v. 29, n. 4, p. 383-406, out. 2001.

HALL, T. Segmental features. In: LACY, P. de (Ed.). The Cambridge Handbook of Phonology. Cambridge: Cambridge University Press, 2007. p. 311-334.

HALLE, M.; STEVES, K. A note on laryngeal features. Quarterly Progress Report 101, MIT, 1971.

HOLLIEN, H.; MICHEL, J. Vocal fry as a phonation register. Journal of Speech, Language, and Hearing Research, v. 11, n. 3, p. 600-604, set. 1968.

HOLLIEN, H. et al. On the nature of vocal fry. Journal of Speech, Language, and Hearing Research, v. 9, n. 2, p. 245-247, jun. 1966.

KINGSTON, J. The phonetics and phonology of the timming of oral and glottal events. Tese (Doutorado) - University of California, Berkeley, 1985.

LADEFOGED, P.; MADDIESON, I. The Sounds of the World's Languages. Cambridge: Blackwell, 1996.

LAVER, J. The phonetic description of voice quality. Cambridge: Cambridge University Press, 1980.

LAVER, J. Principles of phonetics. Cambridge: Cambridge University Press, 1994.

LOPES, A. Fonologia da língua Yuhup: uma abordagem não-linear. Dissertação (Mestrado) Universidade Federal de Santa Catarina, Florianópolis, 1995.

LOPES, A.; PARKER, S. Aspects of Yuhup phonology. International Journal of American Linguistics, v. 65, n. 3, p. 324-342, jul. 1999.

MARTINS, S. Fonologia e Gramática Dâw. Amsterdam: LOT Publications, 2004.

MARTINS, V. Reconstrução fonológica do Protomaku Oriental. Amsterdam: LOT Publications, 2005.

MOISIK, S.; ESLING, J. The 'whole larynx' approach to laryngeal features. In: ICPHS, $17 .$, 2011, Hong Kong. Hong Kong, 2011. p. 1406-1409.

NÍ, A.; GOBL, C. Voice source variation. In: HARDCASTLE, W.; LAVER, J. (Ed.). The Handbook of Phonetic Sciences. Oxford: Blackwell Publishing, 1999. p. 427-462.

ORJUELA, L. Fenômenos de glotalização-laringalização em três línguas Tukano Oriental, fronteira Colômbia-Brasil: Tuyuka, Tukano e Makuna. Dissertação (Mestrado) - Universidade de São Paulo, São Paulo, 2014.

PLAUCHÉ, M. et al. Glottalized sonorants: a phonetic universal? In: Twenty-Fourth Annual Meeting of the Berkeley Linguistics Society. Berkeley: University of Berkeley, 1998. p. 97-110.

ROACH, P. Laryngeal/oral coarticulation in glottalized english plosives. Journal of International Phonetic Association, v. 9, p. 2-6, jun. 1979. 
SILVERMAN, D. Phasing and recoverability. New York e London: Garland Publishing, 1997.

STENZEL, K. Multilingualism in the Northwest Amazon, revisited. In: Memorias del Congreso de Idiomas Indígenas de Latinoamérica-II. Austin: University of Texas at Austin, 2005.

STENZEL, K. Glottalization and other suprasegmental features in Wanano. IJAL, v. 73, n. 3, p. 331-366, jul. 2007.

STERIADE, D. Phonetics in phonology: the case of laryngeal neutralization. Manuscrito. 1997. 

Apêndices 



\section{$\mathbf{A}$}

Apresentação da pesquisa à comunidade Dâw 


\title{
Aspectos da glotalização na língua Dâw Um estudo de fonética experimental
}

\author{
Lucas Cavalini Barboza [lucas.cavalini.barboza@usp.br] \\ Orientadora: Prof. ${ }^{\text {a }}$ Dr. ${ }^{\text {a Luciana Raccanello Storto }}$
}

A minha pesquisa de mestrado pertence a uma área dos estudos da linguagem e da fala conhecida por fonética. Uma das principais ocupações da fonética é a descrição e classificação dos sons que existem nas línguas do mundo. Em meu trabalho, estudo uma parte muito interessante do conjunto de sons da língua Dâw: a glotalização. A glotalização desempenha um papel importante na língua porque é um meio de diferenciação de palavras [ler o terceiro parágrafo]. Nos parágrafos seguintes, discuto, de maneira resumida, a glotalização e a minha pesquisa.

Classificamos os sons das línguas de acordo com a sua forma de produção (ou articulação). Existem sons, as oclusivas, que são produzidos com a obstrução plena (bloqueio) de algum ponto do trato vocal [ver quadro ao lado], por exemplo: a elevação da ponta da língua até o céu da boca ou o contato dos lábios. Em Dâw, existem as seguintes oclusivas: $p, t, c ̧, k$, ', b, d, j e g. Na execução de outros sons, as partes móveis do trato vocal (por exemplo, os lábios e a língua) não o obstruem completamente. Alguns destes sons, as fricativas, são ruidosos, porque as partes móveis se aproximam muito de um ponto do trato vocal. A língua Dâw conta com três fricativas: s, x e r. Outros sons, as soantes, não são ruidosos e apresentam grande variedade na forma como são gerados. As soantes da língua Dâw são: w, y, m, n, nh, gn e l. Tais sons existem também na língua portuguesa, porém, em Dâw, eles têm duas formas: simples e glotalizada.

Algumas estruturas contidas na garganta - a laringe, a faringe e a epiglote participam, sob diferentes formas, da produção da fala. Em português, existem sons desvozeados e vozeados, por exemplo: pata e bata, tela e dela, coma e goma, foz e voz etc. Em cada par de palavra, a única diferença é o desvozeamento, na primeira palavra, (p, t, c e f) e o vozeamento, na segunda palavra, (b, d, g e v) da primeira consoante. Do ponto de vista da produção da fala, o vozeamento consiste na vibração das pregas vocais, que se situam na laringe. Em sons desvozeados, as pregas vocais permanecem afastadas e não vibram. Na língua Dâw, como em todas as línguas, há também sons desvozeados e vozeados, por exemplo: pa' (paca, em português) e ba' (frio, em português), taáp (pessoa negra, em português) e daáp (nome de um igarapé), kig (separar briga, em português) e gid (quando, em português) etc. Contudo, a língua Dâw possui outro tipo de distinção, que se aplica apenas às soantes: simples e glotalizada. A representação ortográfica da glotalização, para a língua Dâw, é o apóstrofo ('). Em w'ây (palavra, em português), por exemplo, o apóstrofo indica que a soante w é glotalizada. A troca de uma soante simples por uma glotalizada (e vice-versa) pode alterar o significado da palavra, como em lon (sapo, em português) e lon' (recolher linha de pesca, em português), lay (formiga, em português) e laay' (anzol, em português), waam (macaco cutiporó, em português) e waám' (embaúba, em português).

Baseado nas descrições e nos debates da fonética sobre o tema, no extenso trabalho de Silvana Martins (Fonologia e Gramática Dâw) e em minhas próprias observações, compreendo a glotalização na língua Dâw como um conjunto de movimentos de estruturas da laringe que causa maior obstrução nessa região do trato vocal [ver quadro ao lado]. O meu material de estudo consistiu em várias gravações, tornadas possíveis graças à paciência e à boa disposição de membros da comunidade Dâw, de palavras que contêm soantes glotalizadas. Notei que há mais de uma forma de glotalização na língua Dâw e, então, as classifiquei por meio da audição atenta das gravações e de algumas ferramentas essenciais da análise fonética: o oscilograma, o espectrograma e o espectro FFT [ver quadro ao lado]. Os dois tipos de glotalização mais expressivos são a fonação rangeada e a voz áspera [ver quadro ao lado], que, embora sejam claramente diferentes, têm muitas semelhanças. Observei diversas características acústicas [ver quadro ao lado] das soantes glotalizadas, comparando-as às soantes simples, a fim de descrevê-las com mais detalhes. Conforme se esperava, as soantes glotalizadas apresentaram algumas propriedades acústicas diferentes das soantes modais e notei apenas pequenas divergências entre os diferentes tipos de glotalização [ver tabela A]. Para verificar as medidas, utilizei um teste estatístico chamado teste t pareado, que, por meio de fórmulas matemáticas, mostra a chance (probabilidade) de as medidas serem realmente diferentes. Nas tabelas de 1 a 10 , consta a descrição estatística das características estudadas (média é o valor comparado no teste estatístico). As observações até então feitas devem ser confirmadas e ampliadas por meio da análise de uma quantidade maior de gravações. Para entender a relevância das características encontradas e outros aspectos do tema, pretendo realizar um teste de percepção [ver quadro ao lado]. Haverá também necessidade de coletar dados de natureza articulatória [ver quadro ao lado], que podem revelar algumas informações sobre como a glotalização é realmente produzida.

\section{Trato vocal}

Parte do corpo envolvida diretamente na produção da fala do nível da laringe até os lábios e até as narinas. [Clique aqui para ver a imagem]

\section{Soantes}

Sons consonantais produzidos com menor obstrução no trato vocal. Na língua Dâw, são representados pelos símbolos: $\mathrm{w}, \mathrm{y}, \mathrm{m}, \mathrm{n}, \mathrm{nh}$, gn e $\mathrm{l}$.

\section{Vozeamento}

Consiste na vibração da pregas vocais, que são estruturas situadas na laringe.

\section{Glotalização}

Conjunto de movimentos de estruturas da laringe que causa maior obstrução nessa região do trato vocal. Em Dâw, apenas as soantes podem (ou seja, as oclusivas, as fricativas e as vogais não podem) ser simples ou glotalizadas. A glotalização participa do sistema de distinções de significado, ou seja, se uma soante simples (não-glotalizada) for substuída por uma soante glotalizada (ou vice-versa), o significado da palavra pode ser alterado.

\section{Fonética acústica}

Ramo da fonética que estuda os sons das línguas por meio da física acústica. $\mathrm{O}$ estudo da fonética acústica inclui descrições e medidas. Há muitas ferramentas à disposição da fonética acústica, como o oscilograma, o espectrograma e o espectro FFT. [Clique aqui para ver a imagem]

\section{Fonética articulatória}

Ramo da fonética que estuda a produção dos sons das línguas. Existem diferentes métodos, da captura de imagem a meios mais indiretos.

\section{Teste de percepção}

Os falantes de uma língua identificam ou descriminam sons alterados pelo pesquisador. Desta maneira, o pesquisador pode entender como as características físicas influenciam na percepção de um som.

\section{Fonação rangeada}

Modo de vibração das pregas vocais lento e irregular. O som resultante é muito característico, assemelha-se ao ruído provocado por um bastão correndo sobre um trilho.[Clique aqui para ouvir um exemplo]

\section{Voz áspera}

As pregas vocais encontram-se tensionadas e, assim, é produzido um som áspero e alto (agudo), como se 
Tabela A - Comparação das características acústicas das soantes glotalizadas em relação às das soantes simples [ver quadro ao lado]

\section{Duração}

Frequência fundamental

Intensidade acústica

$\mathrm{H} 1-\mathrm{H} 2$

Frequência de F1
Fonação Rangeada

\section{Menor}

Menor

Menor

Menor

Maior

Voz áspera
Menor
Maior
Menor
Menor
Maior

Tabela 1-10 - Descrição estatística das medidas acústicas [ver quadro ao lado]
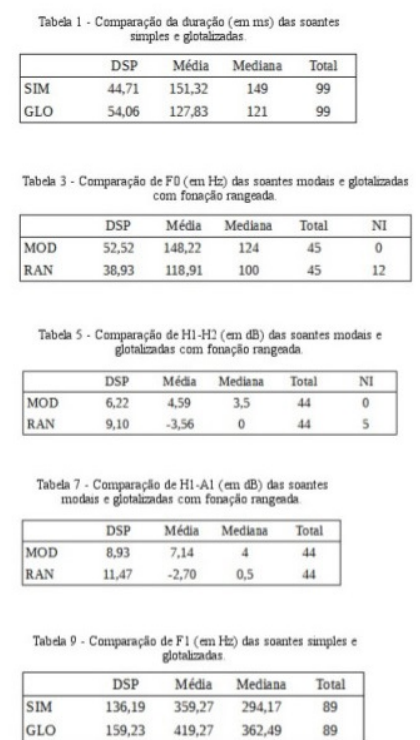

Abreviaçōes

SIM soantes simples

GLO soantes glotaliadas
MOD soantes modais (simples)

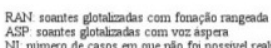

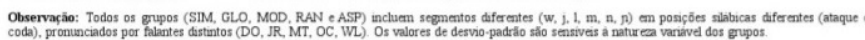
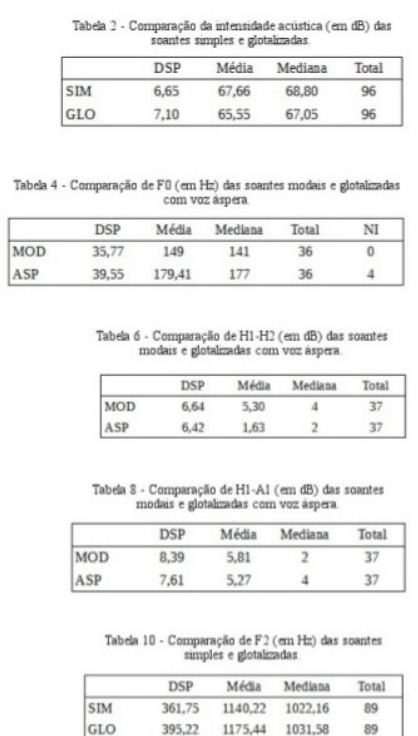

SIM

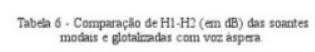

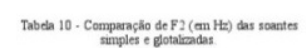

$$
\text { DSP. desvo-padra }
$$

houvesse pressão dentro da garganta. [Clique aqui para ouvir um exemplo]

\section{Características acústicas}

* Frequência fundamental (F0): taxa de vibração das pregas vocais, quanto maior, mais agudo o som, quanto menor, mais grave

* Intensidade acústica: quanto maior, mais forte é o som

* H1-H2: medida de espectro FFT.

* H1-A1: medida de espectro FFT.

* Frequência de F1: medida de espectrograma.

* Frequência de F2: medida de espectrograma.

Em outras línguas do mundo, como as línguas Otomangues do México, as língua Sino-tibetanas da China e as línguas Tucano da Colômbia, existe algo semelhante à glotalização da língua Dâw. No entanto, trata-se ainda de um tipo de som relativamente incomum e que exige maior compreensão. O estudo desse aspecto fascinante da língua Dâw pode fornecer informações valiosas à fonética, contribuindo, em alguma medida, para o entendimento da laringe como um articulador.

\section{Apoio:}

\section{@CNPq}

Processo FAPESP no 2014/26712-0, Fundação de Amparo à Pesquisa do Estado de São Paulo (FAPESP).

As opiniões, hipóteses e conclusões ou recomendações expressas neste material são de responsabilidade do autor e não necessariamente refletem a visão da FAPESP. 